WSRC-TR-2001-00051, Revision 0

\title{
SLUDGE BATCH 2 (MACROBATCH 3) RHEOLOGY STUDIES WITH SIMULANTS (U)
}

\section{C. KOOPMAN}

Westinghouse Savannah River Company

Savannah River Site

Aiken, SC 29808

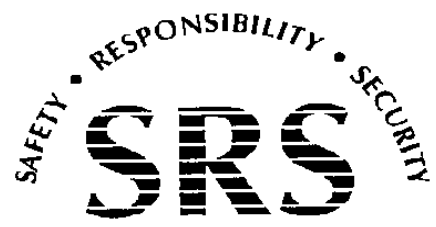

PREPARED FOR THE U.S. DEPARTMENT OF ENERGY UNDER CONTRACT NO. DE-AC09-96SR18500 
This document was prepared in conjunction with work accomplished under Contract No.

DE-AC09-96SR18500 with the U.S. Department of Energy.

\section{DISCLAIMER}

This report was prepared as an account of work sponsored by an agency of the United States Government. Neither the United States Government nor any agency thereof, nor any of their employees, makes any warranty, express or implied, or assumes any legal liability or responsibility for the accuracy, completeness, or usefulness of any information, apparatus, product or process disclosed, or represents that its use would not infringe privately owned rights. Reference herein to any specific commercial product, process or service by trade name, trademark, manufacturer, or otherwise does not necessarily constitute or imply its endorsement, recommendation, or favoring by the United States Government or any agency

thereof. The views and opinions of authors expressed herein do not necessarily state or reflect those of the United States Government or any agency thereof.

This report has been reproduced directly from the best available copy.

Available for sale to the public, in paper, from: U.S. Department of Commerce, National Technical Information Service, 5285 Port Royal Road, Springfield, VA 22161, phone: (800)

553-6847, fax: (703) 605-6900, email: orders@ntis.fedworld.gov online ordering: http://www.ntis.gov/ordering.htm

Available electronically at http://www.doe.gov/bridge

Available for a processing fee to U.S. Department of Energy and its contractors, in paper, from: U.S. Department of Energy, Office of Scientific and Technical Information, P.O. Box 62, Oak Ridge, TN 37831-0062, phone: (865 ) 576-8401, fax: (865) 576-5728, email: reports@ adonis.osti.gov 
WSRC-TR-2001-00051, Revision 0

Keywords: DWPF, CPC, Sludge, Tank 42, Tank 8, Tank 40, Sludge Batch 2, Macrobatch 3, SRAT, SME, Rheology

Retention: Permanent

\section{SLUDGE BATCH 2 (MACROBATCH 3) RHEOLOGY STUDIES WITH SIMULANTS (U)}

D. C. Koopman

Publication Date: February 23, 2001

Westinghouse Savannah River Company

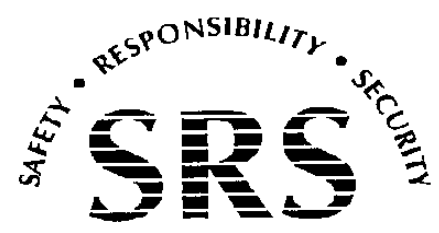

SAVANNAH RIVER SITE

PREPARED FOR THE U.S. DEPARTMENT OF ENERGY UNDER CONTRACT NO. DE-AC09-96SR18500 


\section{APPROVALS}

D. C. Koopman, Author

T. L. Fellinger, Technical Reviewer

S. L. Marra, Manager

E. W. Holtzscheiter, Manager, Immobilization Technology
Date

Date

Date

Date 
WSRC-TR-2001-00051

Page $\mathrm{v}$

\section{TABLE OF CONTENTS}

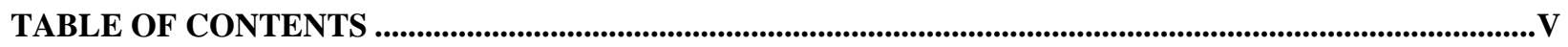

LIST OF FIGURES .............................................................................................................................................................. VI

LIST OF TABLES ............................................................................................................................................................ VI

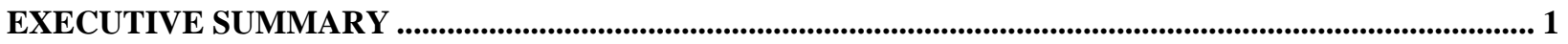

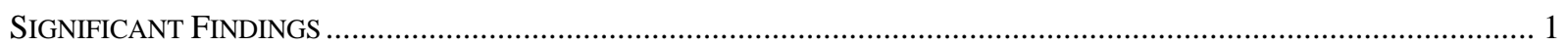

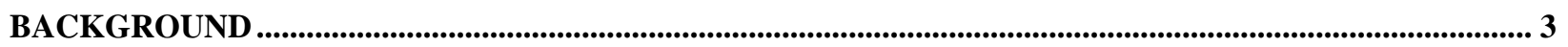

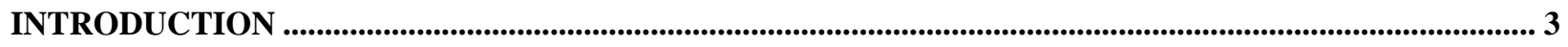

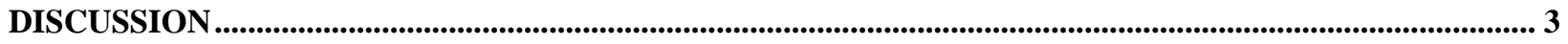

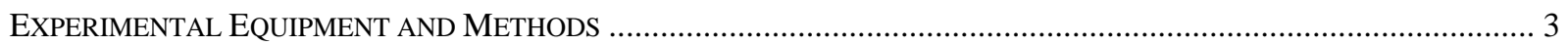

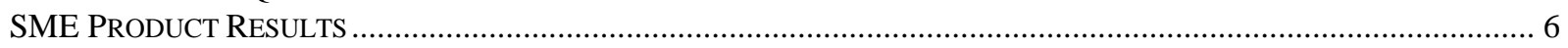

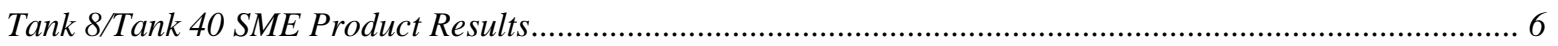

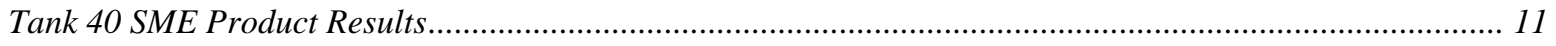

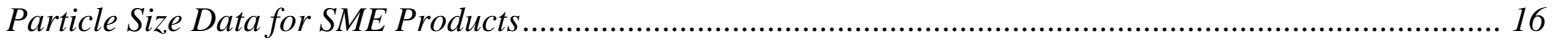

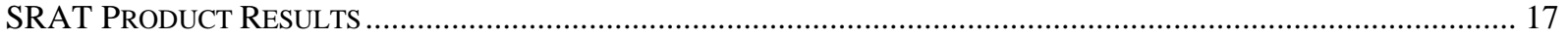

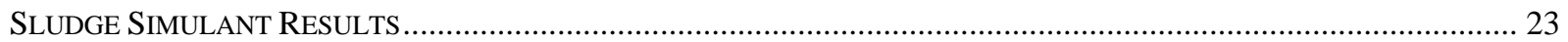

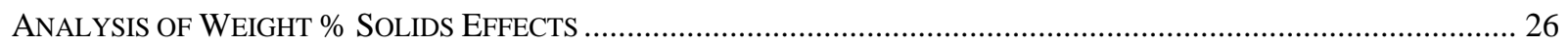

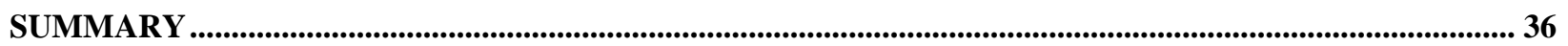

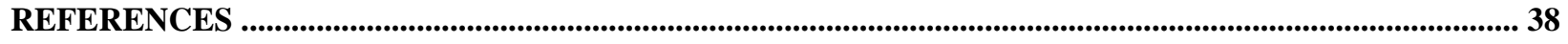

APPENDIX I: PARTICLE SIZE DISTRIBUTION RESULTS ............................................................................ 39 


\section{LIST OF FIGURES}

Figure 1. Tank 8/Tank 40 SME Product Containing HM Levels of Noble Metals at $25^{\circ} \mathrm{C} \ldots \ldots \ldots . . .8$

Figure 2. Nominal Tank 8/Tank 40 SME Product Flow Curves at $25^{\circ} \mathrm{C}$....................................

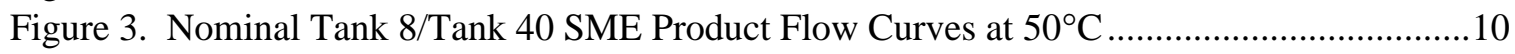

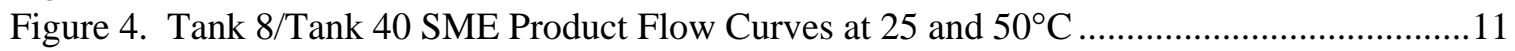

Figure 5. Tank $40 \mathrm{SME}$ Product Flow Curves at $25^{\circ} \mathrm{C}$..........................................................13

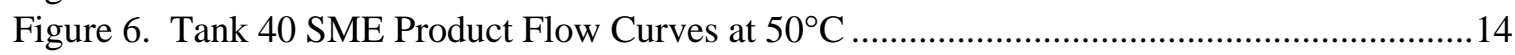

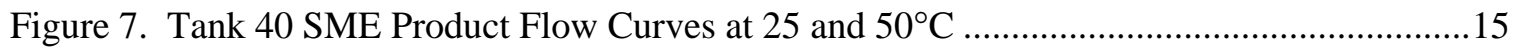

Figure 8. Entire Flow Curve Data for Two Tank 40 SME Products at $50^{\circ} \mathrm{C}$...............................16

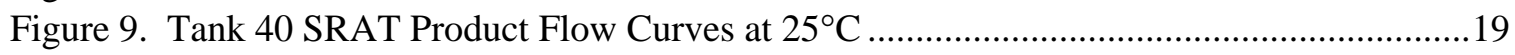

Figure 10. Effect of Acid Stoichiometry on SRAT Product Rheology ........................................21

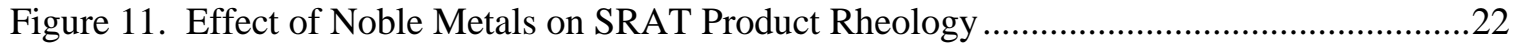

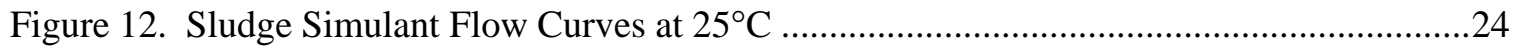

Figure 13. Comparison of Predicted to Measured Flow Curves for Blended Sludge ...................26

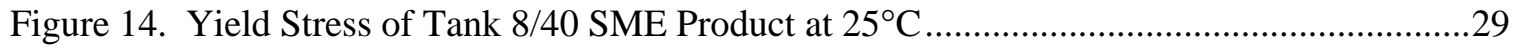

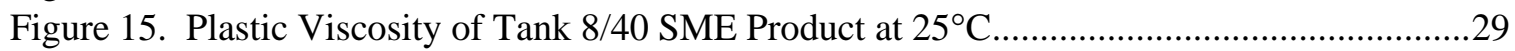

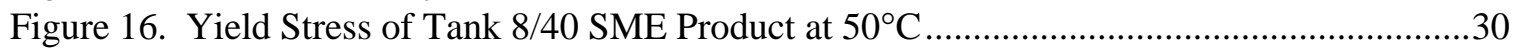

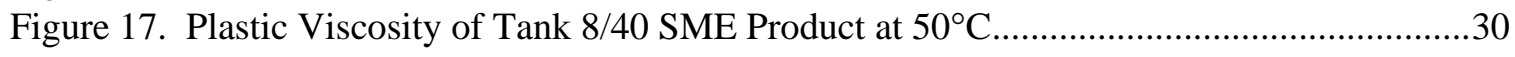

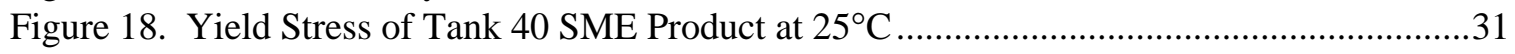

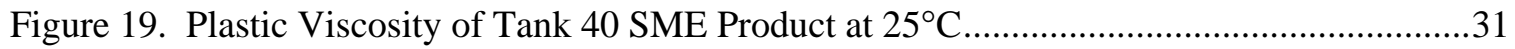

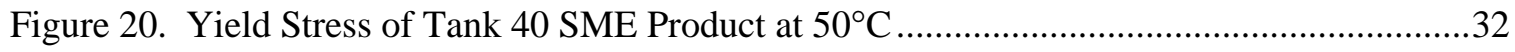

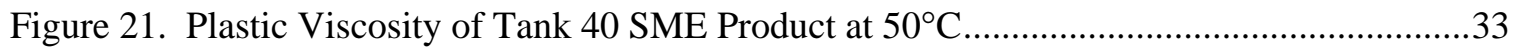

Figure 22. Comparison of Typical Tank 40 and Tank 8/40 SME Product Flow Curves ..............34

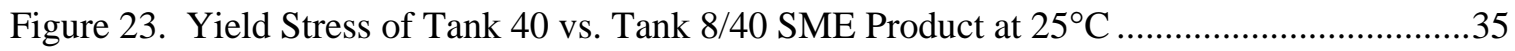

Figure 24. Plastic Viscosity of Tank 40 vs. Tank 8/40 SME Product at $25^{\circ} \mathrm{C}$..............................35

Figure 25. Yield Stress of Tank 40 vs. Tank 8/40 SME Product at $50^{\circ} \mathrm{C}$...................................36

Figure 26. Plastic Viscosity of Tank 40 vs. Tank 8/40 SME Product at $50^{\circ} \mathrm{C}$...............................36

Figure 27. Composite Tank 8/40 Blend Particle Size Distributions .............................................51

Figure 28. Worst Case Tank 8/40 Blend Particle Size Distributions .........................................52

Figure 29. Mn and Ni Trimmed Tank 40 Particle Size Distribution Data ...................................53

\section{LIST OF TABLES}

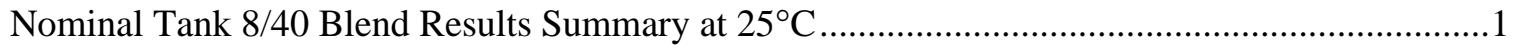

Table 1. Summary of Tank 8/40 Blend SME Product Results .....................................................

Table 2. Summary of Tank 40 SME Product Results.................................................................12

Table 3. Summary of Particle Size Data for SME Products from Process Simulations................17

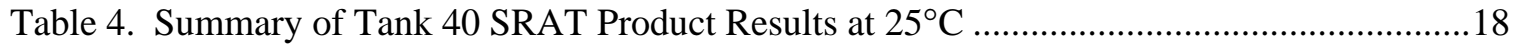

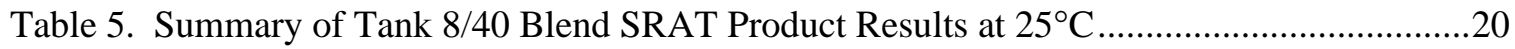

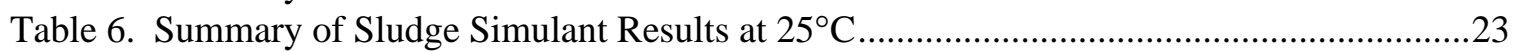

Table 7. Parameters Governing Dependence on Wt. \% Insoluble Solids .....................................27

Table 8. Historical Parameters Fitting the Bingham Fluid Properties of SME Products ..............28 
WSRC-TR-2001-00051

Page 1 of 53

\section{EXECUTIVE SUMMARY}

Non-radioactive sludge-only process simulations of the DWPF Sludge Receipt and Adjustment Tank (SRAT) and the Slurry Mix Evaporator (SME) cycles were conducted for a 50:50 blend of Tank 8 and Tank 40 washed sludge and Tank 40 washed sludge by itself. These bounding-case simulations were completed in 772-T prior to the successful transfer of Tank 8 into Tank 40.

Sludge processing results were documented previously in WSRC-TR-2000-00398. Rheological characterization of the sludge, SRAT product, and SME product material was requested as part of the simulant program.

Samples of sludge simulant, SRAT product, and SME product were taken and analyzed for rheology, particle size, solids content, and $\mathrm{pH}$. Rheological measurements were made of five different sludge simulant preparations and ten different SRAT products at $25^{\circ} \mathrm{C}$. Rheological measurements were made of both Tank 40 SME product and Tank 8/Tank 40 blend SME product over a wide range of wt. $\%$ total solids and at both $25^{\circ} \mathrm{C}$ and $50^{\circ} \mathrm{C}$. The summary table gives key results for the nominal Tank 8/Tank 40 blend sludge and SRAT product. The results for the two SME product samples that bracket the upper DWPF design basis yield stress of 150 dynes $/ \mathrm{cm}^{2}$ are both given.

Nominal Tank 8/40 Blend Results Summary at $25^{\circ} \mathrm{C}$

\begin{tabular}{ccccccc}
\hline Sample & $\begin{array}{c}\text { Total } \\
\text { Solids, } \\
\text { Wt. \% }\end{array}$ & $\begin{array}{c}\text { Insoluble } \\
\text { Solids, } \\
\text { Wt. \% }\end{array}$ & $\begin{array}{c}\text { Yield } \\
\text { Stress, } \\
\text { dynes/cm }\end{array}$ & $\begin{array}{c}\text { Plastic } \\
\text { Viscosity, } \\
\text { cP }\end{array}$ & $\begin{array}{c}\text { Supernate } \\
\mathrm{pH}\end{array}$ & $\begin{array}{c}\text { Volume } \\
\text { Mean Particle } \\
\text { Size, microns }\end{array}$ \\
\hline Sludge & 15.9 & 13.2 & 36 & 8.5 & 10.3 & 4.8 \\
SRAT Product & 16.4 & 11.2 & 35 & 9.4 & 6.8 & 5.6 \\
SME Product & 44.2 & 39.1 & 130 & 17 & 6.8 & 150 \\
SME Product & 48.9 & 42.8 & 260 & 34 & 7.0 & 150 \\
\hline
\end{tabular}

\section{Significant Findings}

- Tank 40 sludge was an order of magnitude more viscous than Tank 8 sludge at comparable wt. \% total solids.

- The 48:52 blend (by total solids content) of Tank 8 and Tank 40 sludge simulants was less viscous than the weighted arithmetic average of the individual sludge viscosities.

- The Olney and Carlson model was reasonably successful in synthesizing a predicted Tank $8 / 40$ blend rheogram from the individual Tank 8 and Tank 40 rheograms. This offers a potential method for predicting the rheology of slurry blends from data on starting slurries. 
WSRC-TR-2001-00051

Page 2 of 53

- The order-of-magnitude yield stress difference between Tank 40 sludge and Tank $8 / 40$ blend sludge did not persist into the respective SRAT or SME products.

- Higher concentrations of noble metals correlated with more viscous SRAT products for both Tank 40 and Tank 8/40 blend sludges.

- Variations in the acid stoichiometry did not produce a significant difference in SRAT product rheology for Tank 8/40 blend simulant. (No similar data available for Tank 40.)

- The rheological characteristics of the Tank 8/40 blend SME product and the Tank 40 SME product were fairly similar (as a function of wt. \% insoluble solids).

- The effect of temperature on the SME product rheological characteristics was relatively minor.

- Tank 40 SME product exceeded the DWPF yield stress design basis of 150 dynes $/ \mathrm{cm}^{2}$ at 48 49 wt. \% total solids. Tank 8/40 blend SME product exceeded this basis at $44-45 \mathrm{wt}$. \% total solids.

- Model fits of the dependence of Bingham fluid model parameters on wt. \% insoluble solids for these two SME products gave results comparable to those obtained in earlier work on other simulated SME products. 
WSRC-TR-2001-00051

Page 3 of 53

\section{BACKGROUND}

The Defense Waste Processing Facility, DWPF, began processing radioactive Tank 51 sludge (Sludge Batch 1A) in 1996 and continued processing with Tank 42 sludge blended with the heel of Tank 51 (Sludge Batch 1B) in 1998. Current plans call for DWPF to begin processing radioactive sludge fed from Tank 40 in mid to late 2001 (Sludge Batch 2). Sludge Batch 2 (Macrobatch 3) includes the radioactive sludge transferred to Tank 40 from Tank 8 in addition to the sludge that was already in Tank 40.

DWPF continues to operate under the sludge-only process flowsheet. Simulant testing was required to demonstrate a sludge-only process for Sludge Batch 2 . This document details the rheological testing performed in support of the Sludge Batch 2 sludge-only process using nonradioactive sludge simulants. The work was completed prior to the transfer of Tank 8 into Tank 40 , and covered the two bounding cases of no Tank 8 transfer and total Tank 8 transfer into Tank 40 .

\section{INTRODUCTION}

SRTC/ITS received a Technical Task Request, HLW/DWPF/TTR-00-0014, "Sludge Batch 2 (Macrobatch 3) Flowsheet Studies", from Maria A. Rios-Armstrong in March of 2000. The task was accepted by Sharon L. Marra, SRT-PTD-2000-0008, on March 13. Daniel P. Lambert was designated as the Task Leader. A Task Technical and QA Plan, WSRC-RP-2000-00191, "Sludge Batch 2 (Macrobatch 3) Flowsheet Studies with Simulants", was issued and approved in mid-May of 2000. David C. Koopman was designated as the lead researcher for this task and had the overall responsibility for coordinating the activities of all participants.

Per the approved Task Plan, several process simulations were performed at different processing conditions to better define satisfactory processing parameters for the new sludge batch. The results of this portion of the program were previously documented in WSRC-TR-2000-00398, Revision 0, Sludge Batch 2 (Macrobatch 3) Flowsheet Studies with Simulants (U), by D. C. Koopman (hereafter known as reference 1). This report completes the requested tasks by documenting measurements of the rheological properties of various simulated sludges, SRAT products, and SME products (melter feeds). These two reports share terminology, etc.

The process simulations duplicated the expected DWPF SRAT and SME processing conditions in laboratory scale vessels. Samples taken during the flowsheet studies (10 SRAT simulations and 4 SME simulations) were used to obtain rheological characterizations of the simulant slurries over a wide range of process conditions.

\section{DISCUSSION}

\section{Experimental Equipment and Methods}

The preparation of simulated Tank 8 and Tank 40 sludges is described elsewhere ${ }^{1}$, as is the generation of the simulated SRAT and SME products ${ }^{1}$. Processing followed the current DWPF nitric acid flowsheet. The acid requirement was calculated using standard algorithms such as those developed by $\mathrm{Hsu}^{2}$. 
WSRC-TR-2001-00051

Page 4 of 53

Samples were subjected to various analyses in support of the rheology work and in support of the flowsheet simulations ${ }^{1}$. These included the wt. \% total solids, wt. \% insoluble solids, particle size distribution, and supernate $\mathrm{pH}$ in addition to compositional data reported earlier ${ }^{1}$.

After analysis, the samples were characterized in a Haake Rotovisco model RV20 concentric cylinder rheometer employing the Searle technique (rotating inner cylinder). The concentric cylinder assembly was placed into a heating jacket in which the temperature was controlled using a cooling/heating bath. Programmed variations in the shear rate produced measurable changes in torque which were converted into shear stress by the Haake software. Instrument performance was checked by running a $102.5 \mathrm{cP}$ silicon oil standard. Results for the standard were always within $\pm 5 \%$. All of the flow curves given in this report are uncorrected, i.e. not corrected for geometry, non-Newtonian behavior, slip, etc.

The sludge and SRAT product samples were measured with the MV1 stainless steel cylindrical rotor $(40.08 \mathrm{~mm}$ outside diameter, $60 \mathrm{~mm}$ length). The SME product samples were measured with the MV2 stainless steel cylindrical rotor (36.8 mm outside diameter, $60 \mathrm{~mm}$ length). MV1 gives a more accurate uncorrected flow curve than MV2, but has too narrow a gap for slurries containing DWPF-sized frit. Both the MV1 and MV2 rotors have recessed bottoms to minimize end effects. The selected rotor was attached to the M5 measuring head drive motor.

Samples were placed in a cylindrical stainless steel cup ( $42 \mathrm{~mm}$ inside diameter). The cup was then mounted into the heating jacket, so as to surround the inner cylindrical rotor. A test was started after allowing two minutes to equilibrate the sample temperature and zero the instrument. Measurements at $50^{\circ} \mathrm{C}$ had the sample and rotor pre-heated to $50^{\circ} \mathrm{C}$ in a separate temperature controlled bath and the cup pre-heated in the water jacket at $50^{\circ} \mathrm{C}$. The rotor, sample, and cup were then assembled as described above.

The rheometer interfaced with a personal computer which stored various rheometer job programs and recorded the output data. The original job program, used for sludge and SRAT product samples, had a cycle time of twelve minutes. It linearly raised the shear rate from 0 to $400 \mathrm{sec}^{-1}$ over a five minute period, maintained $400 \mathrm{sec}^{-1}$ for two minutes, and then linearly decreased the shear rate from 400 to $0 \mathrm{sec}^{-1}$ over five minutes. The shear rate range used for SME product samples was later reduced to 0 to $350 \mathrm{sec}^{-1}$ (the program linearly raised the shear rate from 0 to $350 \mathrm{sec}^{-1}$ in five minutes, maintained $350 \mathrm{sec}^{-1}$ for two minutes, and then linearly decreased the shear rate from 350 to $0 \mathrm{sec}^{-1}$ over five minutes). Due to difficulties with slurry drying at $50^{\circ} \mathrm{C}$, the overall cycle time was further reduced from 12 minutes to 9.75 minutes. The elevated temperature job program reduced the two ramp times from five minutes to 4.375 minutes (350/400 of five minutes), and reduced the hold at $350 \mathrm{sec}^{-1}$ from two minutes to one minute.

Six samples of Tank 8/Tank 40 Blend-based SME product were prepared spanning a $15 \%$ range in wt. \% insoluble solids. The samples were all prepared from the nominal case run of the Tank $8 / 40$ simulant during the Macrobatch 3 flowsheet study (SB2-1) ${ }^{1}$. The SME product, as made during the process simulation, was initially about $44 \mathrm{wt} . \%$ total solids. Condensate was collected at the end of the SME cycle for dilution purposes. It was necessary to increase the wt. $\%$ total solids of a portion of the $44 \mathrm{wt}$ \% total solids SME product up to about $55 \mathrm{wt}$. \% total solids to get the necessary range. The remaining samples were prepared by diluting either the 55 
WSRC-TR-2001-00051

Page 5 of 53

or the $44 \mathrm{wt}$ \% total solids product with the SME condensate to produce a sample set with approximately $3 \%$ increments in wt. \% insoluble solids (nominally: 33.5, 36.5 39.5, 42.5, 45.5, and 48.5 wt. \%).

A matching set of six samples was prepared using the Tank 40 SME product produced during the Macrobatch 3 flowsheet study (SB2-2) ${ }^{1}$. The initial SME product was about 49 wt. $\%$ total solids, and a portion was concentrated to about $57 \mathrm{wt}$ \% total solids. Dilutions were then made with condensate collected during the corresponding SME cycle. The resulting six samples were also nominally $33.5,36.539 .5,42.5,45.5$, and $48.5 \mathrm{wt}$. \% insoluble solids.

Additional samples for rheology purposes were pulled at the end of each SRAT cycle during the four variability study runs ${ }^{1}$. There were also six SRAT products available for rheology measurements from the two Tank 40 scoping runs (1A, 2A) and the four Tank 8/40 blend scoping runs (1B-4B) ${ }^{1}$. The scoping runs were terminated at the end of the SRAT cycle. Approximately 2000 grams of SRAT product material was available from each scoping run.

Samples of washed sludge simulant were also collected for rheological investigation. These included Tank 8 sludge, Tank 40 sludge, Tank 40 sludge trimmed with manganese (IV) oxide and nickel (II) chloride, Tank $8 / 40$ blend sludge (a blend of Tank 8 sludge simulant with the Tank 40 sludge trimmed with $\mathrm{Mn}$ and $\mathrm{Ni}$ ), and some older Tank 42 sludge. The Tank 42 sludge was Optima Tank 51 sludge simulant trimmed to approximate Sludge Batch 1B (Macrobatch 2) composition.

The total weight percent solids content of slurry and filtered supernate samples were determined. Known masses were dried overnight in an oven. The oven temperature was $110-115^{\circ} \mathrm{C}$. Slurry samples were dried to determine the wt. \% total solids. A portion of the slurry was also filtered ( 0.45 micron filter) to obtain a supernate sample. The $\mathrm{pH}$ of the supernate was measured, and then a portion was oven dried to determine the total solids (dissolved solids) content of the supernate. Duplicate samples of both the slurry and supernate were dried to verify the reproducibility of results obtained. Results of duplicate samples were averaged. Wt. \% insoluble solids concentration in the sludge/slurry were calculated using equation [1] from the two measurement averages by:

$$
w t . \%_{i s}=\frac{w t . \%_{t s}-w t . \%_{d s}}{100 \%-w t . \%_{d s}} \cdot 100 \%
$$

Where: $\quad w t . \%_{t s}=$ weight percent total solids concentration in the slurry

$w t . \%_{d s}=$ weight percent dissolved solids concentration in the supernate

$w t . \%_{\text {is }}=$ weight percent insoluble solids concentration in the slurry

Measurements of $\mathrm{pH}$ were made with either a Fisher Scientific accumet ${ }^{\circledR}$ model $15 \mathrm{pH}$ meter or a UniFET Model UF100-1 pH meter. The instruments were calibrated using $\mathrm{pH} 4$ and $\mathrm{pH} 10$ buffer solutions, and then checked against a $\mathrm{pH} 7$ buffer. Indicated instrument results were within $0.1 \mathrm{pH}$ unit for the $\mathrm{pH} 7$ buffer. Particle size measurements were made by the Analytical Development Section using a MicroTrac-SRA150 analyzer, running version 7.01. Samples were 
WSRC-TR-2001-00051

Page 6 of 53

run in triplicate and averaged before reporting. The eleven average particle size distribution scans from this study can be found in Appendix I.

\section{SME Product Results}

Simulant SME product rheology has been investigated in numerous earlier studies ${ }^{4,5}$. The DWPF design bases include limits of 25-150 dynes $/ \mathrm{cm}^{2}$ for yield stress and 10-40 centipoise (cP) for the plastic viscosity of the melter feed (SME product). The flow curves obtained in this task were modeled using the Bingham plastic fluid rheological model, equation [2].

$$
\tau=\tau_{o}+\eta \dot{\gamma}
$$

Where: $\quad \tau=$ shear stress $\left(\right.$ dynes $\left./ \mathrm{cm}^{2}\right)$

$\dot{\gamma}=$ shear rate, $(1 /$ seconds $)$

$\tau_{o}=$ Bingham model yield stress $\left(\right.$ dynes $\left./ \mathrm{cm}^{2}\right)$

$\eta=$ Bingham model consistency, or Bingham plastic viscosity, (cP)

Uncorrected flow curve data was fit to equation [2].

Tank 8/Tank 40 SME Product Results

Table 1 summarizes the analytical data and Bingham fluid model parameters determined at $25^{\circ}$ and $50^{\circ} \mathrm{C}$ for the nominal Tank 8/Tank 40 blend-based SME product slurries (Sludge Batch 2, flowsheet study run 1, abbreviated SB2-1). Both the yield stress and plastic viscosity increased as the solids loading increased. 
WSRC-TR-2001-00051

Page 7 of 53

Table 1. Summary of Tank 8/40 Blend SME Product Results

\begin{tabular}{|c|c|c|c|c|c|}
\hline $\begin{array}{c}\text { Total Solids, } \\
\text { Wt. \% }\end{array}$ & $\begin{array}{c}\text { Insoluble } \\
\text { Solids, Wt. \% }\end{array}$ & $\begin{array}{c}\text { Temperature, } \\
{ }^{\circ} \mathrm{C}\end{array}$ & $\begin{array}{c}\text { Yield Stress, } \\
\text { dynes } / \mathrm{cm}^{2}\end{array}$ & $\begin{array}{c}\text { Plastic } \\
\text { Viscosity, cP }\end{array}$ & Supernate $\mathrm{pH}$ \\
\hline \multirow[t]{2}{*}{37.8} & 33.7 & 25 & 40 & 13 & 6.9 \\
\hline & & 50 & 40 & 10 & \\
\hline \multirow[t]{2}{*}{41.0} & 36.4 & 25 & 70 & 18 & 6.8 \\
\hline & & 50 & 80 & 16 & \\
\hline \multirow[t]{2}{*}{44.2} & 39.1 & 25 & 130 & 17 & 6.8 \\
\hline & & 50 & 120 & 18 & \\
\hline \multirow[t]{2}{*}{48.9} & 42.8 & 25 & 260 & 34 & 7.0 \\
\hline & & 50 & 330 & 27 & \\
\hline \multirow[t]{2}{*}{51.7} & 45.3 & 25 & 400 & 41 & 6.9 \\
\hline & & 50 & 500 & 17 & \\
\hline \multirow[t]{2}{*}{55.0} & 48.2 & 25 & 680 & 67 & 7.0 \\
\hline & & 50 & 970 & 87 & \\
\hline
\end{tabular}

The Bingham fluid model parameters were generally fit over the shear rate range of 25-300 $\sec ^{-1}$ using the data from the ramp-up period. If there was considerable curvature at low shear rates, then the range was shortened on the lower end. If there was a suggestion of settling or binding at higher shear rates, then the range was shortened on the upper end. Bingham fluid model fits were particularly difficult for the $50^{\circ} \mathrm{C}$ data for the Tank 8/40 blend SME product. Rheograms obtained were of lower than desired quality in almost all cases (high curvature, thickening during the hold period, etc.). Selected samples were rerun and produced comparable results (in terms of rheogram quality, not reproducibility). More than a single factor was hypothesized to be influencing the measurements. These included evaporation loss, aggregation or segregation of solids, and/or the presence of small air bubbles.

The hold period at the maximum imposed shear rate generally exhibited an increasing shear stress with time. The data from the down ramp in shear rate generally were highly nonlinear and not reproducible. This was taken as evidence that the slurries were not stable in the rheometer on time scales of six to twelve minutes. One place this seemed most evident was in the plastic viscosity data for the samples from 48.9-55 wt. \% total solids. No clear trend in the effect of temperature on plastic viscosity could be discerned.

This "time in instrument" phenomena was examined with SME product available from the variability study with HM levels of noble metals (SB2-3). The SB2-3 melter feed was 44.1 wt. $\%$ total solids. Two different ramp rates were tested. It appeared that faster ramp-up and rampdown times for the shear rate produced up and down curves that were closer together (Run 4 using two minute ramp-up and ramp-down durations). Slower ramp-up and ramp-down times 
WSRC-TR-2001-00051

Page 8 of 53

(Runs 2 and 3 using five minute ramp-up and ramp-down durations) gave poorer matches and were not reproducible. Associated with the change in ramp time was a shift in the calculated plastic viscosity, but almost no significant shift in the calculated yield stress.

Figure 1 shows graphically what occurred. Data are labeled by run number in Figure 1 . The yield stress was about 10 pascals, or 100 dynes $/ \mathrm{cm}^{2}$, based on any of the six up and down curves, i.e. yield stress was fairly insensitive to the shear rate control method. Up-curve plastic viscosities ranged from 21 to $53 \mathrm{cP}$, i.e. even five minutes was long enough to produce variations in the plastic viscosity.

The measurements being discussed are dynamic. Any relaxation period for the shear stress as a function of shear rate, and the shear rate ramp rate, remains indeterminate. A new instrument is being commissioned which will permit the measurement of time-independent rheological properties, i.e. properties at rheological steady-state. The shear stress hardly changed during the Run 2 hold for two minutes, but the shear stress changed greatly during the comparable time for Run 3. This could be related to drying of the sample at the exposed upper limit of the concentric cylinders as well as to slurry settling.

Figure 1. Tank 8/Tank 40 SME Product Containing HM Levels of Noble Metals at $25^{\circ} \mathrm{C}$

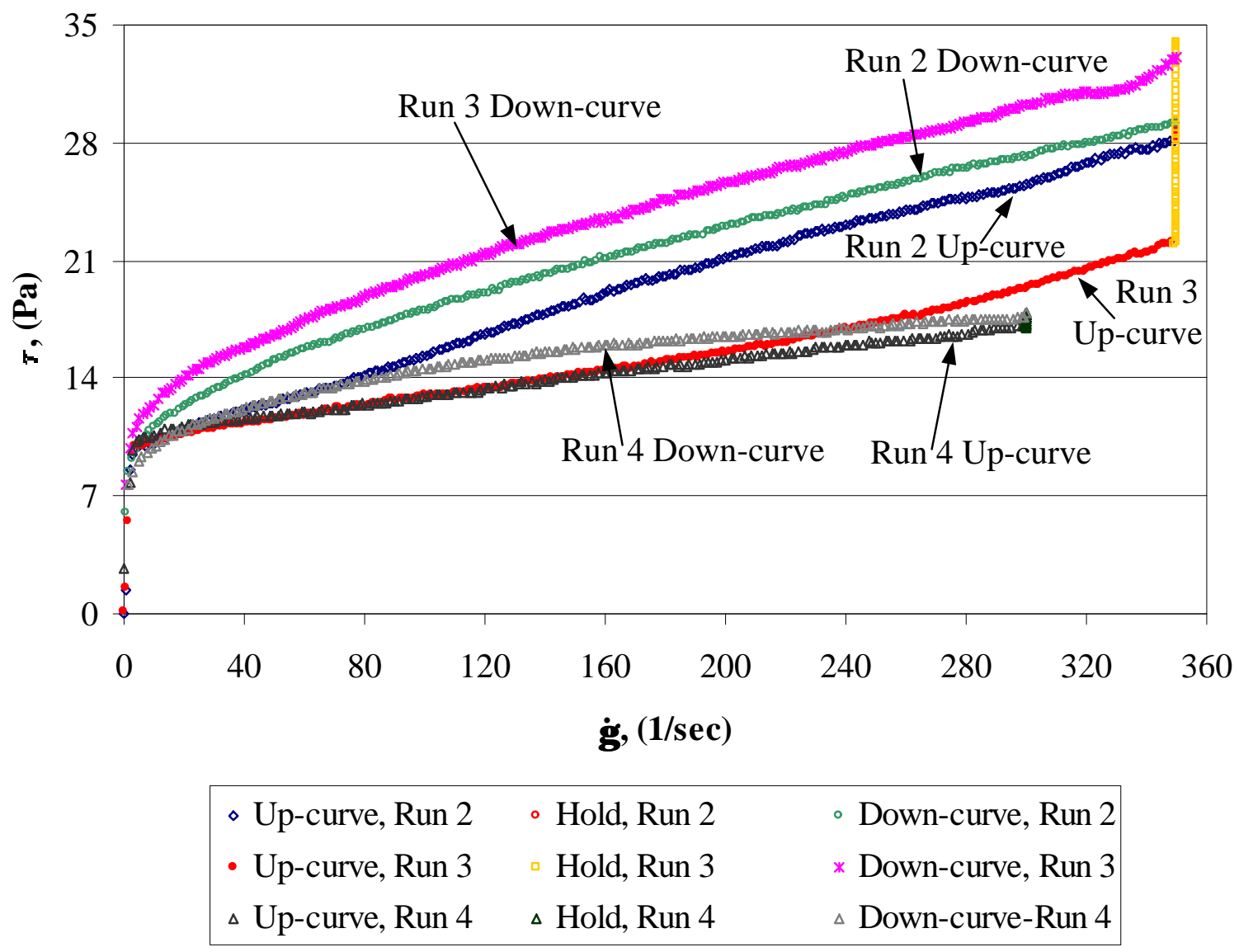


WSRC-TR-2001-00051

Page 9 of 53

Figure 2 shows the best raw rheogram data for the six nominal run (SB2-1) Tank 8/40 samples at $25^{\circ} \mathrm{C}$ during just the shear rate ramp-up period. Most rheogram figures that follow will focus on the shear rate ramp-up portion of the data, since the slurries have had the least amount of time to segregate during this portion of the measurement cycle. The dashed line in Figure 2 indicates 150 dynes $/ \mathrm{cm}^{2}$, the DWPF yield stress upper design basis and will be shown in the majority of subsequent flow curves as a reference point. Rheograms are labeled by the wt. $\%$ total solids of the sample.

Figure 2. Nominal Tank 8/Tank 40 SME Product Flow Curves at $25^{\circ} \mathrm{C}$

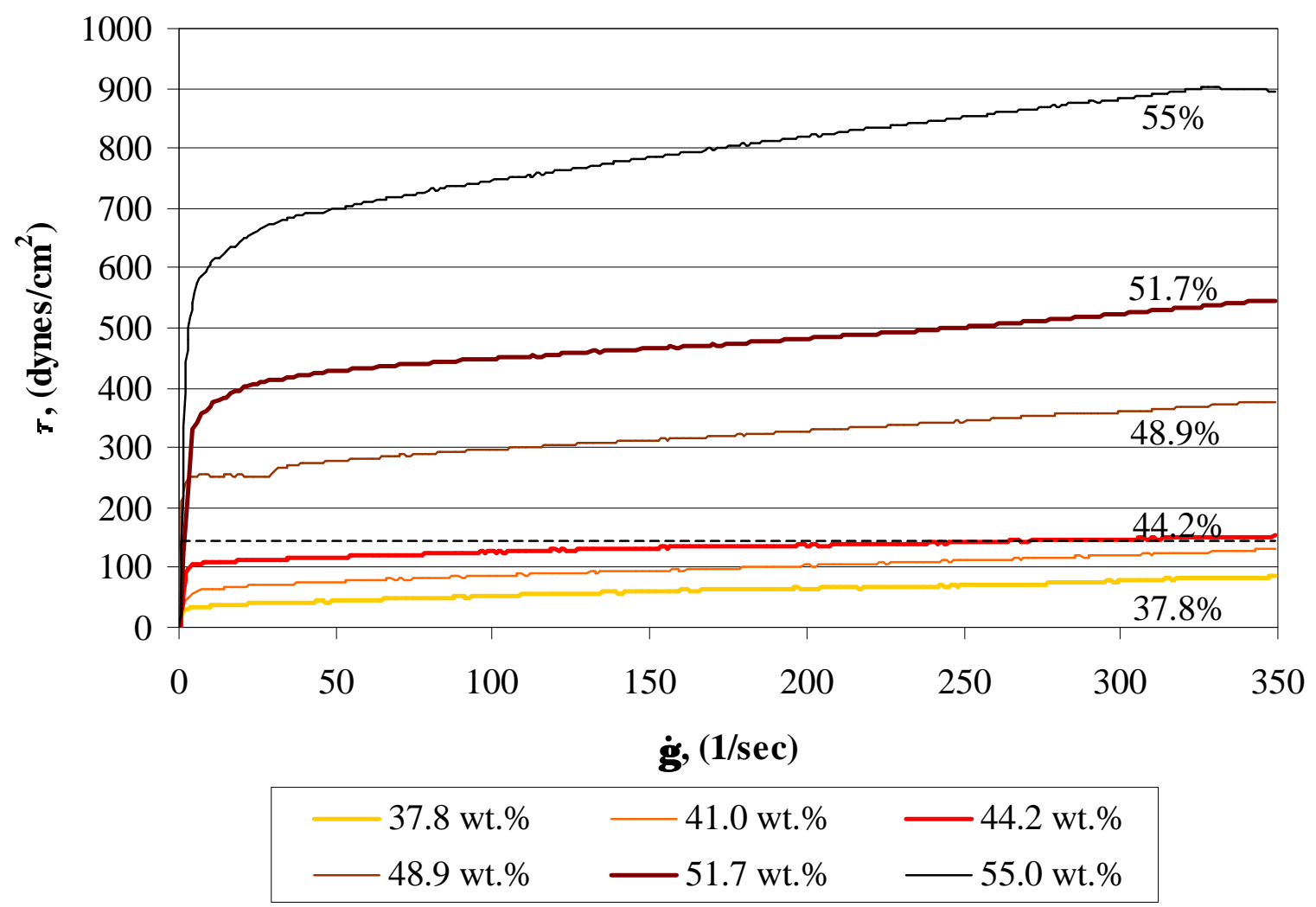

Figure 3 shows equivalent results for $50^{\circ} \mathrm{C}$. 
WSRC-TR-2001-00051

Page 10 of 53

Figure 3. Nominal Tank 8/Tank 40 SME Product Flow Curves at 50 ${ }^{\circ} \mathrm{C}$

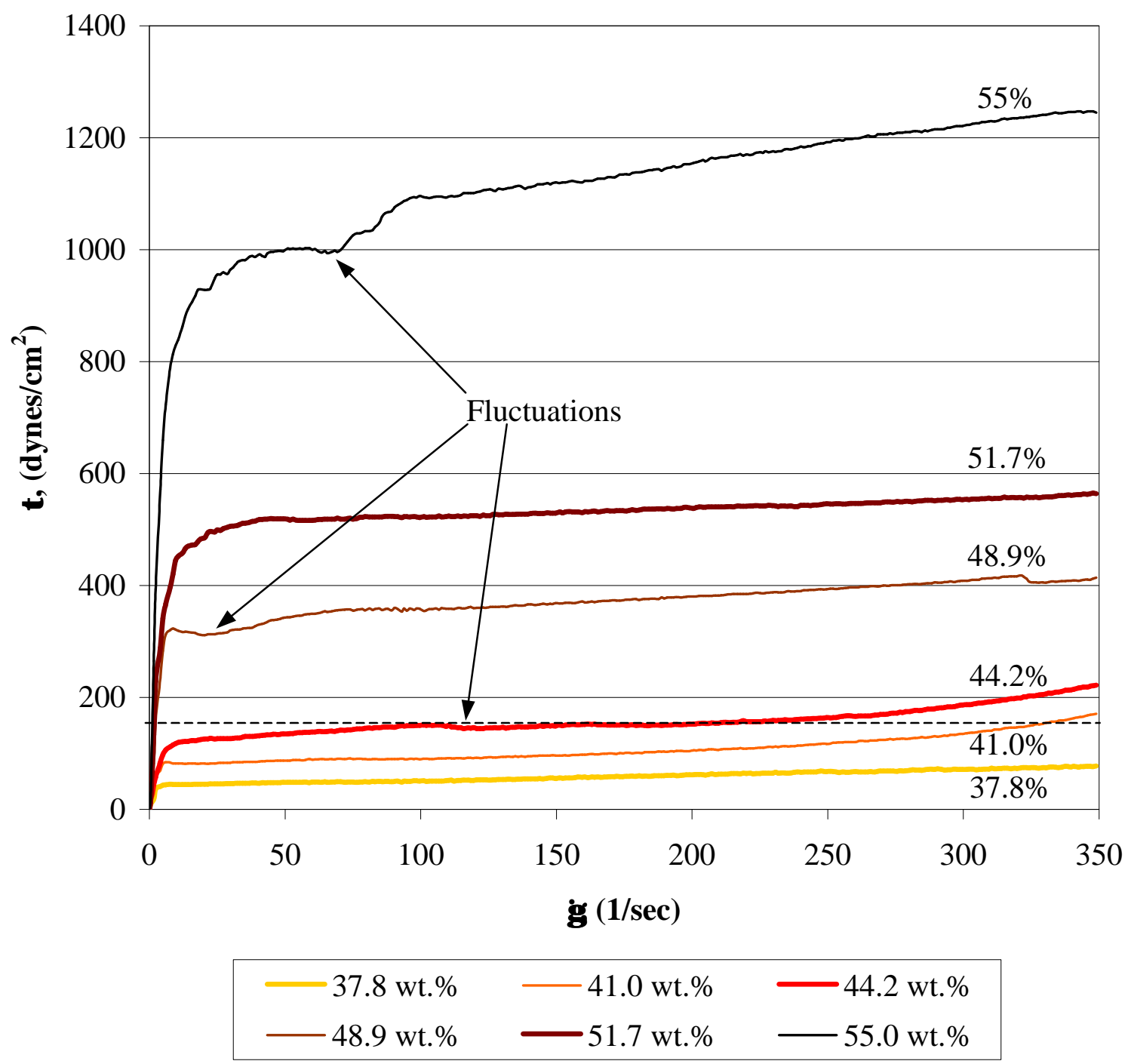

Note the slight upward curvature between 250 and $350 \mathrm{sec}^{-1}$ for the 41 and $44 \mathrm{wt} . \%$ total solids samples, as well as the fluctuating data between 10 and $100 \mathrm{sec}^{-1}$ for the 44,49 , and $55 \mathrm{wt} \%$ total solids samples in Figure 3. Figure 4 gives a head-to-head comparison of the two temperatures studied for four of the sample pairs above. The other two show similar behavior, but were excluded for clarity. 
WSRC-TR-2001-00051

Page 11 of 53

Figure 4. Tank 8/Tank 40 SME Product Flow Curves at 25 and $50^{\circ} \mathrm{C}$

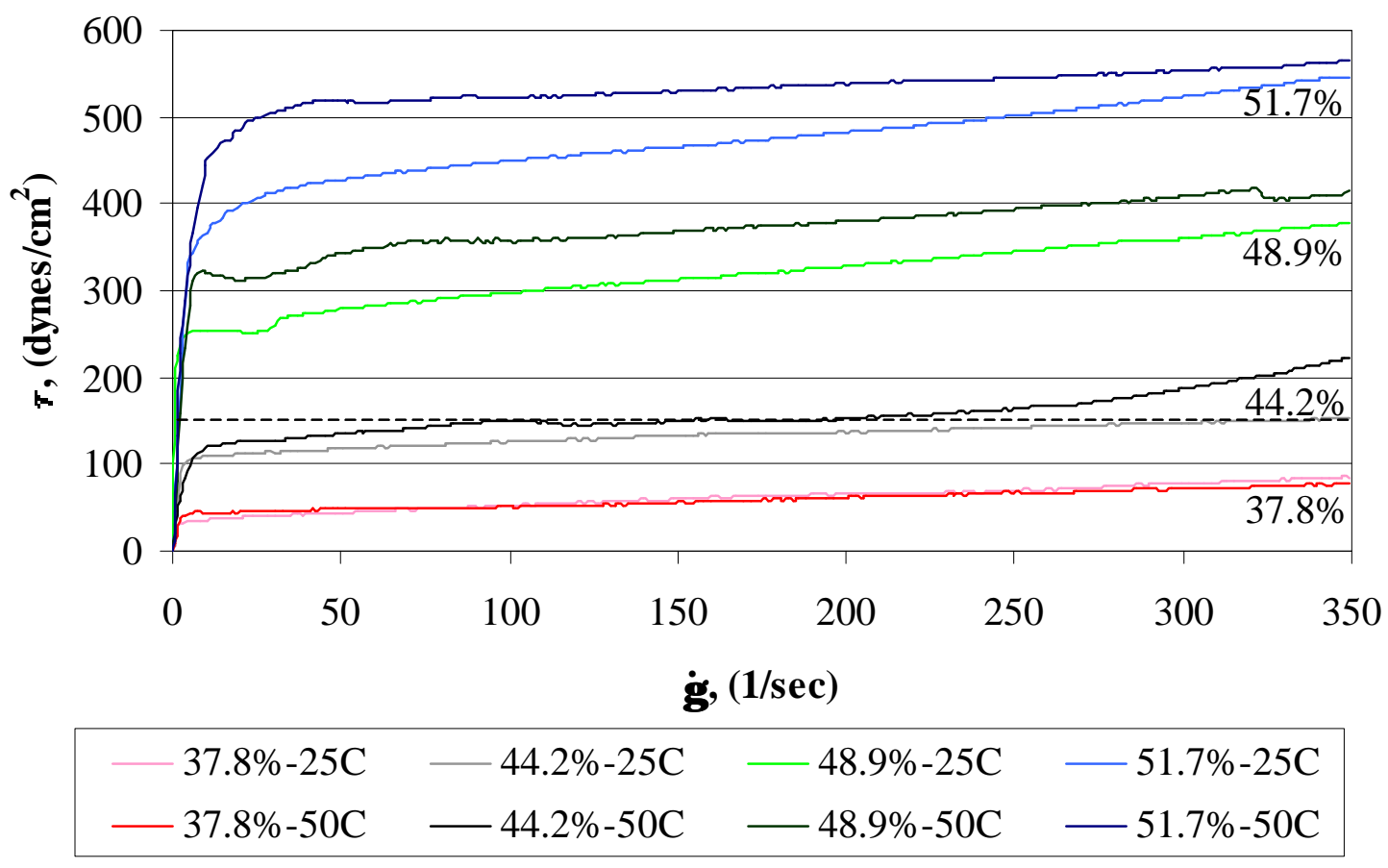

The samples at low wt. \% total solids were almost insensitive to temperature, while those at higher wt. \% showed a more viscous flow curve with increasing temperature as shown in Figure 4. This could be due to sample water loss during analysis. Similar phenomena were observed with samples from the DWPF-0005 study by Marek ${ }^{4}$.

\section{Tank 40 SME Product Results}

Table 2 summarizes the analytical data and Bingham fluid model parameters determined at $25^{\circ} \mathrm{C}$ and $50^{\circ} \mathrm{C}$ for the Tank 40 -based SME product slurries. The table indicates that both the yield stress and plastic viscosity increased as the solids loading was increased. 
WSRC-TR-2001-00051

Page 12 of 53

Table 2. Summary of Tank 40 SME Product Results

\begin{tabular}{|c|c|c|c|c|c|}
\hline $\begin{array}{l}\text { Total Solids, } \\
\text { Wt. \% }\end{array}$ & $\begin{array}{c}\text { Insoluble } \\
\text { Solids, Wt. \% }\end{array}$ & $\begin{array}{c}\text { Temperature, } \\
{ }^{\circ} \mathrm{C}\end{array}$ & $\begin{array}{l}\text { Yield Stress, } \\
\text { dynes } / \mathrm{cm}^{2}\end{array}$ & $\begin{array}{c}\text { Plastic } \\
\text { Viscosity, cP }\end{array}$ & Supernate $\mathrm{pH}$ \\
\hline 38.9 & 33.7 & $\begin{array}{l}25 \\
50\end{array}$ & $\begin{array}{l}30 \\
40\end{array}$ & $\begin{array}{l}14 \\
12\end{array}$ & 4.0 \\
\hline 41.0 & 35.8 & $\begin{array}{l}25 \\
50\end{array}$ & $\begin{array}{l}65 \\
60\end{array}$ & $\begin{array}{l}21 \\
22\end{array}$ & 4.0 \\
\hline 44.8 & 38.9 & $\begin{array}{l}25 \\
50\end{array}$ & $\begin{array}{l}110 \\
110\end{array}$ & $\begin{array}{l}33 \\
27\end{array}$ & 4.0 \\
\hline 49.3 & 43.2 & $\begin{array}{l}25 \\
50\end{array}$ & $\begin{array}{l}170 \\
170\end{array}$ & $\begin{array}{l}54 \\
39\end{array}$ & 3.9 \\
\hline 53.7 & 46.0 & $\begin{array}{l}25 \\
50\end{array}$ & $\begin{array}{l}310 \\
330\end{array}$ & $\begin{array}{l}61 \\
72\end{array}$ & 4.1 \\
\hline 57.1 & 49.5 & $25^{\dagger}$ & 600 & 100 & 4.1 \\
\hline
\end{tabular}

$\dagger-$ There was insufficient $57.1 \mathrm{wt}$. $\%$ material left following the $25^{\circ} \mathrm{C}$ analysis to perform a $50^{\circ} \mathrm{C}$ analysis.

Figure 5 shows the raw flow curve data for the six Tank 40 samples at $25^{\circ} \mathrm{C}$ during the shear rate ramp-up period. Data are labeled by wt. $\%$ total solids in the sample. The Tank 40 SME product $\mathrm{pH}$ was considerably lower than the Tank $8 / 40$ blend SME product $\mathrm{pH}$. This was attributed to a combination of two processing factors, higher acid stoichiometry coupled with lower noble metal concentrations. The Tank 40 run was at $137.5 \%$ acid stoichiometry, while the Tank 8/40 blend run was at $125 \%$. The Tank 40 run noble metals were several orders of magnitude lower than the Tank 8/40 blend. This correlated with less hydrogen and carbon dioxide generation, presumably tracking a lower net destruction of formic acid. Additional processing details can be found in the flowsheet studies report ${ }^{1}$. 
WSRC-TR-2001-00051

Page 13 of 53

Figure 5. Tank 40 SME Product Flow Curves at $25^{\circ} \mathrm{C}$

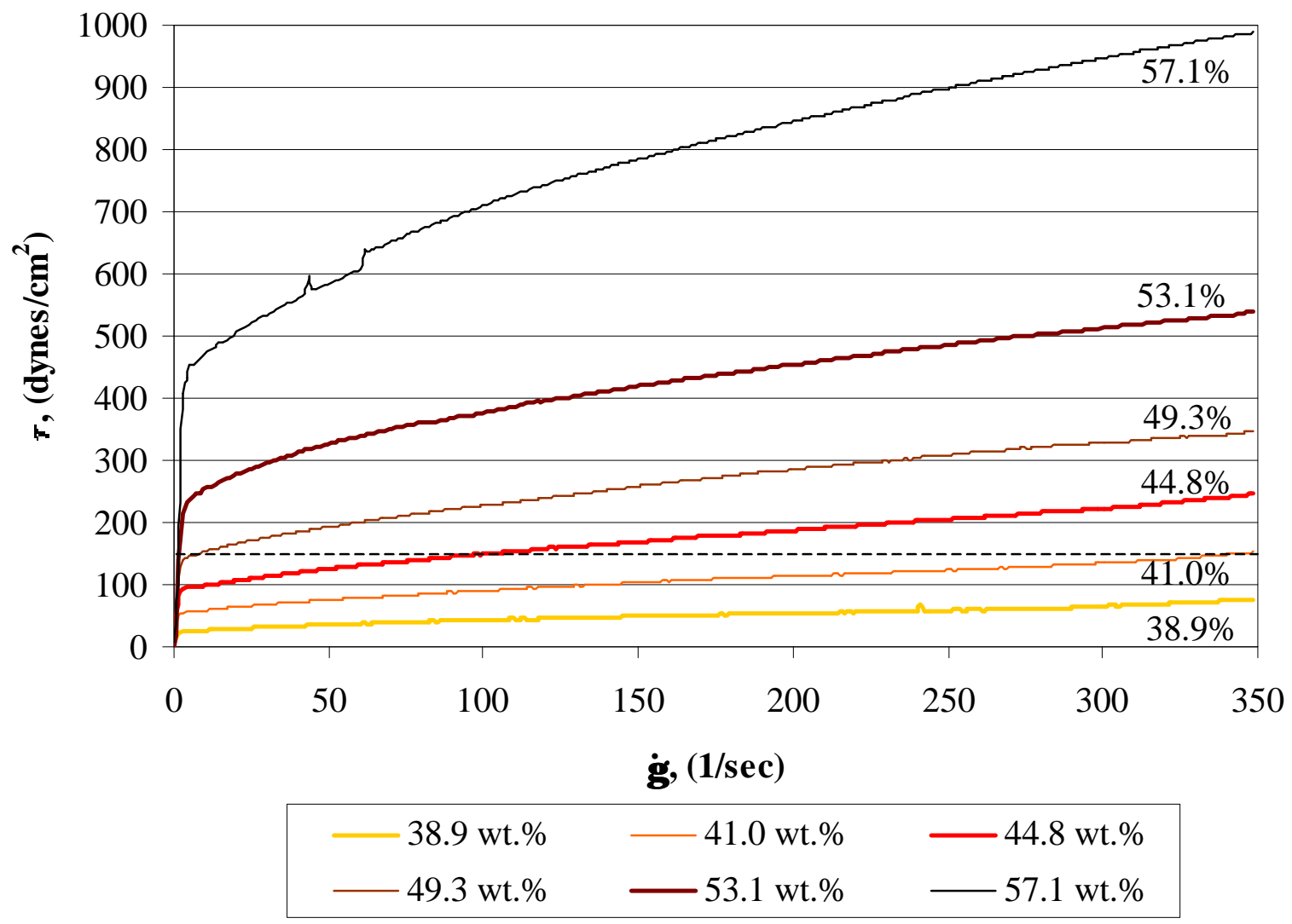

The 57.1 wt. \% total solids material was very thick and difficult to handle. The shear rate rampup data generally showed a slight bowing suggesting additional pseudoplastic behavior on the interval 10-300 $\mathrm{sec}^{-1}$. Conversely, there was frequently an increase in shear stress (and never a decrease) during the hold at the maximum shear rate. This was more suggestive of rheopectic behavior. These seemingly contradictory statements could be related to the potential centrifugation of frit off the inner moving rotor coupled with settling to produce a high shear region in the bottom of the concentric cylinder, to the presence of small bubbles in the starting sample, or to other unidentified effects.

Figure 6 below gives the Tank 40 SME product ramp-up shear rate-shear stress data at $50^{\circ} \mathrm{C}$. 
WSRC-TR-2001-00051

Page 14 of 53

Figure 6. Tank $40 \mathrm{SME}$ Product Flow Curves at $50^{\circ} \mathrm{C}$

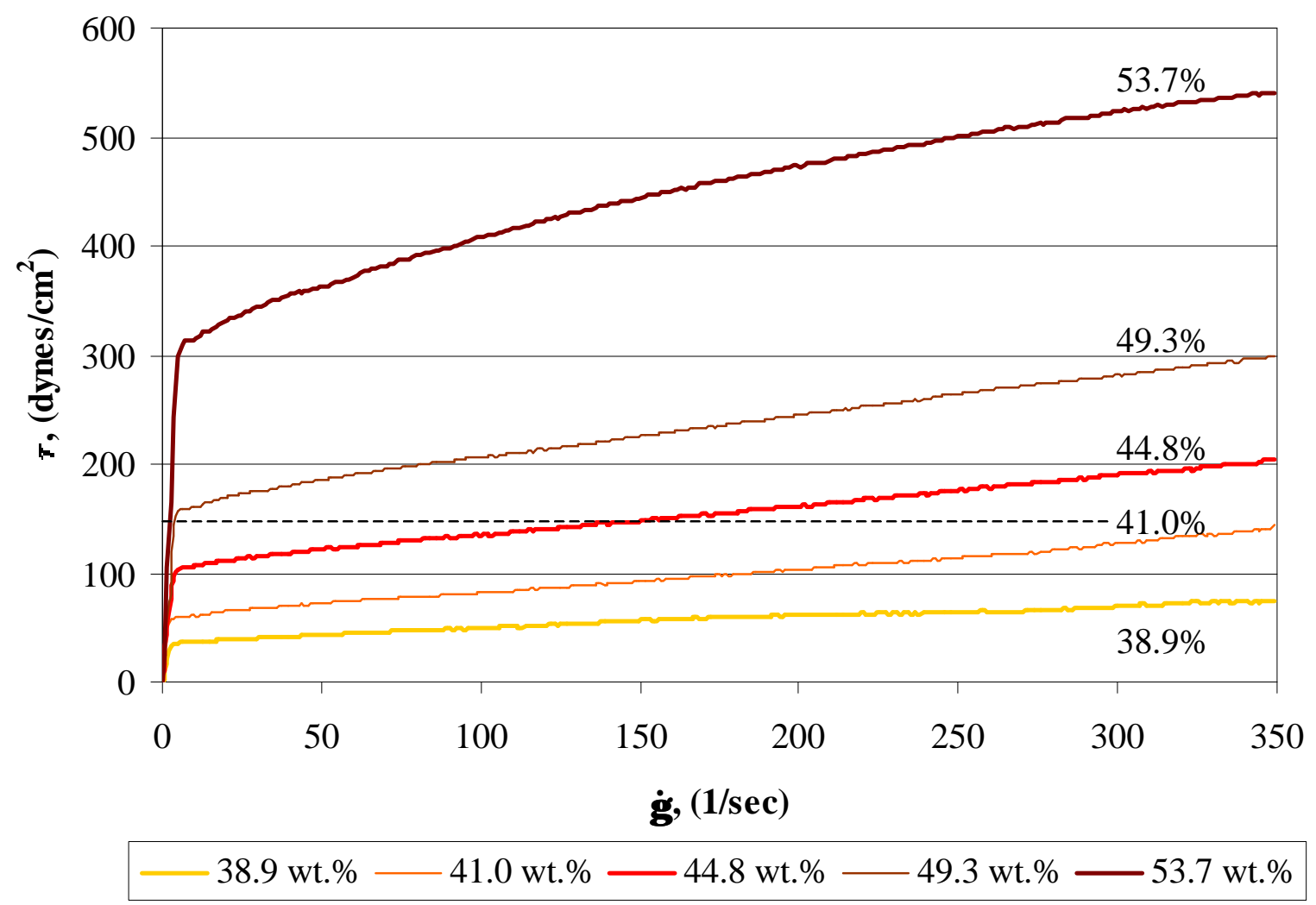

The similarities between the data in Figures 5 and 6 were considerable. This is seen more clearly in Figure 7, which compares four pairs of results at both $25^{\circ} \mathrm{C}$ and $50^{\circ} \mathrm{C}$. The fifth pair is omitted for clarity. The yield stresses are almost independent of temperature, and the plastic viscosities are fairly similar within each pair (perhaps within the reproducibility of the measurements). 
WSRC-TR-2001-00051

Page 15 of 53

Figure 7. Tank 40 SME Product Flow Curves at 25 and $50^{\circ} \mathrm{C}$

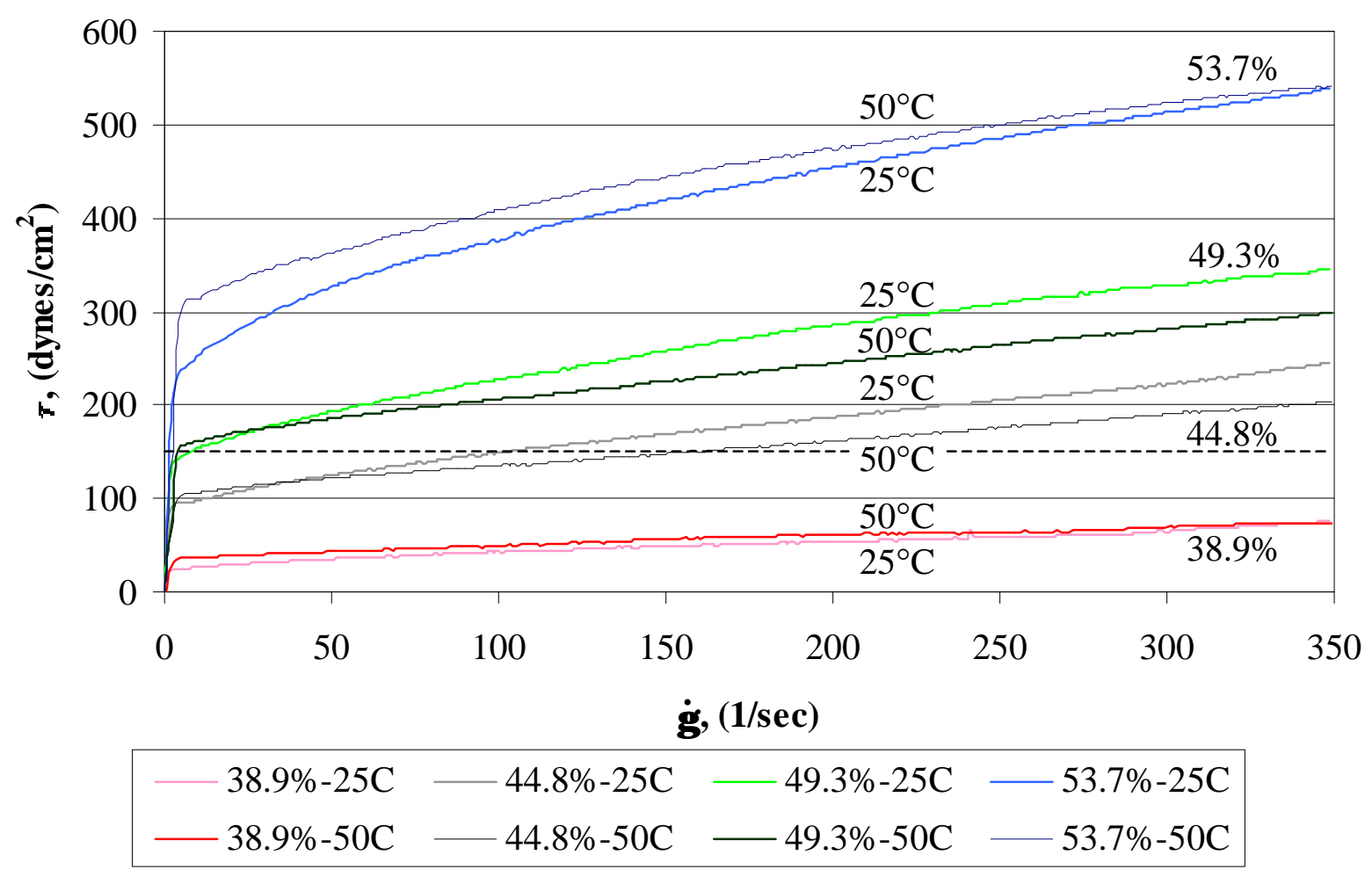

The Tank 40 SME product rheograms generally had smoother ramp-up curves than the blended simulant SME product.

Tank 40 sample ramp-down flow curve data was inconsistent. This was also the case with the blend samples, Figure 1. Variations in the appearance of Tank 40 sample ramp-down data versus ramp-up data are shown in Figure 8. The variations were less pronounced than much of the Tank 8/40 blend data in Figure 1. The presence of these variations can only mean that the plastic viscosities reported here are of lower accuracy than the yield stresses. Yield stress can almost be read off the graph without mathematical curve-fitting, assuming the fluid behaves as a Bingham fluid. Yield stress was also seen to be fairly independent of the shear rate control program used per Figure 1. 
WSRC-TR-2001-00051

Page 16 of 53

Figure 8. Entire Flow Curve Data for Two Tank 40 SME Products at $50^{\circ} \mathrm{C}$

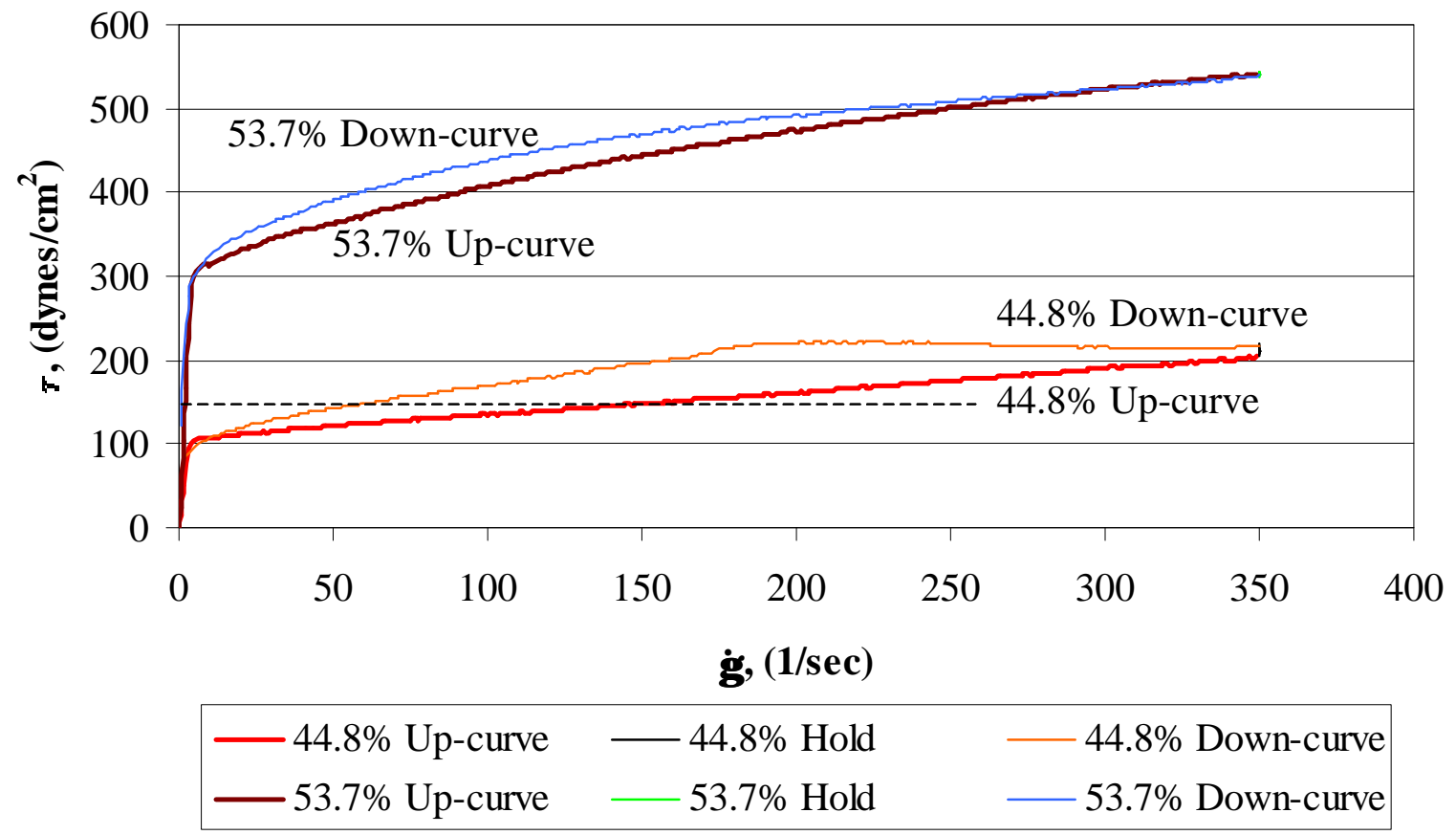

Particle Size Data for SME Products

Particle size distribution results for the four SME products produced in the flowsheet study (SB2-1 to SB2-4) gave very similar results overall (see Appendix I). This was not surprising, since the SME product samples were dominated by frit 200 . There were, however, some subtle differences in the sludge portion of the particle size distributions. These are discussed further at the end of Appendix I, since the implications of the data appear to be more related to SRAT and SME processing issues and to simulant preparation than to rheology. Table 3 summarizes the particle size data. 
WSRC-TR-2001-00051

Page 17 of 53

Table 3. Summary of Particle Size Data for SME Products from Process Simulations

\begin{tabular}{|c|c|c|c|c|c|c|}
\hline & $\begin{array}{c}\text { Mean } \\
\text { diameter, } \\
\text { volume, } \\
\text { microns }\end{array}$ & $\begin{array}{c}\text { Mean } \\
\text { diameter, } \\
\text { area, } \\
\text { microns }\end{array}$ & $\begin{array}{c}\text { Mean } \\
\text { diameter, } \\
\text { number, } \\
\text { microns }\end{array}$ & $\begin{array}{c}\text { Total } \\
\text { Solids, } \\
\text { wt. \% }\end{array}$ & $\begin{array}{c}\text { Yield } \\
\text { Stress at } \\
25^{\circ} \mathrm{C}, \\
\text { dynes/cm }\end{array}$ & $\begin{array}{c}\text { Plastic } \\
\text { Viscosity } \\
\text { at } 25^{\circ} \mathrm{C}, \\
\mathrm{cP}\end{array}$ \\
\hline SB2-1 (Tank 8/40) & 149.8 & 14.54 & 1.127 & 44.2 & 130 & 17 \\
\hline SB2-2 (Tank 40) & 152.5 & 24.62 & 1.222 & 44.8 & 110 & 33 \\
\hline $\begin{array}{l}\text { SB2-3 (Tank } 8 / 40 \text {, with } \\
\text { HM noble metals) }\end{array}$ & 153.1 & 18.08 & 1.195 & 44.1 & 100 & 30 \\
\hline $\begin{array}{l}\text { SB2-4 (Tank 8/40, 2x } \\
\text { noble metals, 290\% acid) }\end{array}$ & 150.3 & 13.06 & 1.080 & 47.3 & - & - \\
\hline
\end{tabular}

The four-run average of the volume mean diameters was $151.4 \mu \mathrm{m}$ with a standard deviation of $1.6 \mu \mathrm{m}(1 \%)$. The four-run average of the number mean diameters was $1.156 \mu \mathrm{m}$ with a standard deviation of $0.064 \mu \mathrm{m}(5.5 \%)$. This data indicate that the four melter feeds were not grossly different in their particle size characteristics in spite of the different starting sludges and processing conditions. (The MicroTrac analyzer assigns a length (equivalent diameter), area, and volume to the particles in each of the finite size ranges in which it counts particles. The various mean diameters above are weighted averages based on the assigned particle volume, area, or length, respectively.)

The SB2-4 SME product was not analyzed on the Haake rheometer, since it was not a likely melter feed (290\% acid stoichiometry). Nevertheless the SB2-4 SME product had similar particle size characteristics to the other SME products. The SB2-3 SME product would not have been analyzed on the rheometer either, but this material was used to study the "time in instrument" phenomena.

A purely phenomenological explanation of slurry rheology with no chemical effects would suggest that slurries with similar particle size distributions will have similar rheological properties. Although the Tank 40 and the Tank 8/40 blend SME products have different rheological properties, the differences are not that great. This will be discussed further in the analysis of wt. \% solids effects later in this report.

\section{SRAT Product Results}

Ten SRAT products were available from the Macrobatch 3 flowsheet study. Three of these were based on Tank 40 sludge with $137.5 \%$ acid stoichiometry and two different levels of noble metals. The remaining seven were based on Tank 8/Tank 40 blend sludge and included various acid stoichiometries and levels of noble metals. SRAT product rheograms shown below were measured using the MV1 head. (One blend sample that seemed to be giving poor results using the MV1 rotor was also analyzed with the NV rotor. The resulting rheogram was better in some 
WSRC-TR-2001-00051

Page 18 of 53

ways and worse in others than those obtained with the MV1 rotor. Data below will only be from the MV1 rotor data set.)

Table 4 summarizes the available Tank 40 SRAT product data including Bingham fluid model fits of the ramp-up shear rate data to the Bingham fluid model. The volume mean particle diameter is included for the single sample submitted in this group.

Table 4. Summary of Tank 40 SRAT Product Results at $25^{\circ} \mathrm{C}$

\begin{tabular}{ccccccc}
\hline Sample & $\begin{array}{c}\text { Total } \\
\text { Solids, } \\
\text { Wt. \% }\end{array}$ & $\begin{array}{c}\text { Insoluble } \\
\text { Solids, } \\
\text { Wt. \% }\end{array}$ & $\begin{array}{c}\text { Yield } \\
\text { Stress, } \\
\text { dynes/cm }\end{array}$ & $\begin{array}{c}\text { Plastic } \\
\text { Viscosity, } \\
\text { cP }\end{array}$ & $\begin{array}{c}\text { Supernate } \\
\text { pH }\end{array}$ & $\begin{array}{c}\text { Volume Mean } \\
\text { Particle Size, } \\
\text { microns }\end{array}$ \\
\hline 1A & 17.9 & not meas. & 100 & 17 & 9.72 & not meas. \\
2A & 18.4 & not meas. & 50 & 10 & 4.50 & not meas. \\
SB2-2 & 18.8 & 11.6 & 50 & 11 & 4.38 & 13.2 \\
\hline
\end{tabular}

The 1A sample $\mathrm{pH}$ of 9.72 was unusually high for a SRAT product. All normal SRAT processing goals, such as nitrite destruction, were met. SRAT $\mathrm{pH}$ fell to 4.1 before rising to 9.7 by the end of the SRAT cycle. Sludge used in 1A had several orders of magnitude higher noble metal concentrations than the other two ${ }^{1}$. This coincided with increased consumption of formic acid during the SRAT cycle, and a correspondingly higher $\mathrm{pH}$. Figure 9 shows the flow curves obtained during the shear rate ramp-up period for the three Tank 40 SRAT product samples. 
WSRC-TR-2001-00051

Page 19 of 53

Figure 9. Tank 40 SRAT Product Flow Curves at $25^{\circ} \mathrm{C}$

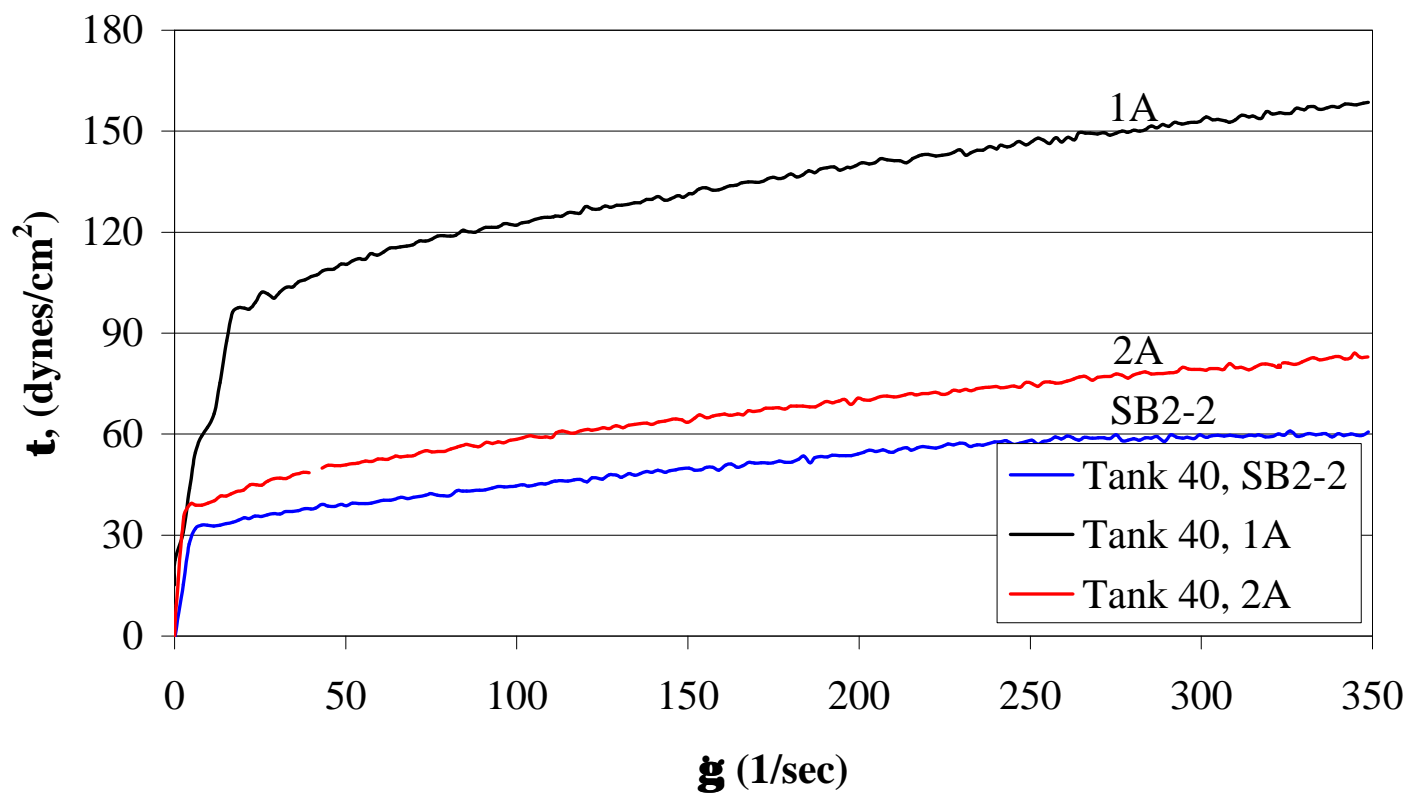

It is not yet possible to weight the relative importance of noble metals and $\mathrm{pH}$ on the higher SRAT product yield stress for run 1A with this small set of data. Runs 2A and SB2-2 would be expected to yield identical results, since they were batched and processed nearly identically (2A had a discontinuous SRAT cycle with a 15 hour shut down period, whereas the SB2-2 SRAT cycle was run continuously from start to finish).

Table 5 summarizes the available Tank $8 / 40$ blend SRAT product data at $25^{\circ} \mathrm{C}$ including fits of the ramp-up flow curve data to the Bingham fluid model parameters. 
WSRC-TR-2001-00051

Page 20 of 53

Table 5. Summary of Tank 8/40 Blend SRAT Product Results at $25^{\circ} \mathrm{C}$

\begin{tabular}{cccccccc}
\hline Sample & $\begin{array}{c}\text { Total } \\
\text { Solids, } \\
\text { Wt. \% }\end{array}$ & $\begin{array}{c}\text { Insoluble } \\
\text { Solids, } \\
\text { Wt. \% }\end{array}$ & $\begin{array}{c}\text { \% Acid } \\
\text { Stoichi- } \\
\text { ometry }\end{array}$ & $\begin{array}{c}\text { Yield } \\
\text { Stress, } \\
\text { dynes/cm }\end{array}$ & $\begin{array}{c}\text { Plastic } \\
\text { Viscosity, } \\
\text { cP }\end{array}$ & $\begin{array}{c}\text { Supernate } \\
\text { pH }\end{array}$ & $\begin{array}{c}\text { Volume } \\
\text { Mean Particle } \\
\text { Size, microns }\end{array}$ \\
\hline 1B & 17.0 & not meas. & 137.5 & 43 & 8.4 & 6.75 & not meas. \\
3B & 16.9 & not meas. & 137.5 & 31 & 12.7 & 6.50 & not meas. \\
4B & 16.5 & 11.7 & 125 & 55 & 8.3 & 6.50 & not meas. \\
SB2-1 & 16.5 & 11.4 & 110 & 37 & 8.5 & 6.35 & not meas. \\
SB2-3 & 16.5 & 11.2 & 125 & 35 & 9.4 & 6.81 & 5.6 \\
SB2-4 & 18.7 & 11.2 & 290 & 43 & 8.6 & 6.33 & 5.5 \\
\hline
\end{tabular}

SB2-1 is the nominal Sludge Batch 2 (Macrobatch 3) case. The volume mean particle size of the starting blend sludge prior to processing was $4.8 \mu \mathrm{m}$. The other results are fairly consistent except for the rheogram results from the 3B sample. (The 3B scoping run was essentially duplicated by the SB2-1 variability study run. Since the SB2-1 run was made in round-the-clock operation mode, its results were taken as representative of the blend sludge with $125 \%$ acid stoichiometry.) Variations in $\mathrm{pH}$ were relatively minor in spite of processing differences.

Figure 10 compares runs 2B, SB2-1, and 4B, which had identical (nominal) noble metal loadings but different percent acid stoichiometries $(137.5 \%, 125 \%$, and $110 \%$ respectively). Figure 10 gives a clearer picture of the very weak effect of acid stoichiometry on apparent viscosity than the curve fit yield stress and consistency values in Table 5. 
WSRC-TR-2001-00051

Page 21 of 53

Figure 10. Effect of Acid Stoichiometry on SRAT Product Rheology

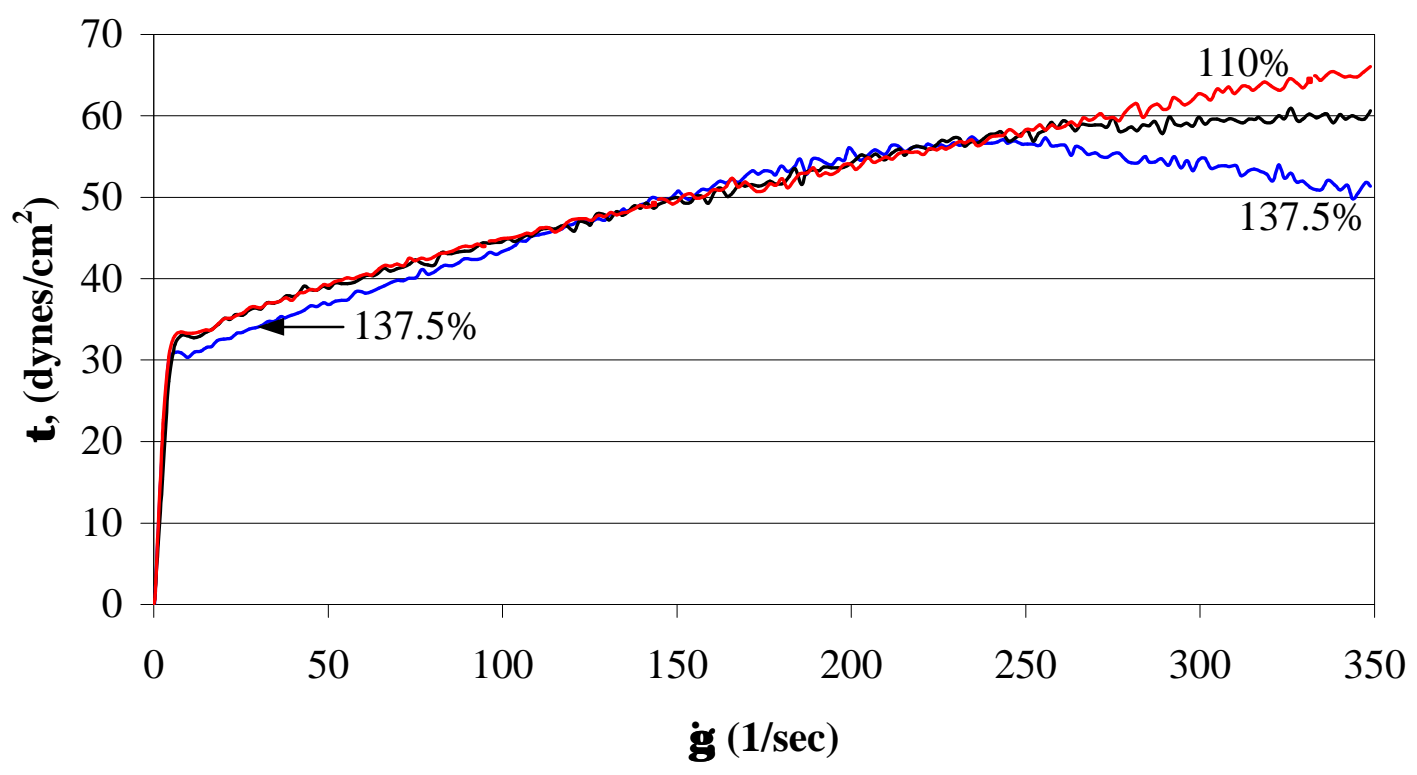

2B - Tank 8/40,137.5\% — SB2-1 - Tank 8/40, 125\% - 4B - Tank 8/40,110\%

Acid stoichiometry did not have a significant impact on the rheological properties of the three SRAT products, based on the data Figure 10. The phenomena above 275/sec are indicative of some of the problems encountered while measuring slurry rheology.

Figure 11 plots the ramp-up flow curves for four SRAT product samples at $25^{\circ} \mathrm{C}$. Runs "Elder137.5\%" and "Worst-290\%", had approximately double the concentrations of noble metals as the nominal run, SB2-1, or "125\%". See Koopman ${ }^{1}$ for details on the noble metals. SB2-3 was a run using HM levels of noble metals, "HM-125\%", which was identical to SB2-1 in nearly every other way. The SB2-1 and SB2-3 noble metal concentrations were similar overall, though not identical.

Noble metal concentrations correlated with changes in the rheological properties of Tank 8/40 blend SRAT product (assuming that acid stoichiometry did not per Figure 10). Samples with comparable concentrations of noble metals plotted closer to each other than to the samples with twice/half the concentration of noble metals in Figure 11. In general, the yield stress increased due to increasing noble metals concentration, but the consistency did not seem to be affected.

Wt. \% insoluble solids measurements were in the range $11.5 \pm 0.3 \%$ for all samples. This range was smaller than the two standard deviation uncertainty of wt. \% insoluble solids determinations. That has been estimated to be about $\pm 0.4 \%$. The $\mathrm{pH}$ of the four SRAT products was approximately neutral. Starting concentrations of mercury, manganese, etc. were identical in all four runs. The data in Figure 10 indicate that acid stoichiometry had at most a minor effect on the yield stress of this sludge. Consequently, all of these other factors were judged to be inadequate to produce the observed $30 \%$ change in yield stress. Conversely, the noble metals 
WSRC-TR-2001-00051

Page 22 of 53

were added in predetermined amounts to each test, so there was no question about the factor of two concentration differences being real. Noble metal concentration was ultimately selected as the most likely cause of the yield stress difference by a process of elimination.

Figure 11. Effect of Noble Metals on SRAT Product Rheology

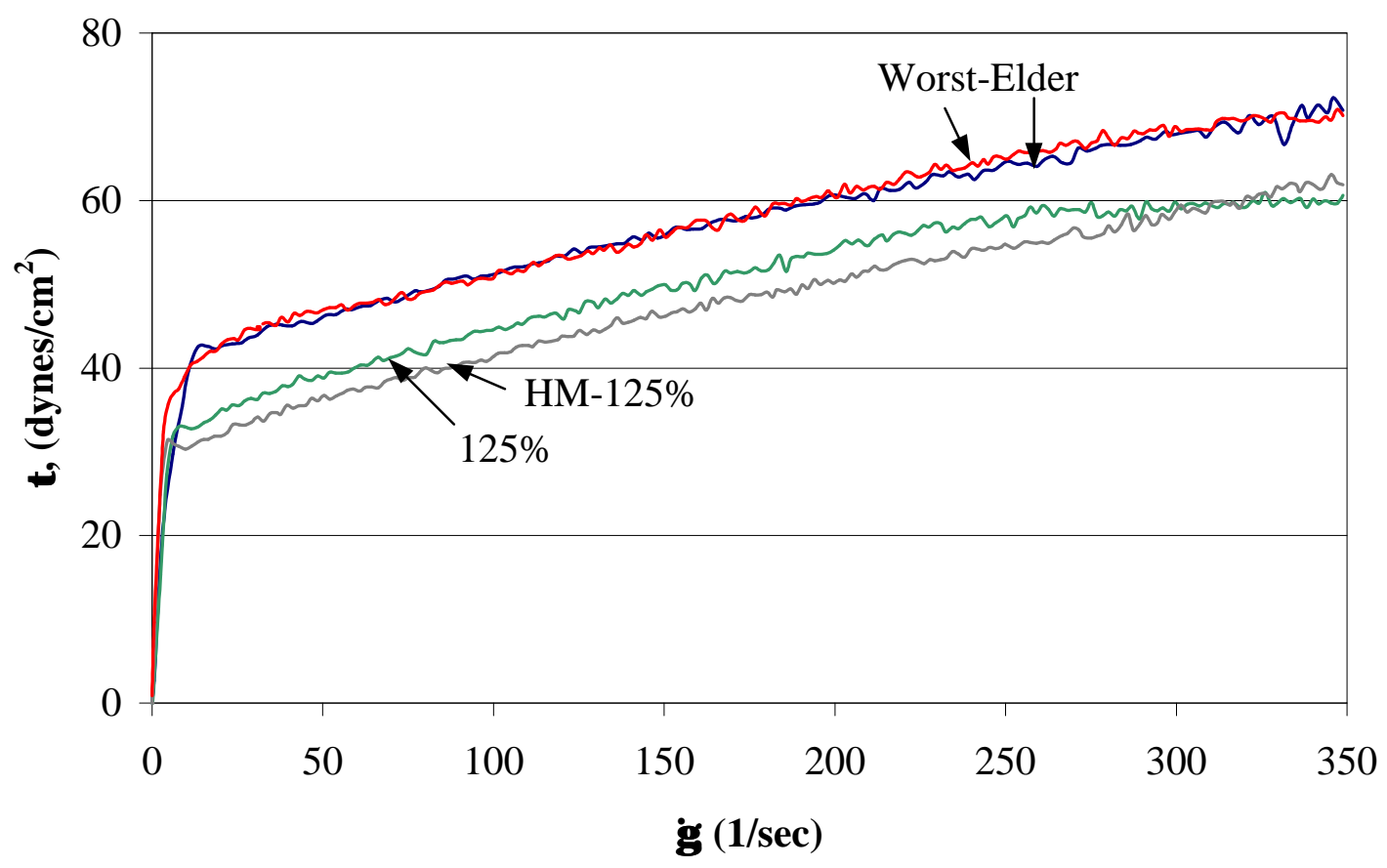

$\begin{aligned}- \text { 1B - Tank 8/40, Elder, 137.5\% } & \text { SB2-1 - Tank 8/40, 125\% } \\ \text { SB2-3 - Tank 8/40, HM-125\% } & \text { SB2-4 - Tank 8/40, Worst, 290\% }\end{aligned}$

The association of higher noble metal concentrations with increased yield stress was consistent with Figure 9 for Tank 40 SRAT product. The Tank 40 SRAT product with the highest yield stress also had higher noble metal concentrations. Unfortunately, other factors, such as $\mathrm{pH}$ and solids content, were not as constant in the Tank 40 data as in the blend data. The factor of two difference in Tank 40 yield stress was probably due to several effects acting together.

The precise mechanism linking higher noble metal concentrations to increased yield stress was not clear. Furthermore, SB2-4 may not belong in this group. The $290 \%$ acid stoichiometry (primarily formic acid) may have been responsible for a chemical attack on the solid sludge particles. This attack would then explain a reduction in volume mean particle diameter, $3.6 \mu \mathrm{m}$ vs. 5.5-5.6 $\mu \mathrm{m}$, leading to the increased yield stress relative to SB2-1 and SB2-3. This point is discussed further in Appendix I. Alternatively, the yield stress increase may have been due to the higher soluble solids concentration (though this was probably too small of an effect to explain the observation based on past observations). No similar observations, however, suggest that the 1B (137.5\%) data do not belong in a comparison of yield stress with SB2-1 and SB2-3. 
WSRC-TR-2001-00051

Page 23 of 53

\section{Sludge Simulant Results}

Various sludge simulant samples were available for analysis. The Sludge Batch 2 program started with fresh drums of Tank 8 simulant and Tank 40 simulant. Some of the Tank 40 simulant was trimmed with manganese (IV) oxide and nickel (II) chloride to more nearly match the ratios of $\mathrm{Mn} / \mathrm{Fe}$ and $\mathrm{Ni} / \mathrm{Fe}$ found in a sample of real Tank 40 sludge analyzed after the Tank 40 simulant had originally been prepared. The trimmed Tank 40 simulant was blended with some of the Tank 8 simulant to produce the Tank 8/Tank 40 blend used in the Macrobatch 3 flowsheet testing program ${ }^{1}$. A sample of the Optima Tank 51 (Macrobatch 1) simulant, that had been adjusted to approximate "Tank 42" (actually Sludge Batch 1B or Macrobatch 2) composition, was also available from unused sludge simulant from 1999 SRAT/SME testing. The following samples were tested:

- Tank 8 sludge simulant

- Tank 40 sludge simulant

- Tank 40 sludge simulant with added Mn and Ni

- Tank 8/Tank 40 blend sludge simulant

- $\quad$ Tank 42 sludge simulant (modified Tank 51 sludge simulant)

No additional adjustments were made to any of these samples. They were analyzed "as is". Consequently there were differences in wt. \% total and insoluble solids, and in supernate $\mathrm{pH}$, in addition to the differences in chemical composition. Table 6 summarizes the results obtained.

Table 6. Summary of Sludge Simulant Results at $25^{\circ} \mathrm{C}$

\begin{tabular}{ccccccc}
\hline Sample & $\begin{array}{c}\text { Total } \\
\text { Solids, } \\
\text { Wt. \% }\end{array}$ & $\begin{array}{c}\text { Insoluble } \\
\text { Solids, } \\
\text { Wt. \% }\end{array}$ & $\begin{array}{c}\text { Yield } \\
\text { Stress, } \\
\text { dynes/cm }\end{array}$ & $\begin{array}{c}\text { Plastic } \\
\text { Viscosity, } \\
\text { cP }\end{array}$ & pH & $\begin{array}{c}\text { Volume } \\
\text { Mean Particle } \\
\text { Size, microns }\end{array}$ \\
\hline Tank 8 & 14.9 & 12.5 & 7.4 & 4.8 & 9.8 & not meas. \\
Tank 40 & 15.9 & 12.6 & 79 & 11.8 & 11.2 & 6.63 \\
$\begin{array}{c}\text { Tank 40 w/ } \\
\text { added Mn, Ni }\end{array}$ & 16.5 & 13.5 & 125 & 15.6 & 11.2 & 6.92 \\
Tank 8/40 & 15.9 & 13.2 & 36 & 8.5 & 10.3 & 4.82 \\
Tank 42 & 17.0 & 13.9 & 15 & 5.6 & 12.8 & $3.81^{\dagger}$ \\
\hline
\end{tabular}

$\dagger$ From a sample following acid addition in the SRAT. For comparison, particle size was $4.04 \mu$ at the end of this SRAT cycle.

The flow curves from the shear rate ramp-up period for the five samples are shown in Figure 12. 
WSRC-TR-2001-00051

Page 24 of 53

Figure 12. Sludge Simulant Flow Curves at $25^{\circ} \mathrm{C}$

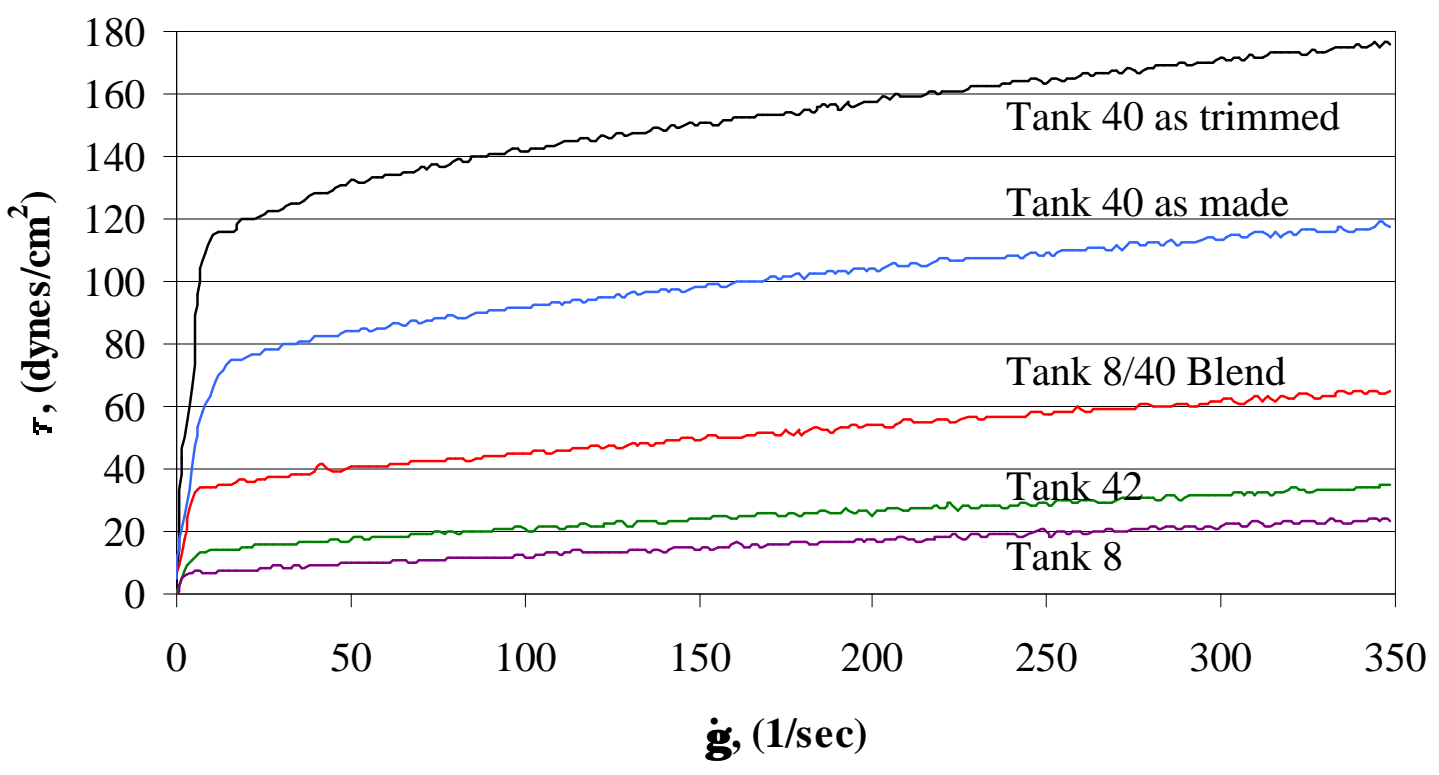

Tank 8/40 Blend — Tank 40 w/Mn, Ni — Tank $40 —$ Tank $42 —$ Tank 8

There was a dramatic difference in the rheological properties of the Tank 8 and Tank 40 sludge simulants produced at USC in 2000. This difference increased with the addition of trim chemicals to the Tank 40 sludge simulant. The most obvious preparation differences included:

- Tank 40 simulant hydrous ferric oxide precipitation occurred in the presence of about half as much previously precipitated manganese (IV) oxide as the Tank 8.

- Tank 40 hydrous ferric oxide was not co-precipitated with nickel hydroxide, while the Tank 8 simulant was co-precipitated with nickel hydroxide.

- Tank 8 and Tank 40 simulants were prepared by USC. Tank 42 simulant was originally prepared by Optima as Tank 51 simulant, then trimmed to approximate Tank 42 (Sludge Batch 1B).

- Addition of nickel chloride and additional manganese (IV) oxide to the Tank 40 simulant following synthesis at USC led to an increase in the apparent viscosity (most viscous flow curve in Figure 12).

The viscosity of the Tank 8/Tank 40 blend was intermediate to the two starting ingredients (Tank 8 simulant and Tank 40 simulant containing added nickel and manganese). Two simple mixing laws, equations [3] and [4] below, were examined for their ability to predict sludge blend rheology from the individual sludge component properties:

$$
a_{m i x}^{1 / 3}=x_{1} a_{1}^{1 / 3}+x_{2} a_{2}^{1 / 3}
$$


WSRC-TR-2001-00051

Page 25 of 53

$$
a_{\text {mix }}=a_{1}^{x_{1}} a_{2}^{x_{2}}
$$

Where:
$\mathrm{a}_{\operatorname{mix}}$
is the property to be averaged, e.g. $\tau_{0}, \eta$, or $\mu$
$a_{i} \quad$ is the property in initial phase $i$
$\mathrm{x}_{\mathrm{i}} \quad$ is the mass fraction of phase $\mathrm{i}$, about 0.50 for both Tank 8 and Tank 40

The second model, equation [4], suggested by the work of Olney and Carlson ${ }^{6}$, appeared to fit the Tank $8 / 40$ blend data fairly well, and better than the first model, or Kendall-Moore, equation ${ }^{7}$, equation [3]. The Olney and Carlson model tended to under-predict the measured blend viscosity, $\mu$, defined by $\tau / \gamma$, on the range from $100-200 \mathrm{sec}^{-1}$, by about $5 \%$. The KendallMoore equation tended to over-predict the blend viscosity by about $18 \%$.

The Olney and Carlson equation applied directly to the yield stress and plastic viscosity predicted 30 dynes $/ \mathrm{cm}^{2}$ and $8.6 \mathrm{cP}$, versus the measured values of 36 dynes $/ \mathrm{cm}^{2}$ and $8.5 \mathrm{cP}$. The Kendall-Moore equation applied directly to the yield stress and plastic viscosity predicted 42 dynes $/ \mathrm{cm}^{2}$ and $9.2 \mathrm{cP}$. Applying the mixing rules directly to the Bingham fluid model parameters is probably less appropriate than applying the rules to point values of the apparent viscosity, $\mu=\tau / \dot{\gamma}$, at specified shear rates. A mixture rheogram could be synthesized from a series of such predictions of $\mu$. These would could then be curve fit to whatever rheological model seemed appropriate. Rheograms synthesized from both models are compared to the raw blend data in Figure 13. Clearly the Olney and Carlson model gave the better approximation to the measured rheogram in this case. 
WSRC-TR-2001-00051

Page 26 of 53

Figure 13. Comparison of Predicted to Measured Flow Curves for Blended Sludge

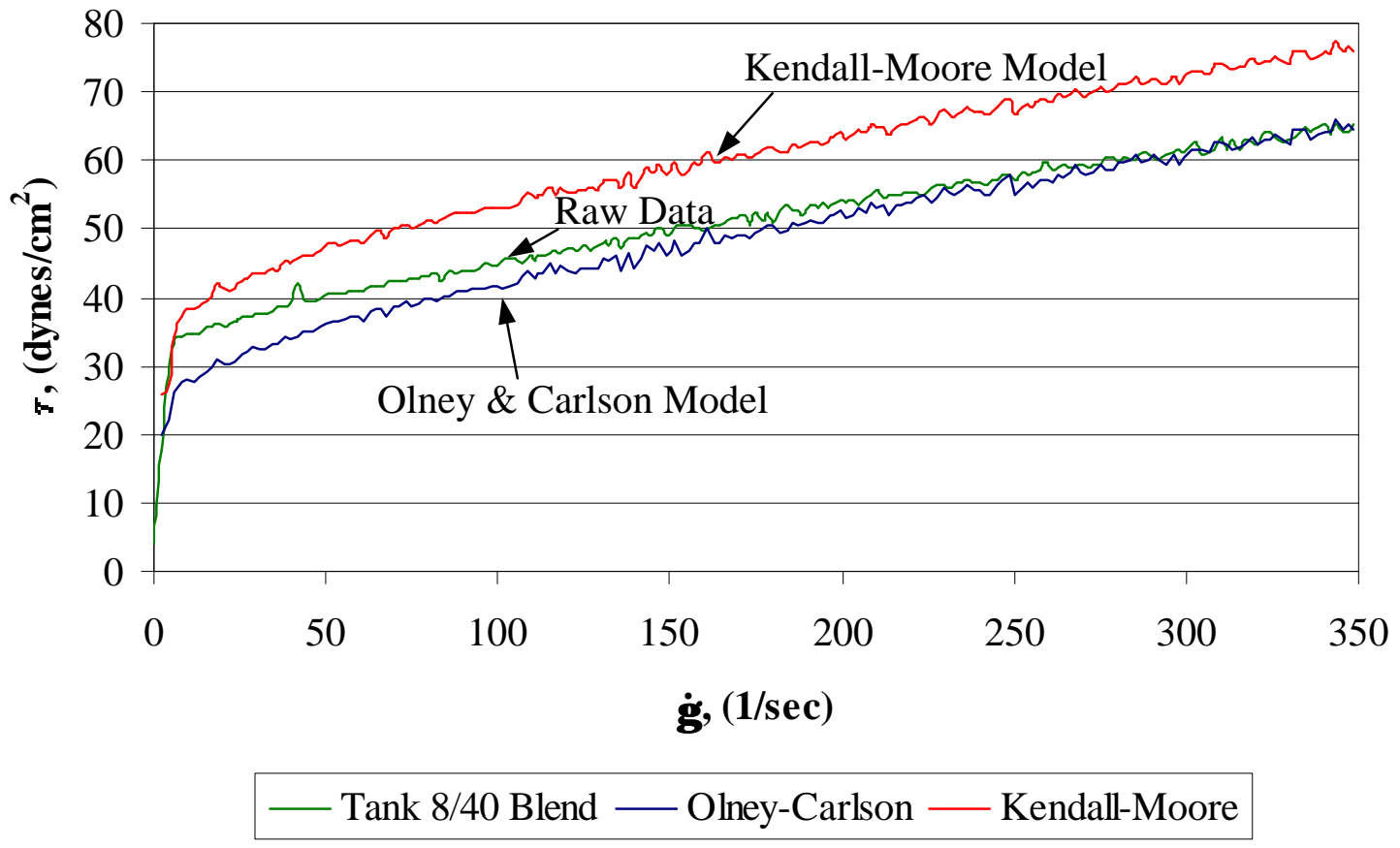

\section{Analysis of Weight \% Solids Effects}

SME Bingham plastic fluid parameters have historically been correlated with a model that permits interpolation of the data to the DWPF design basis limits of $25-150 \mathrm{dynes} / \mathrm{cm}^{2}$ for yield stress and 10-40 $\mathrm{cP}$ for the plastic viscosity. The preferred models, obtained from Shook and Roco $^{3}$, are:

$$
\begin{aligned}
& \tau_{o}=\frac{\exp ^{b_{1}{ }^{*} C}}{\left(1-C / C_{\text {max }}\right)} \\
& \eta=\frac{\exp ^{b_{2}{ }^{*}}}{\left(1-C / C_{\text {max }}\right)}
\end{aligned}
$$

Where:

$$
\begin{aligned}
& \tau_{\mathrm{o}} \quad=\text { yield stress from the Bingham fluid model fit, } \mathrm{dynes} / \mathrm{cm}^{2} \\
& \eta \quad=\text { plastic viscosity the Bingham fluid model fit, } \mathrm{cP} \\
& C \quad=\text { insoluble solids concentration, wt. } \% \\
& C_{\max }=\text { model parameter corresponding to maximum wt. } \% \text { insoluble solids } \\
& \left.b_{1}, b_{2}=\text { empirical parameters, (wt. } \%\right)^{-1}
\end{aligned}
$$

Eight correlations for Macrobatch 3 were generated, four for Tank 40 and four for Tank 8/40 blend. These include $\tau_{\mathrm{o}}(\mathrm{C})$ and $\eta(\mathrm{C})$ for Tank $40 \mathrm{SME}$ product at both $25^{\circ} \mathrm{C}$ and $50^{\circ} \mathrm{C}$, and $\tau_{\mathrm{o}}(\mathrm{C})$ and $\eta(\mathrm{C})$ for Tank $8 / 40$ blend SME product at both $25^{\circ} \mathrm{C}$ and $50^{\circ} \mathrm{C}$. Comparable historical data can be found in Marek ${ }^{4,5}$. The model parameters are summarized in Table 7. 
WSRC-TR-2001-00051

Page 27 of 53

Table 7. Parameters Governing Dependence on Wt. \% Insoluble Solids

\begin{tabular}{lcccc}
\hline \multicolumn{1}{c}{ SME Product } & $\begin{array}{c}\text { Temperature, } \\
{ }^{\circ} \mathrm{C}\end{array}$ & $\begin{array}{c}\text { Bingham } \\
\text { Parameter }\end{array}$ & $\begin{array}{c}\mathrm{C}_{\max }, \mathrm{Wt} . \% \\
\text { Insoluble }\end{array}$ & $\begin{array}{c}\mathrm{b}_{\mathrm{i}},(\mathrm{Wt} \text {. \% } \\
\text { Insoluble })^{-1}\end{array}$ \\
\hline Tank 40 & 25 & $\tau_{\mathrm{o}}$ & 56.9 & 0.088 \\
& & $\eta$ & 65.3 & 0.064 \\
Tank 40 & 50 & $\tau_{\mathrm{o}}$ & 52.5 & 0.080 \\
& & $\eta$ & 52.6 & 0.047 \\
Tank 8/40 & \multirow{2}{*}{25} & $\tau_{\mathrm{o}}$ & 57.3 & 0.097 \\
& & $\eta$ & 56.8 & 0.048 \\
Tank 8/40 & 50 & $\tau_{\mathrm{o}}$ & 54.2 & 0.097 \\
& & $\eta^{\dagger}$ & 51.8 & 0.037 \\
\hline
\end{tabular}

$\dagger$ - Only the best five points were included in the fit.

The model parameters were obtained using the Regression Wizard in SigmaPlot 4.01. The above form for a model equation was programmed as a User-Defined model. According to the physical basis for the model, $\mathrm{C}_{\max }$ for the $\tau_{\mathrm{o}}$-fit and $\mathrm{C}_{\max }$ for the $\eta$-fit should be the same for a given fluid at a given temperature. Three of the four data sets had fairly close agreement between the separately fitted $C_{\max }$ values. An attempt was made to fit both $\tau_{\mathrm{o}}$ and $\eta$ simultaneously with a single, shared $C_{\max }$, but regression convergence was not obtained. Such a simultaneous fit should be possible, but no further time was spent pursuing it. The value of $\mathrm{C}_{\max }$ depends greatly on the point(s) with the highest wt. \% insoluble solids. The rheogram(s) with the highest wt. \% insoluble solids were also the most difficult to measure accurately.

Some historical results ${ }^{4,5}$ are given in Table 8 for comparison, however the original parameters for the TAR 970056 and DWPF-0005 work were correlated with wt. \% total solids instead of wt. $\%$ insoluble solids. (The original theoretical model was developed for the volume fraction of insoluble matter, so the wt. \% insoluble solids is the appropriate substitute, assuming volume fraction of insoluble matter is linearly proportional to the wt. \% insoluble solids. The DWPF0005 data was refit using the wt. \% insoluble solids for inclusion below.) The FA-10 yield stress data was so temperature insensitive that it was fit to a single model ${ }^{5}$. 
WSRC-TR-2001-00051

Page 28 of 53

Table 8. Historical Parameters Fitting the Bingham Fluid Properties of SME Products

\begin{tabular}{lcccc}
\hline SME Product & Temperature, ${ }^{\circ} \mathrm{C}$ & $\begin{array}{c}\text { Bingham } \\
\text { Parameter }\end{array}$ & $\begin{array}{c}\mathrm{C}_{\max }, \mathrm{Wt} . \%, \\
\text { Total or Insoluble }\end{array}$ & $\mathrm{b}_{\mathrm{i}},(\mathrm{Wt} \text { \% })^{-1}$ \\
\hline FA-10 $^{\dagger}$ & $25 / 50$ & $\tau_{\mathrm{o}}$ & 58.7 & 0.086 \\
& 25 & $\eta$ & 56.6 & 0.047 \\
TAR 970056 $^{\ddagger}$ & 50 & $\eta$ & 57.3 & 0.044 \\
& 25 & $\tau_{\mathrm{o}}$ & 65.4 & 0.071 \\
TAR 970056 $^{\ddagger}$ & 25 & $\eta$ & 66.3 & 0.035 \\
& 50 & $\tau_{\mathrm{o}}$ & 67.5 & \\
DWPF-0005 $^{\ddagger}$ & 50 & $\eta$ & 72.1 & 0.075 \\
& 25 & $\tau_{\mathrm{o}}$ & 65.2 & 0.034 \\
DWPF-0005 $^{\dagger}$ & 25 & $\eta$ & 61.9 & 0.066 \\
& 25 & $\tau_{\mathrm{o}}$ & 41.1 & 0.020 \\
DWPF-0005 $^{\dagger}$ & 25 & $\eta$ & 40.3 & 0.083 \\
& 50 & $\tau_{\mathrm{o}}$ & 41.0 & 0.019 \\
& 50 & $\eta$ & 40.2 & 0.085 \\
& & & & 0.002 \\
\hline
\end{tabular}

$\dagger$ - fit using wt. \% insoluble solids

+ fit using wt. \% total solids

The data for Macrobatch 3 simulant SME products was equally well fit using a simple exponential function, $\mathrm{Ae}^{\mathrm{bx}}$, but no scientific basis was found for this model. Figure 14 shows the fit of equation [5] to the calculated yield stress values at $25^{\circ} \mathrm{C}$ for the Tank $8 / 40 \mathrm{SME}$ product samples. A yield stress of 150 dynes $/ \mathrm{cm}^{2}$ was reached at $39.6 \mathrm{wt}$. \% insoluble solids. This corresponds to about 44.9 wt. $\%$ total solids.

The wt. \% total solids for nominal SB2-1 SME product was correlated to the wt. \% insoluble solids by

$$
\text { (wt. \% total solids })=1.191 *(\text { wt. } \% \text { insoluble solids })-2.3086
$$

with $\mathrm{R}^{2}$ of 0.9995 . The negative value of the intercept suggests some error or bias in the raw wt. $\%$ data. The equation should be used only within the range of the original data, Table 1. Similar nearly linear relationships have been obtained historically for simulated SME products ${ }^{4,5}$. 
WSRC-TR-2001-00051

Page 29 of 53

Figure 14. Yield Stress of Tank 8/40 SME Product at $25^{\circ} \mathrm{C}$

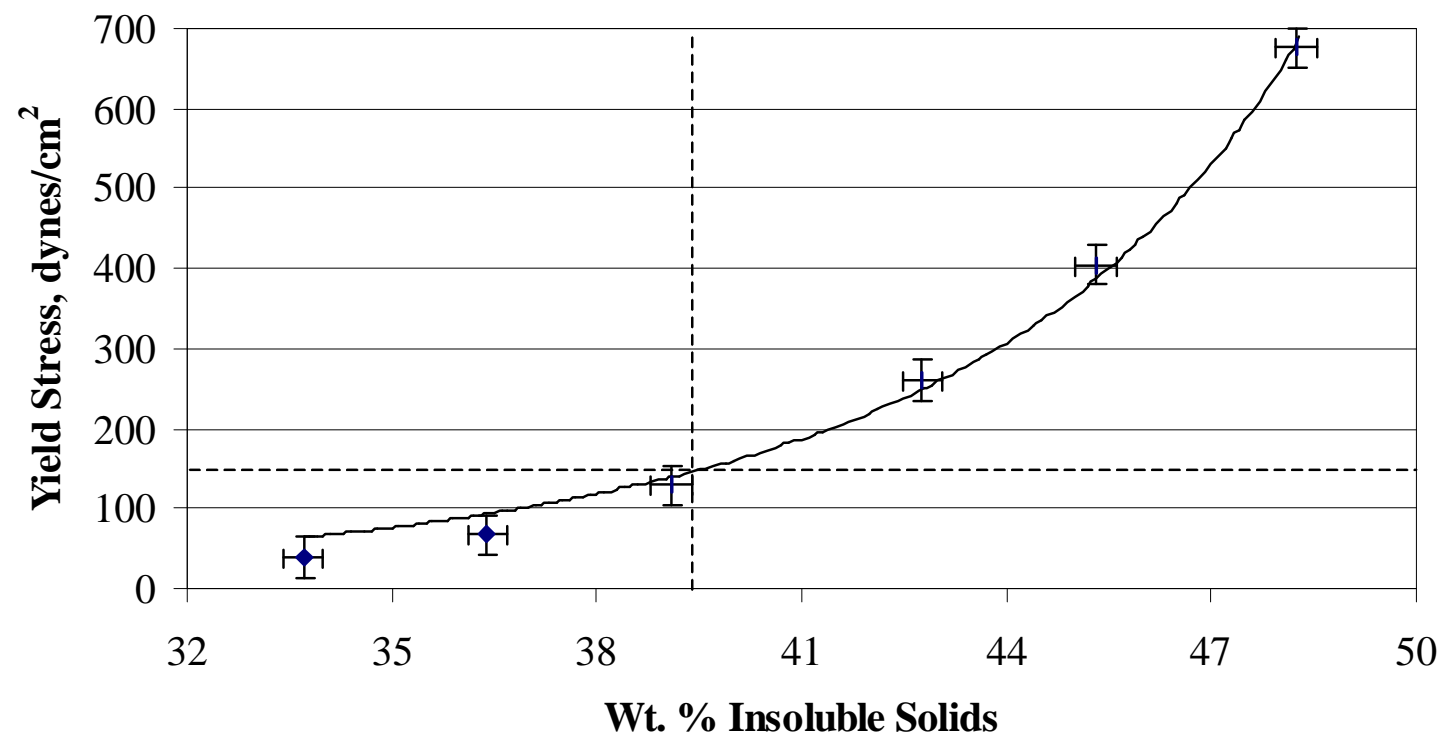

Error bars for yield stress data in Figure 14 indicate $\pm 0.3 \mathrm{wt}$. $\%$ and \pm 25 dynes $/ \mathrm{cm}^{2}$. It appeared that a given sample gave a more reproducible yield stress result than that, however results from similar Tank 8/40 SME product samples obtained in a separate study show differences of this magnitude. Figure 15 plots the calculated plastic viscosities for the same samples using equation [6].

Figure 15. Plastic Viscosity of Tank 8/40 SME Product at $25^{\circ} \mathrm{C}$

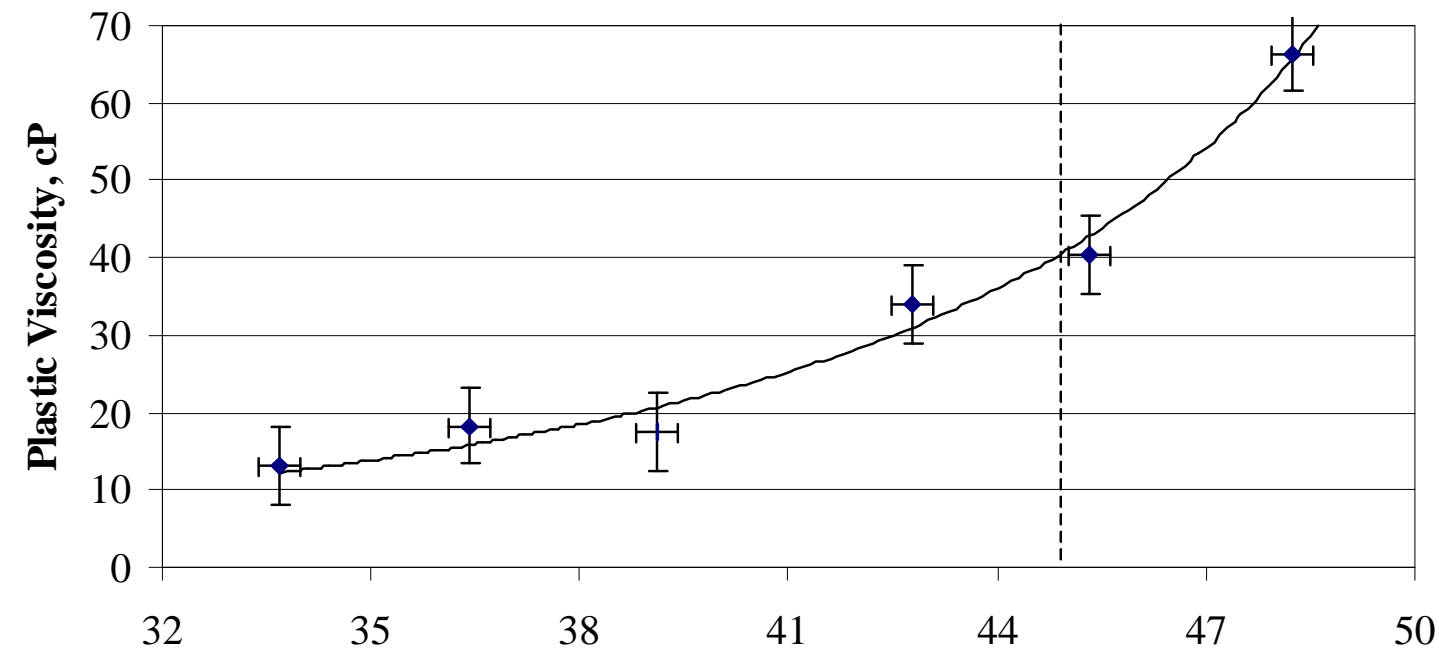

Wt. \% Insoluble Solids

Error bars for plastic viscosity data in Figure 15 indicate $\pm 0.3 \mathrm{wt}$. $\%$ and $\pm 5 \mathrm{cP}$. The $\pm 5 \mathrm{cP}$ derived from the experimental observation that it was difficult to reproduce a plastic viscosity 
WSRC-TR-2001-00051

Page 30 of 53

within this range from the same sample on repeated trials. The plastic viscosity exceeded the design basis at $44.8 \mathrm{wt}$. \% insoluble solids (about 51 wt. \% total solids).

Figures 16 and 17 give the comparable results for Tank 8/40 SME product at $50^{\circ} \mathrm{C}$.

Figure 16. Yield Stress of Tank 8/40 SME Product at $50^{\circ} \mathrm{C}$

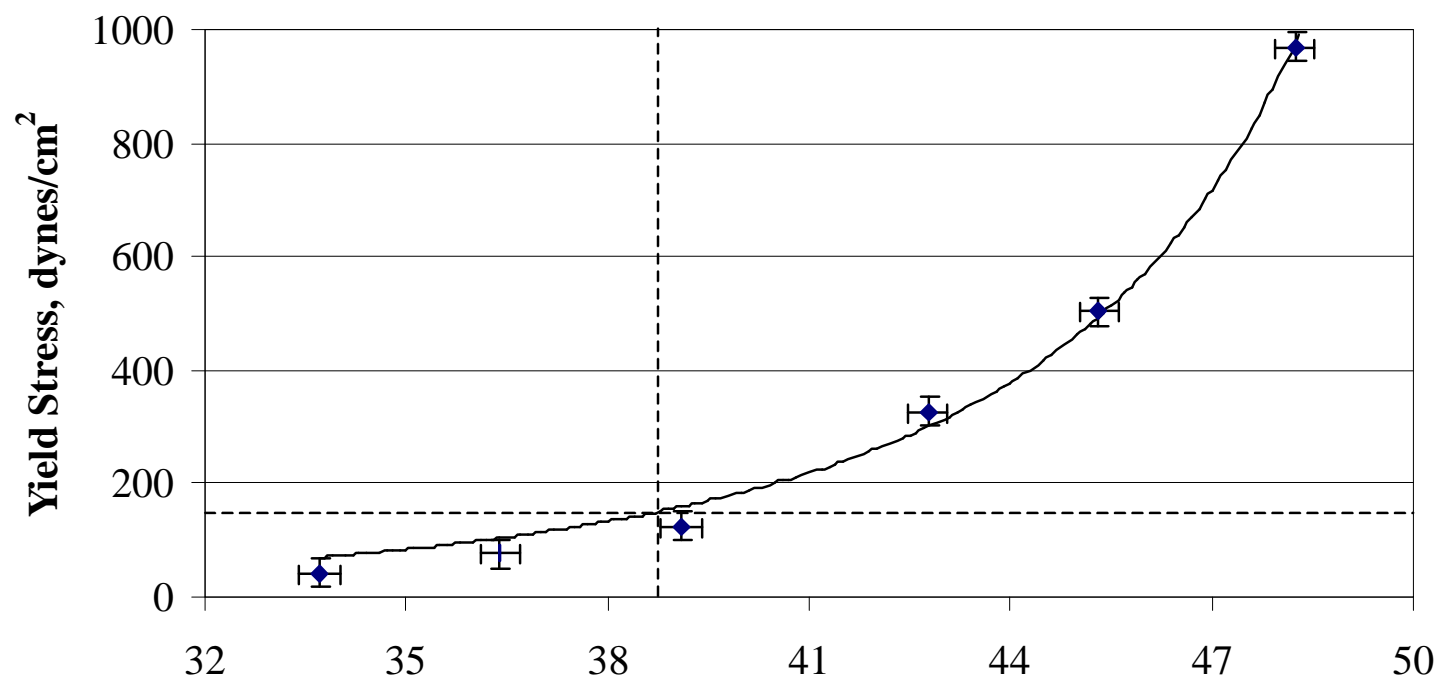

Wt. \% Insoluble Solids

Figure 17. Plastic Viscosity of Tank 8/40 SME Product at $50^{\circ} \mathrm{C}$

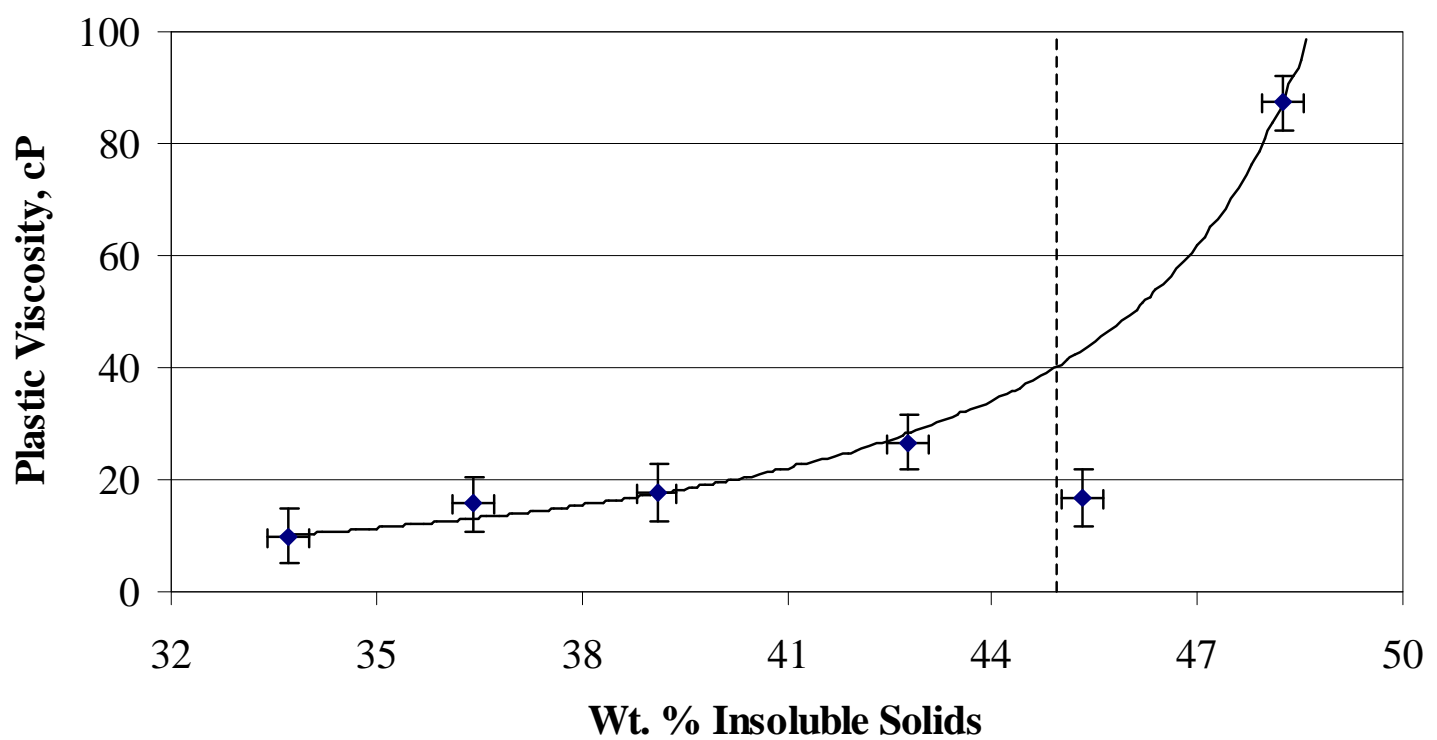

The plastic viscosity value at 45.3 wt. \% was not included in the fit of the model equation. Error bars in both figures were set per the discussion for Figures 14 and 15. The yield stress exceeded 150 dynes $/ \mathrm{cm}^{2}$ at 38.7 wt. \% insoluble solids (43.8 wt. \% total solids). The plastic viscosity exceeded $40 \mathrm{cP}$ at 44.9 wt. \% insoluble solids (51.2 wt. \% total solids). 
WSRC-TR-2001-00051

Page 31 of 53

Figures 18 and 19 show the Bingham fluid model parameters for the Tank 40 SME product at $25^{\circ} \mathrm{C}$ along with the model equation fit to equations [5] and [6] respectively.

Figure 18. Yield Stress of Tank $40 \mathrm{SME}$ Product at $25^{\circ} \mathrm{C}$

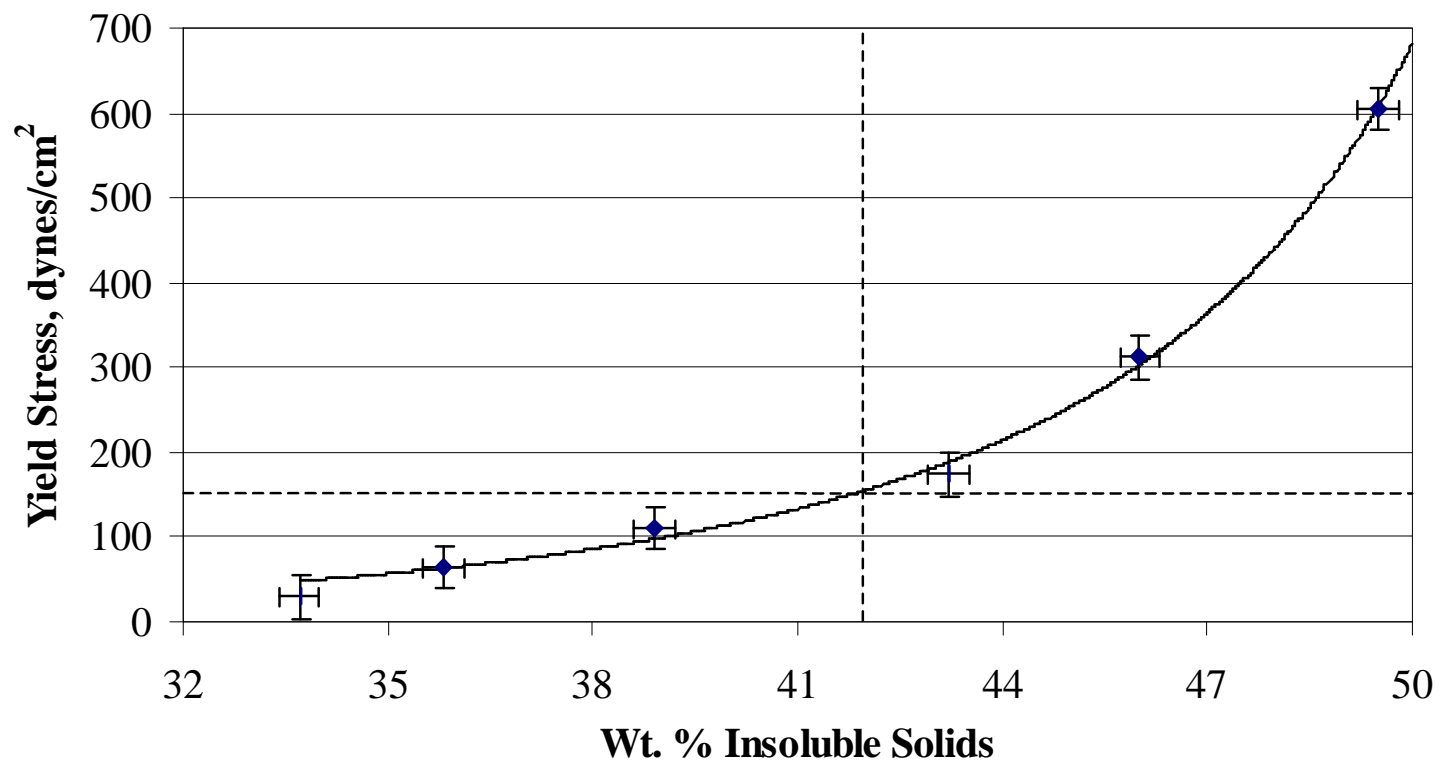

Figure 19. Plastic Viscosity of Tank 40 SME Product at $25^{\circ} \mathrm{C}$

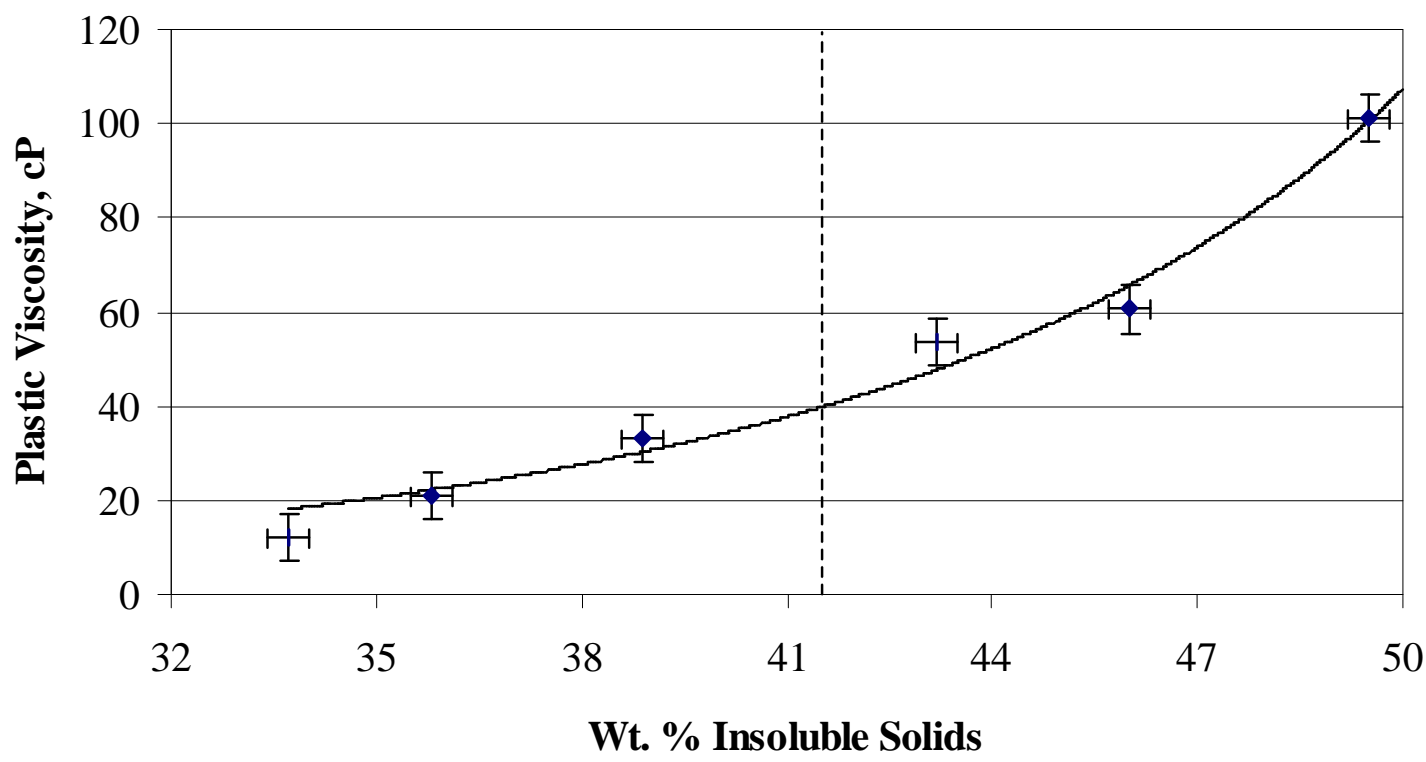

Error bars in both figures are set per the discussion for Figures 14 and 15. The yield stress exceeded 150 dynes $/ \mathrm{cm}^{2}$ at $41.8 \mathrm{wt}$ \% insoluble solids (48.2 wt. \% total solids). The plastic viscosity exceeded $40 \mathrm{cP}$ at $41.5 \mathrm{wt}$ \% $\%$ insoluble solids (47.9 wt. \% total solids). Solids correlated as: 
(wt. $\%$ total solids $)=1.1756 *($ wt. $\%$ insoluble solids $)-0.9363$

with an $\mathrm{R}^{2}$ of 0.9972 for the Tank 40 SME product. Again, the negative intercept is not physically realistic. Usage of the model should be limited to the range over which the data was taken, Table 2.

Figures 20 and 21 give equivalent information for the Tank $40 \mathrm{SME}$ product samples at $50^{\circ} \mathrm{C}$.

Figure 20. Yield Stress of Tank 40 SME Product at $50^{\circ} \mathrm{C}$

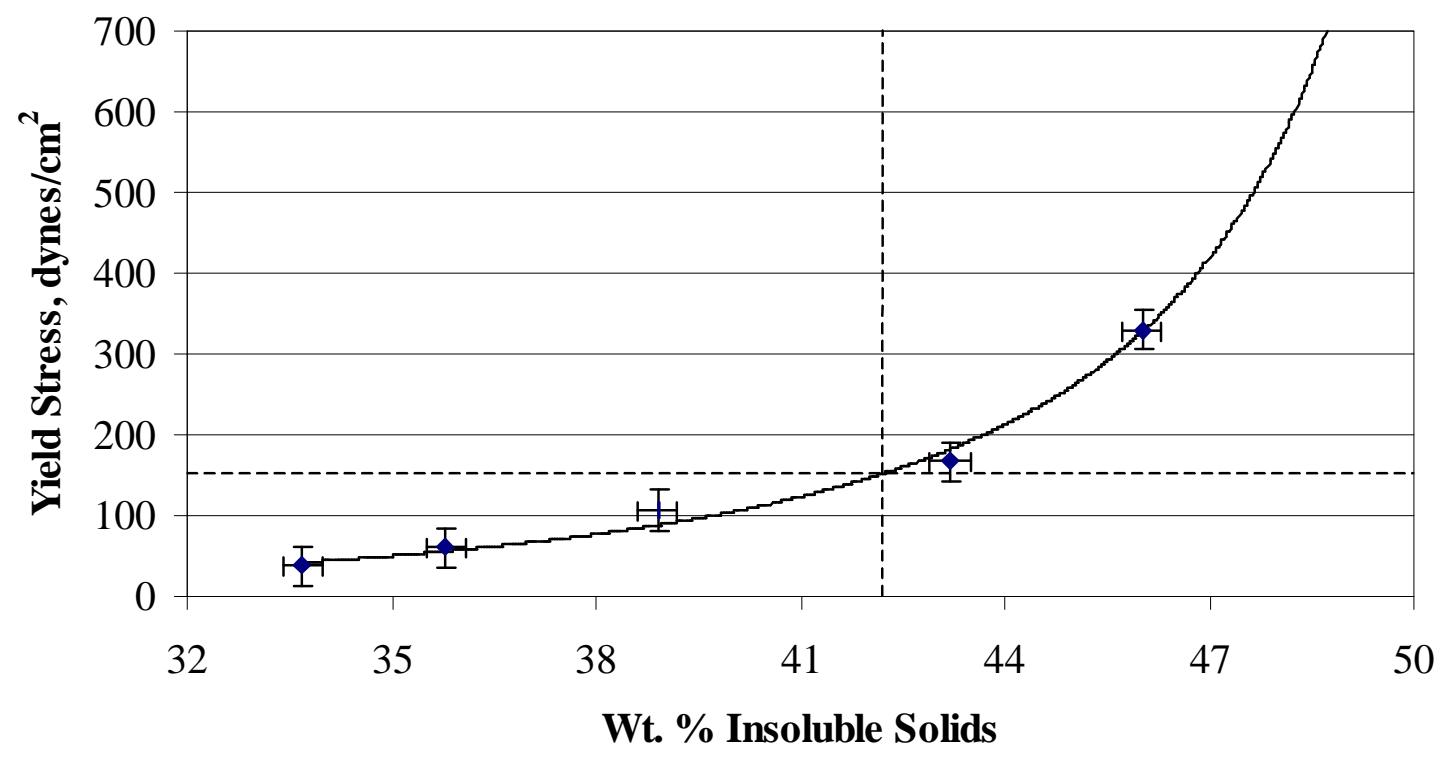


WSRC-TR-2001-00051

Page 33 of 53

Figure 21. Plastic Viscosity of Tank $40 \mathrm{SME}$ Product at $50^{\circ} \mathrm{C}$

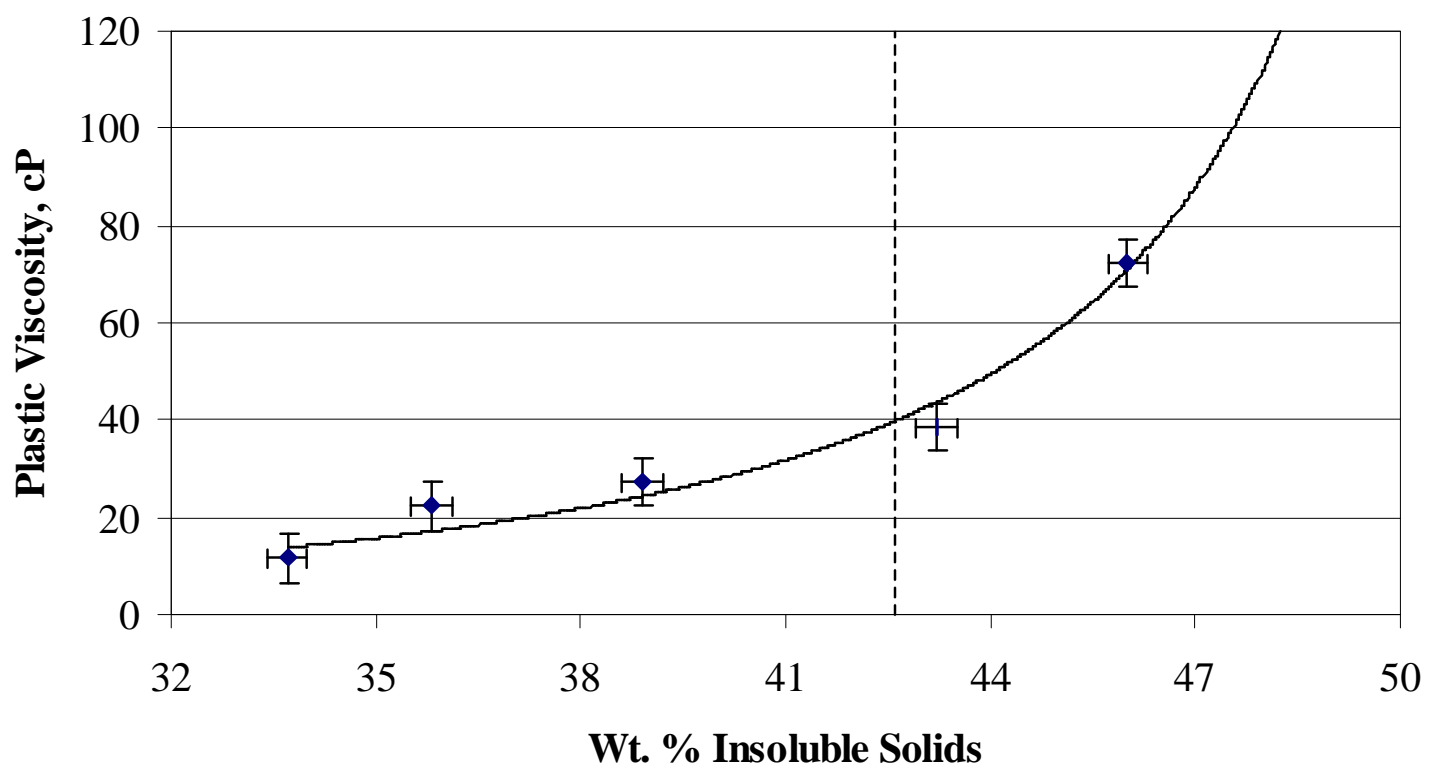

Error bars in Figures 20 and 21 are set per the discussion for Figures 14 and 15. The yield stress exceeded 150 dynes $/ \mathrm{cm}^{2}$ at $42.1 \mathrm{wt} . \%$ insoluble solids (48.6 wt. $\%$ total solids). The plastic viscosity exceeded $40 \mathrm{cP}$ at $42.6 \mathrm{wt}$. \% insoluble solids (49.2 wt. \% total solids). The $\mathrm{R}^{2}$ values for the eight $\left(b_{i}, C_{\max }\right)$, fit to equations [5] and [6], ranged from 0.969 to 0.997 , with the four lower values associated with the plastic viscosity data and the four higher values associated with the yield stress.

One dramatic effect that was observed in processing the sludge through to SME product was the elimination of the Tank 40 to Tank 8/40 blend initial difference in yield stress. As described above, the Tank 40 sludge used in the testing had roughly an order of magnitude higher yield stress than the Tank 8 raw sludge, and about a factor of three greater yield stress than the Tank $8 / 40$ blend. Much of the difference was removed during the SRAT cycle processing. (Some speculation as to how SRAT processing may have effected rheology through particle size is given at the end of Appendix I). The addition of frit in the SME cycle further impacted the difference. Figure 22 shows the rheograms at $25^{\circ} \mathrm{C}$ for two pairs of SME products with essentially identical wt. \% insoluble solids. 
WSRC-TR-2001-00051

Page 34 of 53

Figure 22. Comparison of Typical Tank 40 and Tank 8/40 SME Product Flow Curves

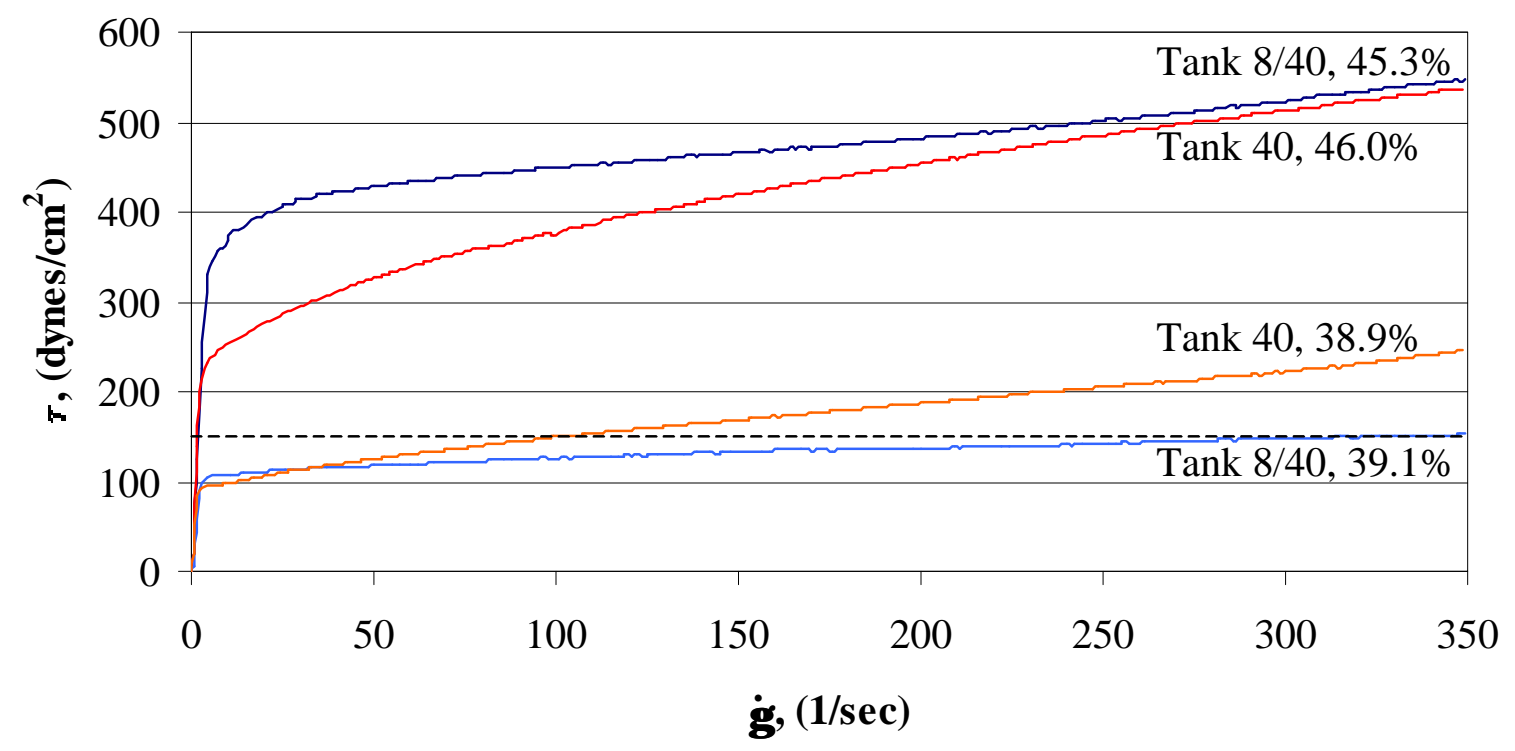

Tank $8 / 40,45.3 \% —$ Tank $40,46.0 \% —$ Tank $8 / 40,39.1 \% —$ Tank $40,38.9 \%$

The Tank 40 SME yield stress was somewhat lower in both cases. Variations in the plastic viscosity left one pair with a more fluid Tank 40 SME product and the other pair with a more fluid Tank 8/40 blend SME product at higher shear rates. Any sweeping statement such as "more viscous sludge will produce a more viscous SME product" could clearly not be supported by the data obtained in this study.

Figure 23 compares the Tank 40 and Tank 8/40 blend SME product yield stress data at $25^{\circ} \mathrm{C}$ to each other with the corresponding models from equation [5] superimposed. Figure 24 compares the plastic viscosities for the same two SME products with the corresponding models from equation [6] superimposed. 
WSRC-TR-2001-00051

Page 35 of 53

Figure 23. Yield Stress of Tank 40 vs. Tank 8/40 SME Product at $25^{\circ} \mathrm{C}$

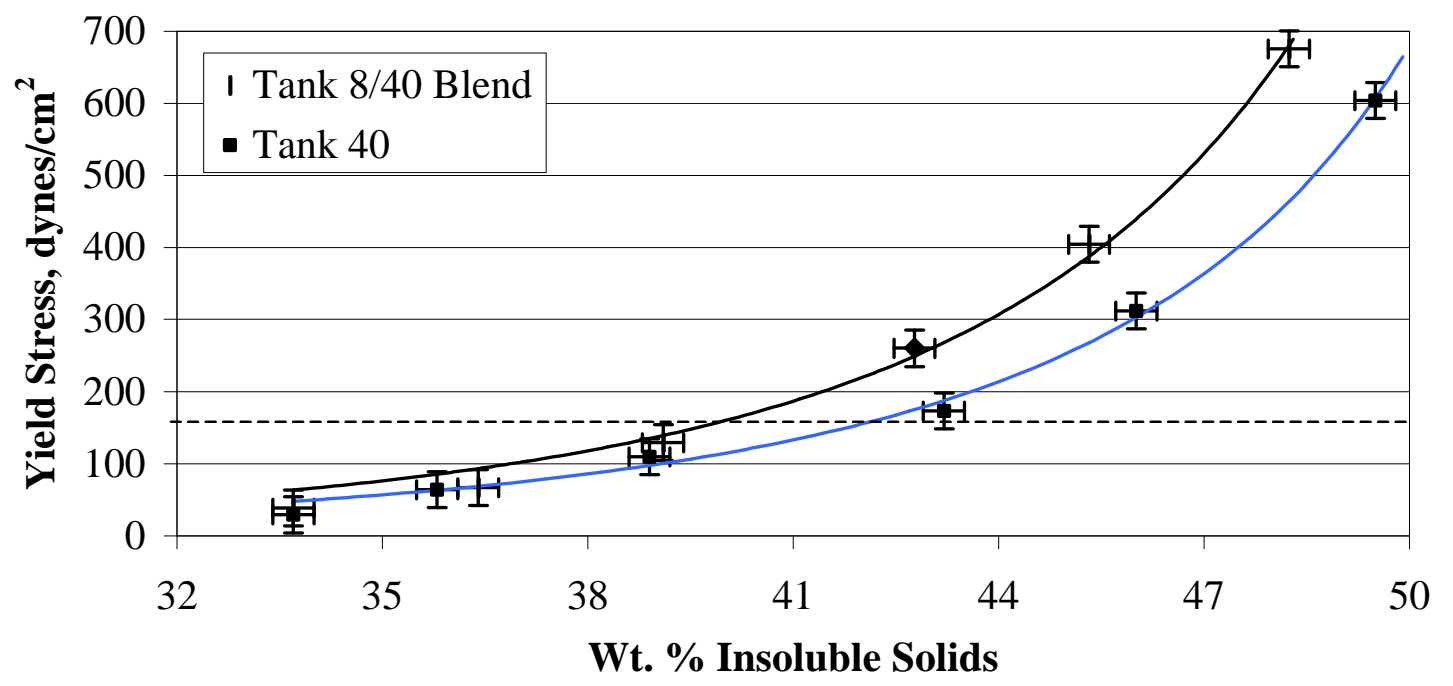

Figure 24. Plastic Viscosity of Tank 40 vs. Tank 8/40 SME Product at $25^{\circ} \mathrm{C}$

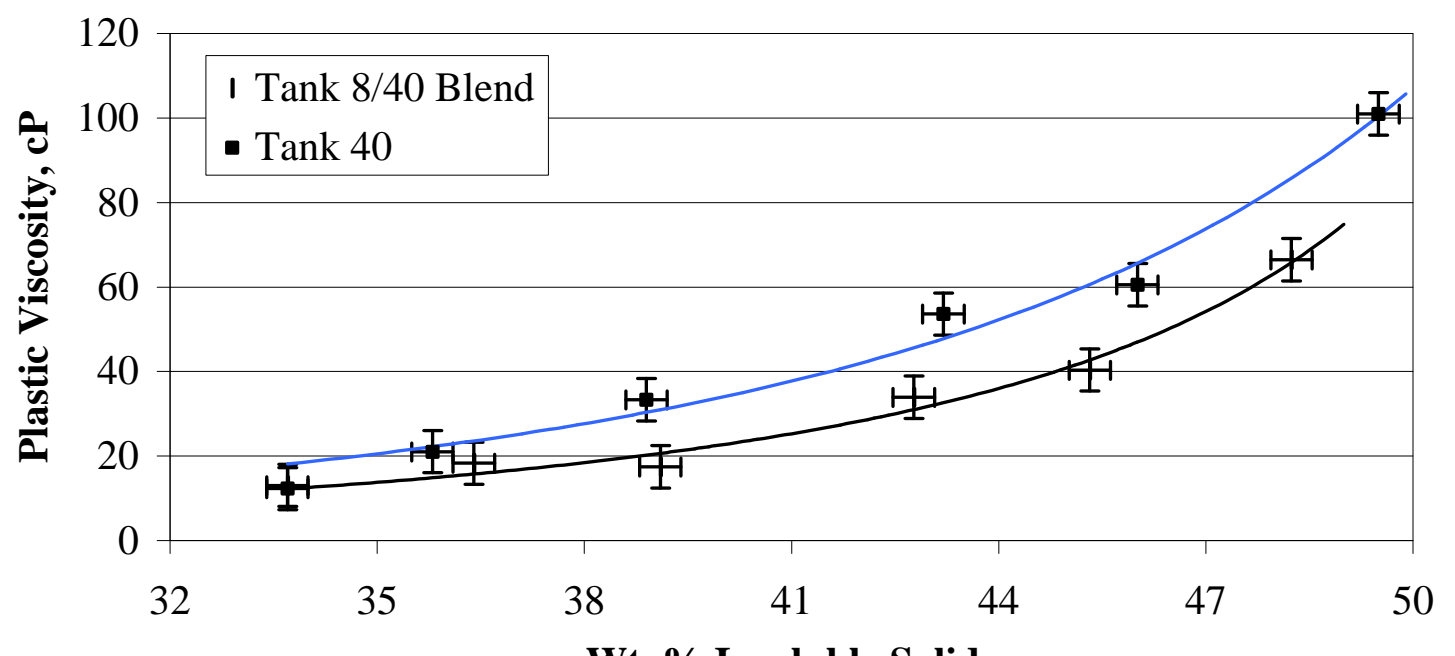

The conclusion from Figures 23 and 24 is that Tank 8/40 blend SME product has a higher yield stress and a lower plastic viscosity than the Tank 40 SME product at a given wt. \% insoluble solids over the range of data obtained at $25^{\circ} \mathrm{C}$.

Figures 25 and 26 are equivalent to Figures 23 and 24 but with the $50^{\circ} \mathrm{C}$ data. 
WSRC-TR-2001-00051

Page 36 of 53

Figure 25. Yield Stress of Tank 40 vs. Tank 8/40 SME Product at $50^{\circ} \mathrm{C}$

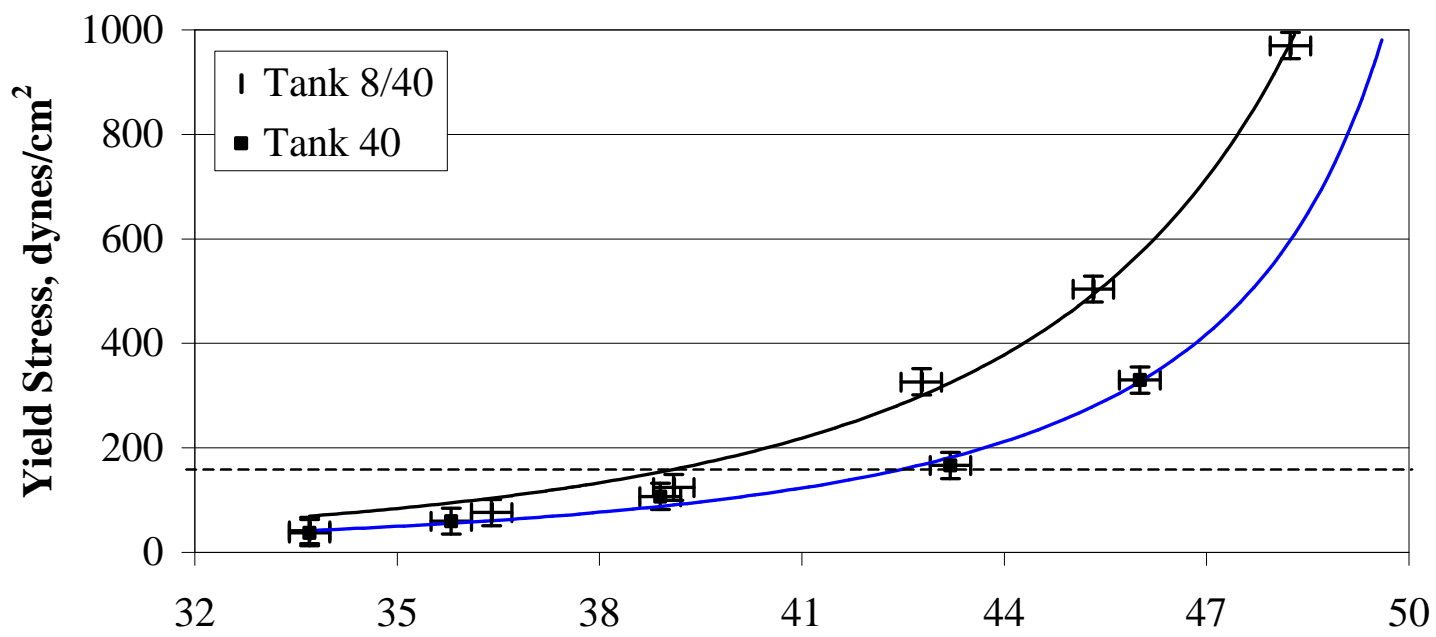

Wt. \% Insoluble Solids

Figure 26. Plastic Viscosity of Tank 40 vs. Tank 8/40 SME Product at $50^{\circ} \mathrm{C}$

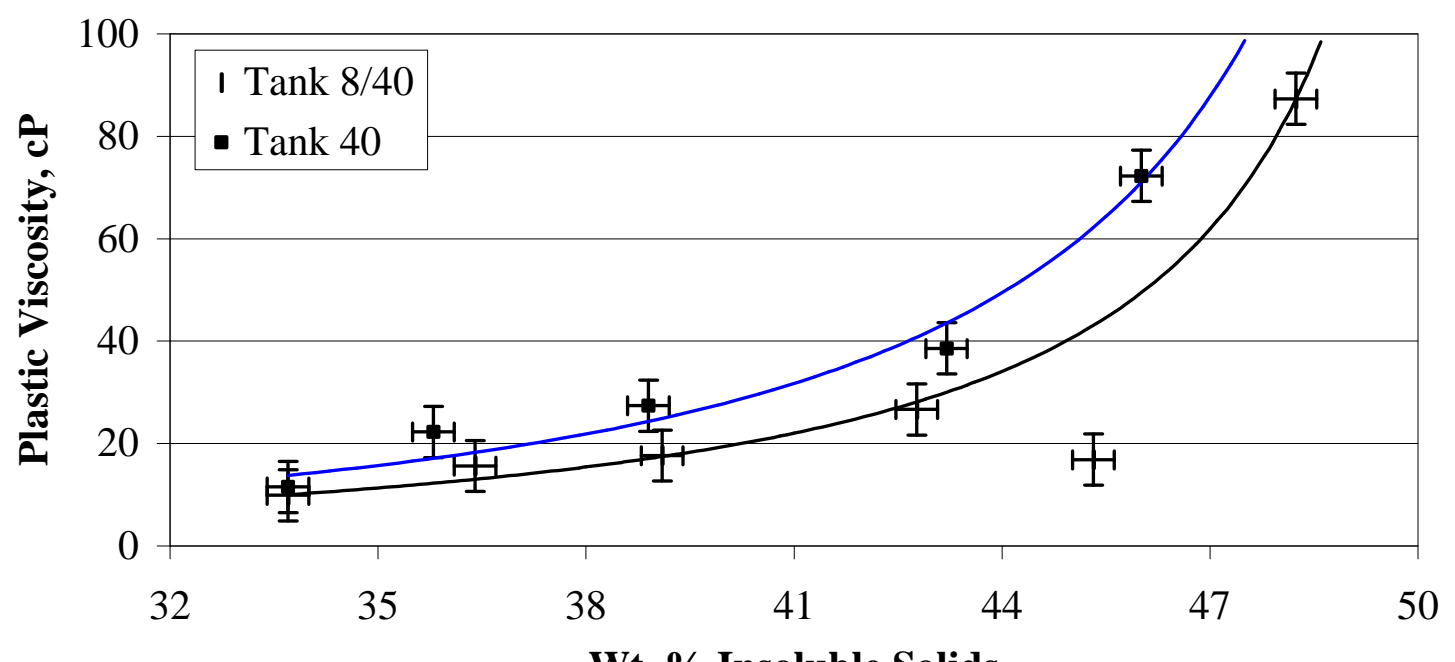

The blend SME product has a higher yield stress and a lower plastic viscosity than the Tank 40 SME product at a given wt. $\%$ insoluble solids at $50^{\circ} \mathrm{C}$ as well as at $25^{\circ} \mathrm{C}$.

\section{SUMMARY}

Simulated slurries of washed sludge, SRAT product, and SME product were rheologically characterized and compared. Rheological data was fit to the two parameter Bingham plastic fluid model, equation [2]. Sludge and SRAT product yield stresses and plastic viscosities were of comparable magnitude. Yield stresses ranged from 25-125 dynes $/ \mathrm{cm}^{2}$. Plastic viscosities 
WSRC-TR-2001-00051

Page 37 of 53

ranged from 5-17 cP. SME product Bingham plastic fluid parameters covered broader ranges. Yield stresses ranged from 30-1000 dynes $/ \mathrm{cm}^{2}$. Plastic viscosities ranged from $10-100 \mathrm{cP}$.

DWPF design bases upper limits were exceeded at relatively low wt. \% total solid concentrations (generally about 44-48\%). Accurate measurements of SME product rheograms were complicated by the nature of the samples, which did not remain homogeneous over the twelve minute cycle time of the rheometer. Consequently, yield stress values were obtained with a higher degree of confidence than plastic viscosity values. If real SME product rheology matches simulant rheology, then it may be necessary to reduce the wt. \% total solids in the melter feed.

Bingham fluid model parameters were correlated well with a model that substituted wt. \% insoluble solids for the volume fraction of insoluble solids. SRAT product model parameters from the testing seemed to indicate that \% acid stoichiometry was a non-factor, but that noble metals were a factor. Higher concentrations of noble metals, or a side effect of their presence during processing, appeared to lead to more viscous SRAT products. 
WSRC-TR-2001-00051

Page 38 of 53

\section{REFERENCES}

1. D. C. Koopman, Sludge Batch 2 (Macrobatch 3) Flowsheet Studies with Simulants (U), WSRC-TR-2000-00398, Revision 0,

2. C. W. Hsu, Revision 1 of Batch 1 Sludge Composition for Integrated Cold Runs in the Defense Waste Processing Facility, WSRC-RP-92-1056, February, 1995.

3. C. A. Shook and M. C. Roco, Slurry Flow - Principles and Practice, ButterworthHeinemann, 1991, page 62.

4. J. C. Marek, Rheology Measurements of Simulated Slurry Mix Evaporator Material (U), WSRC-TR-97-00343, October 17, 1997.

5. J. C. Marek, Rheology of SME Product From Alternative Sludge-only Flowsheet with Batch One Sludge Simulant (U), WSRC-TR-96-0179, June 26, 1996.

6. Olney and Carlson, Chem. Eng. Progr., 43, 473 (1947).

7. Kendall and Monroe, J. Am. Chem. Soc., 39, 1787, (1917). 
WSRC-TR-2001-00051

Page 39 of 53

\section{APPENDIX I：PARTICLE SIZE DISTRIBUTION RESULTS}

The eleven pages that follow give the particle size distribution printouts for the eleven samples submitted to the Analytical Development Section. A short discussion of some observations related to the particle size distributions follows. A few notes are in order as to the interpretation of the numbers on the MicroTrac printouts.

The lower left portion of the printout has a table with three columns labeled SIZE, \%PASS, and $\%$ CHAN. The \%PASS scale, also the solid line on the plot, gives the integral, or cumulative, particle size distribution, $0-100 \%$. The \%CHAN scale gives the derivative or frequency distribution. The \%PASS is the running total of the \% CHAN data. The numbers in the SIZE column are the upper edges of the measurement channels. So \%CHAN of $26.32 \%$ at SIZE 176.0 means that $26.32 \%$ of the particles fell between 124.5 microns and 176.0 microns. The \%CHAN numbers are plotted as the bar graph. The bars are approximately centered in the micron window for that channel. The smallest channel is from 0.688 microns to 0.972 microns. Particles below 0.688 microns are not counted. The first entry below this table, Distribution: Volume, indicates that the program is generating the volume distribution in the \% CHAN column and on the bar graph (as opposed to an area or number distribution).

At the top center of the printout is a useful summary box containing five quantities, mv, mn, ma, cs, and sd. These are defined as follows:

mv mean diameter of the distribution weighted by approximate particle volume.

$\mathrm{mn} \quad$ mean diameter of the distribution weighted by number of particles.

ma mean diameter of the distribution weighted by approximate particle area.

cs specific surface area, $\mathrm{m}^{2} / \mathrm{cc}$, assuming spherical particles.

sd standard deviation, but not in the statistical sense, according to D.W. Blankenship.

At the top right of the printout is a less useful summary box containing three columns, Dia, Vol\%, and Width. There should be at least one row of numbers in the table. There are more rows if the distribution appears to be multi-modal. For a unimodal distribution, Dia is the 50\% percentile particle size, Vol\% is the percentage of all particles contained within this distribution (100\% for unimodal), and Width is a measure of the width of the particle size distribution defined by (size of the $84^{\text {th }}$ percentile) - (size of the $16^{\text {th }}$ percentile). So the first printout that follows for SB2-1 SME product was interpreted by MicroTrac as having four modes. The two largest modes contain frit 200, while the two smallest contain sludge. The two starting sludges and three of the four SRAT products were characterized by bimodal distributions. The exception was the SRAT product from the run with $290 \%$ acid, where the larger sludge particles appear to have been attrited to the point where MicroTrac saw it as unimodal. 
WSRC-TR-2001-00051

Page 40 of 53

\section{Nominal Tank 8/40 Blend Run SB2-1 SME Product}

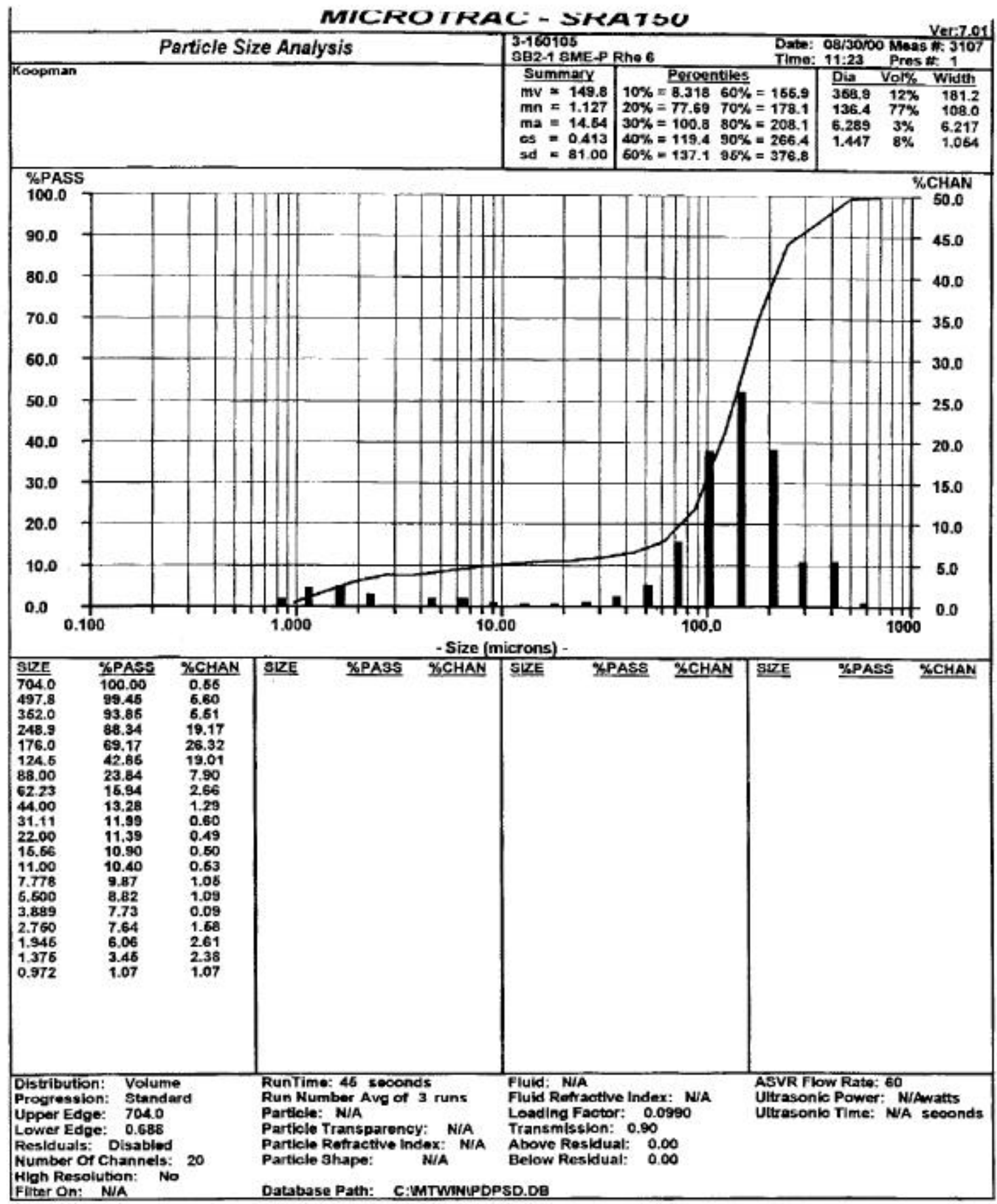


WSRC-TR-2001-00051

Page 41 of 53

Nominal Tank 40 Run SB2-2 SME Product

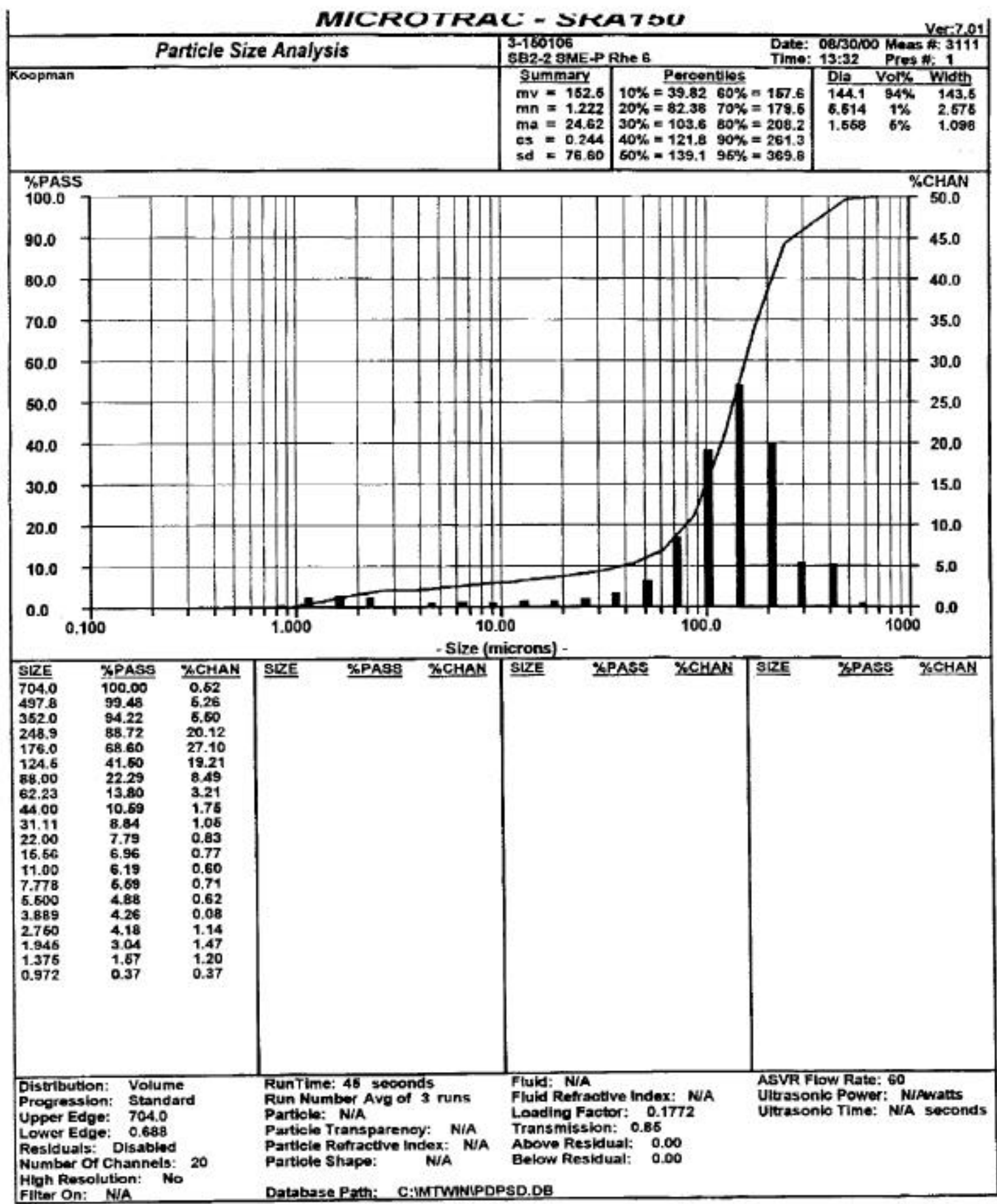


WSRC-TR-2001-00051

Page 42 of 53

Tank 8/40 Blend Run SB2-3 SME Product with HM Concentrations of Noble Metals

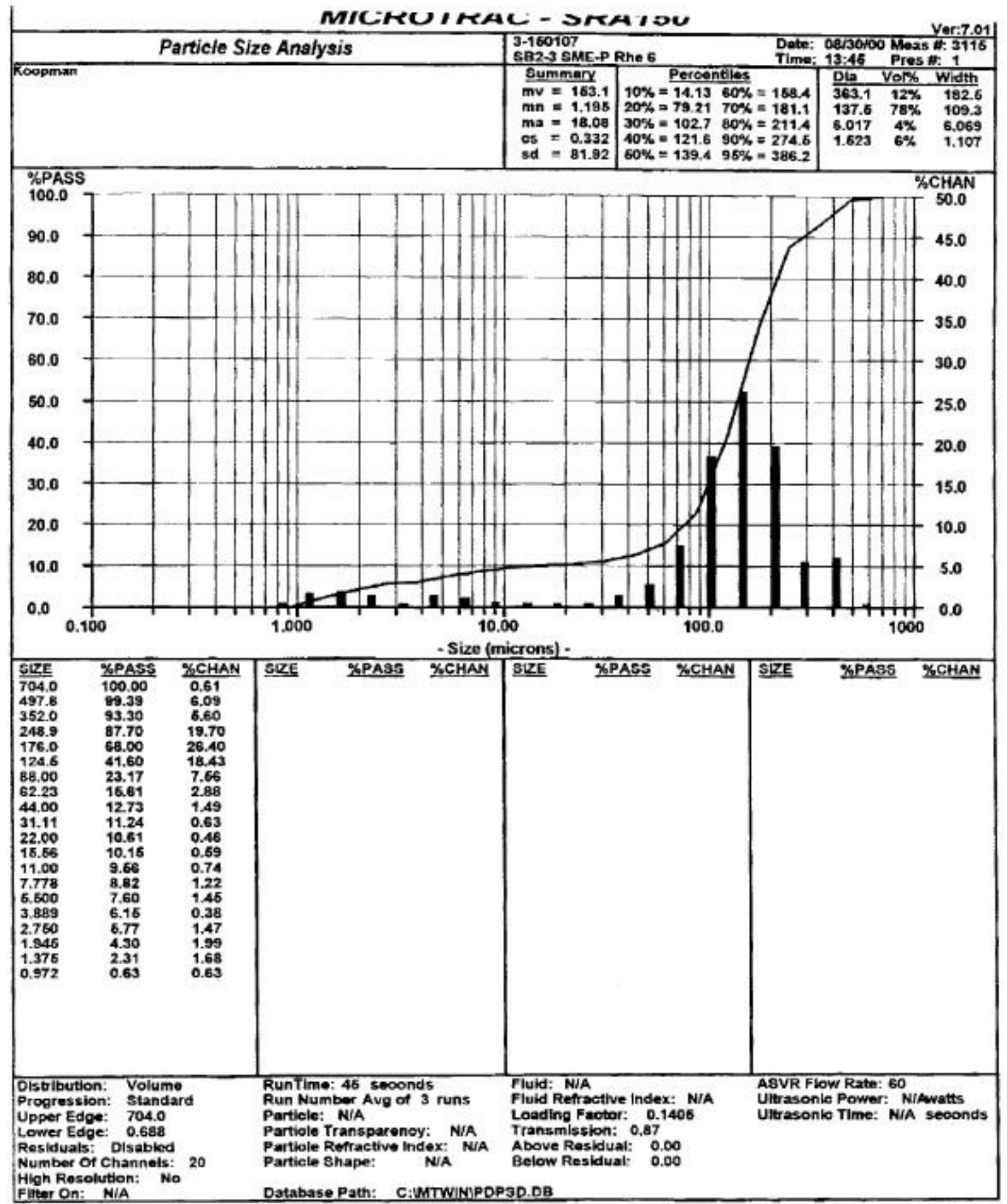


WSRC-TR-2001-00051

Page 43 of 53

Tank 8/40 Blend Run SB2-4 SME Product with 290\% Acid Stoichiometry

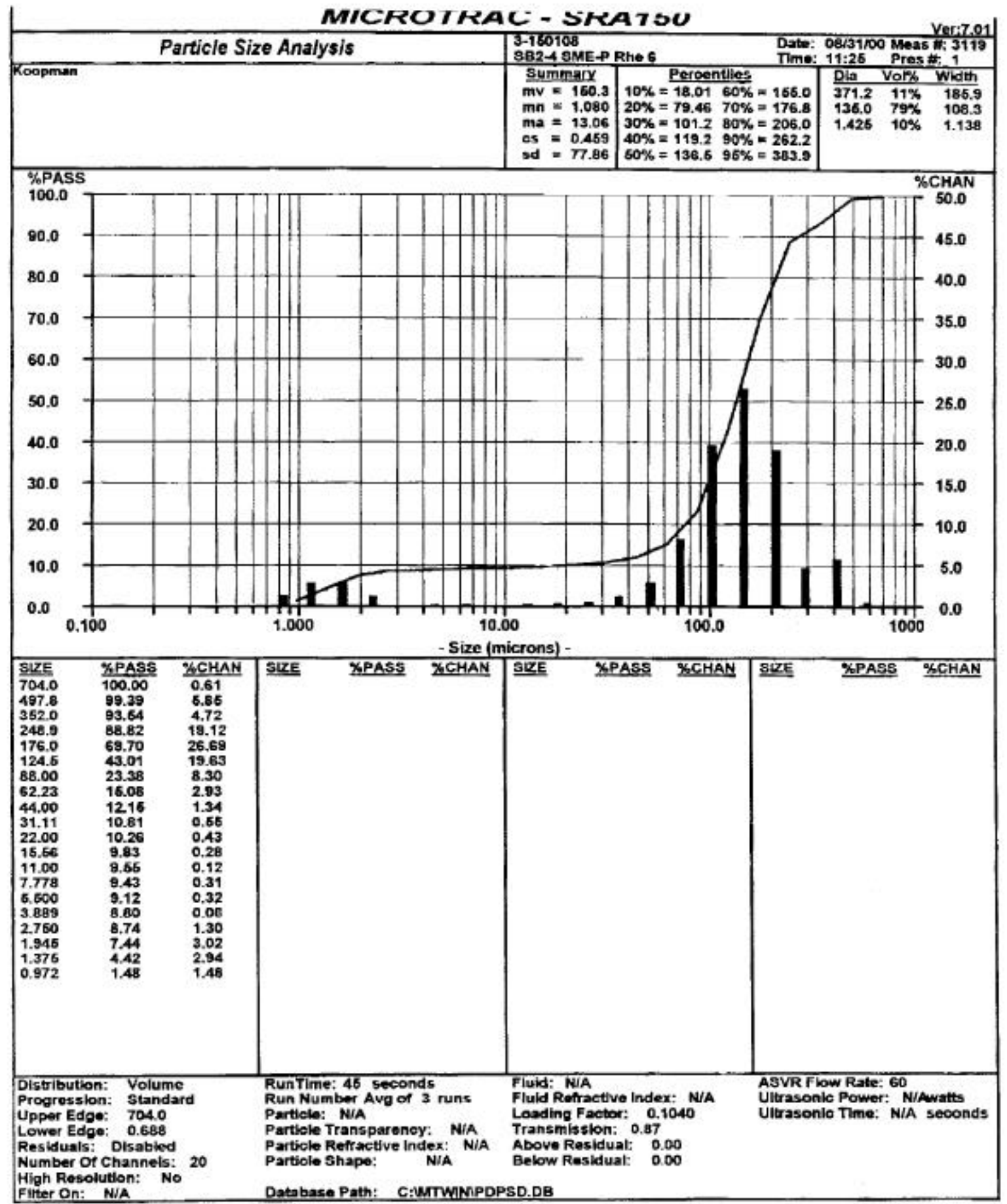


WSRC-TR-2001-00051

Page 44 of 53

\section{Nominal Tank 8/40 Blend Run SB2-1 SRAT Product}

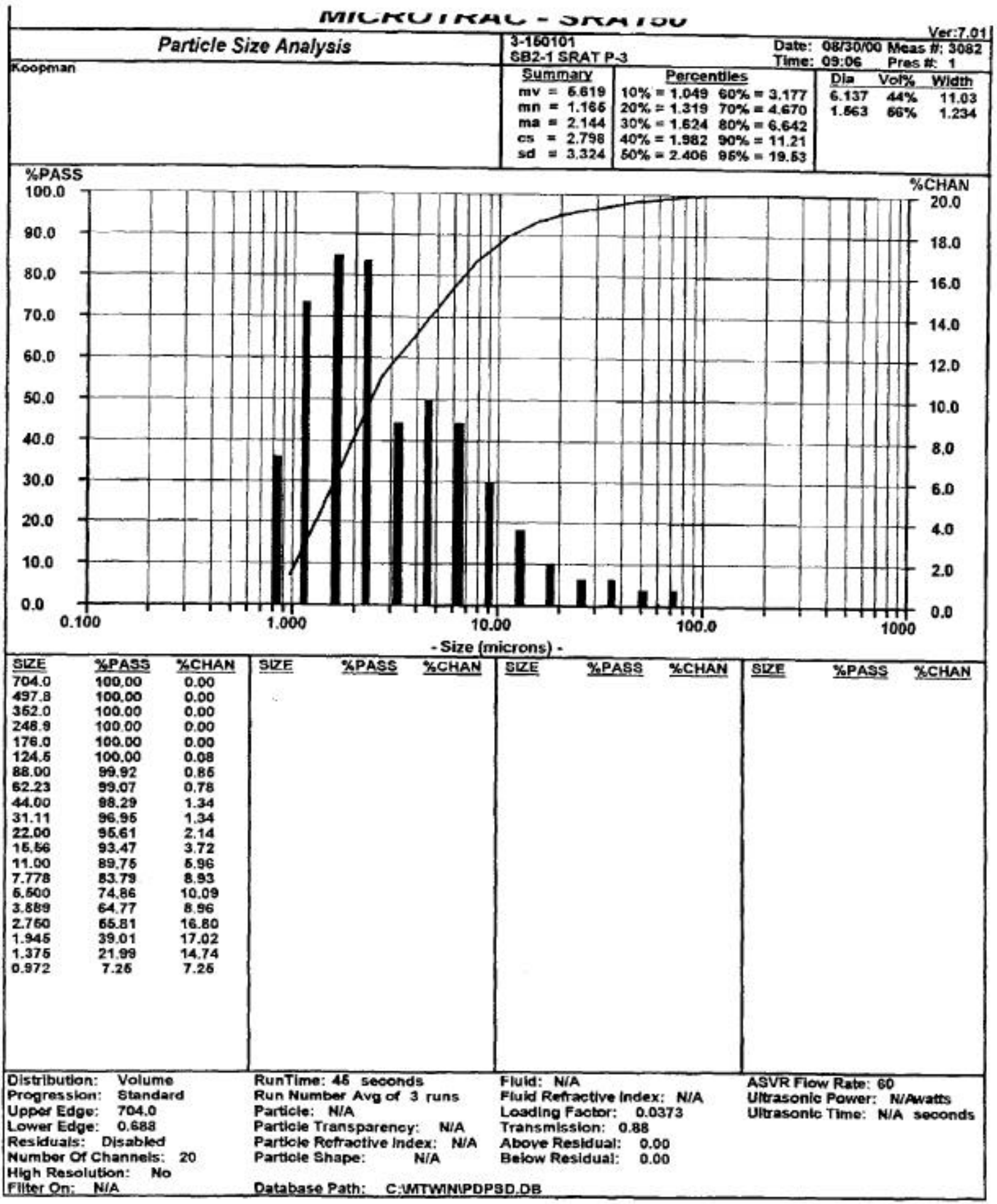


WSRC-TR-2001-00051

Page 45 of 53

Tank 40 Blend Run SB2-2 SRAT Product

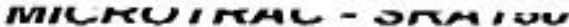

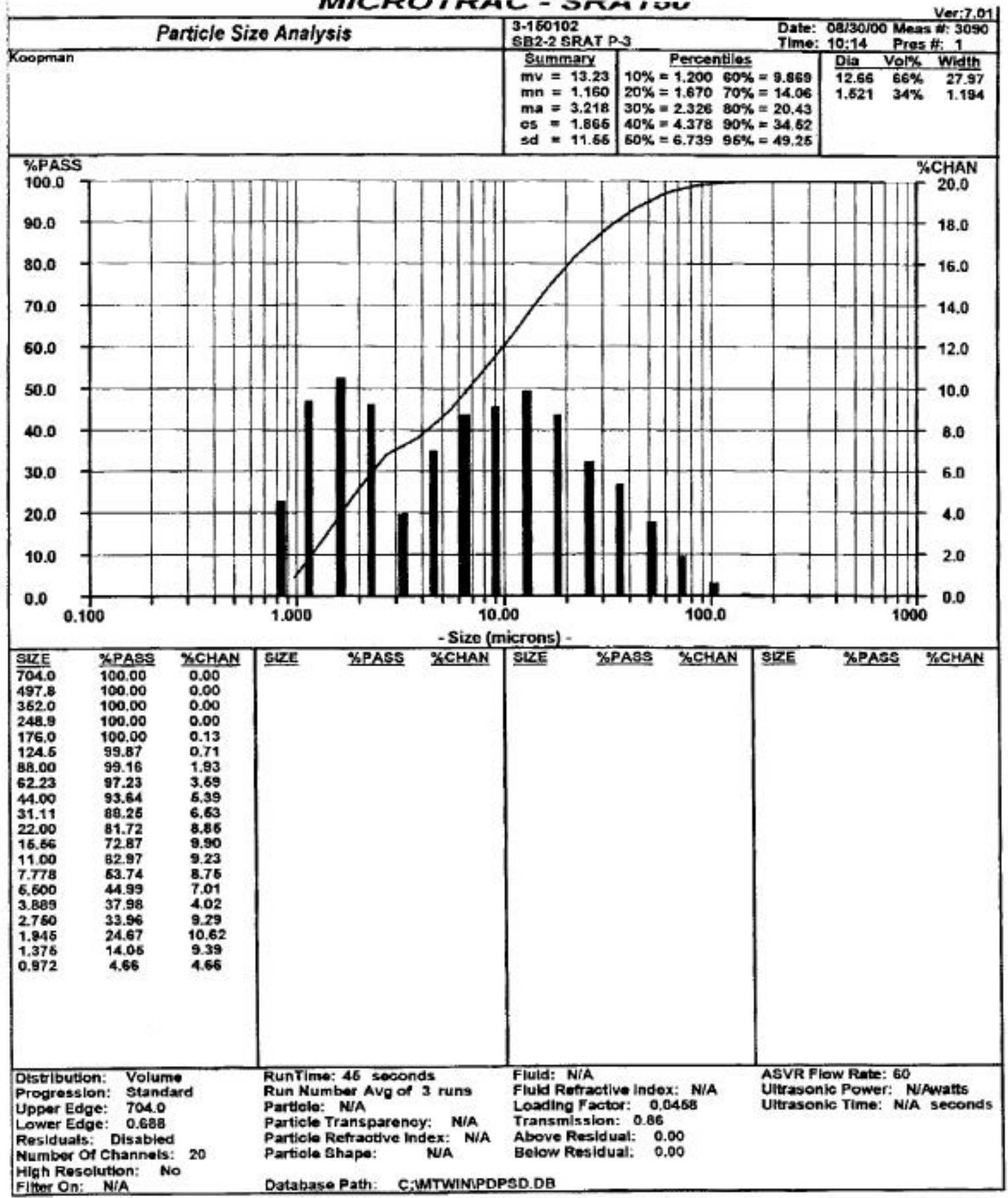


WSRC-TR-2001-00051

Page 46 of 53

Tank 8/40 Blend Run SB2-3 SRAT Product with HM Concentrations of Noble Metals

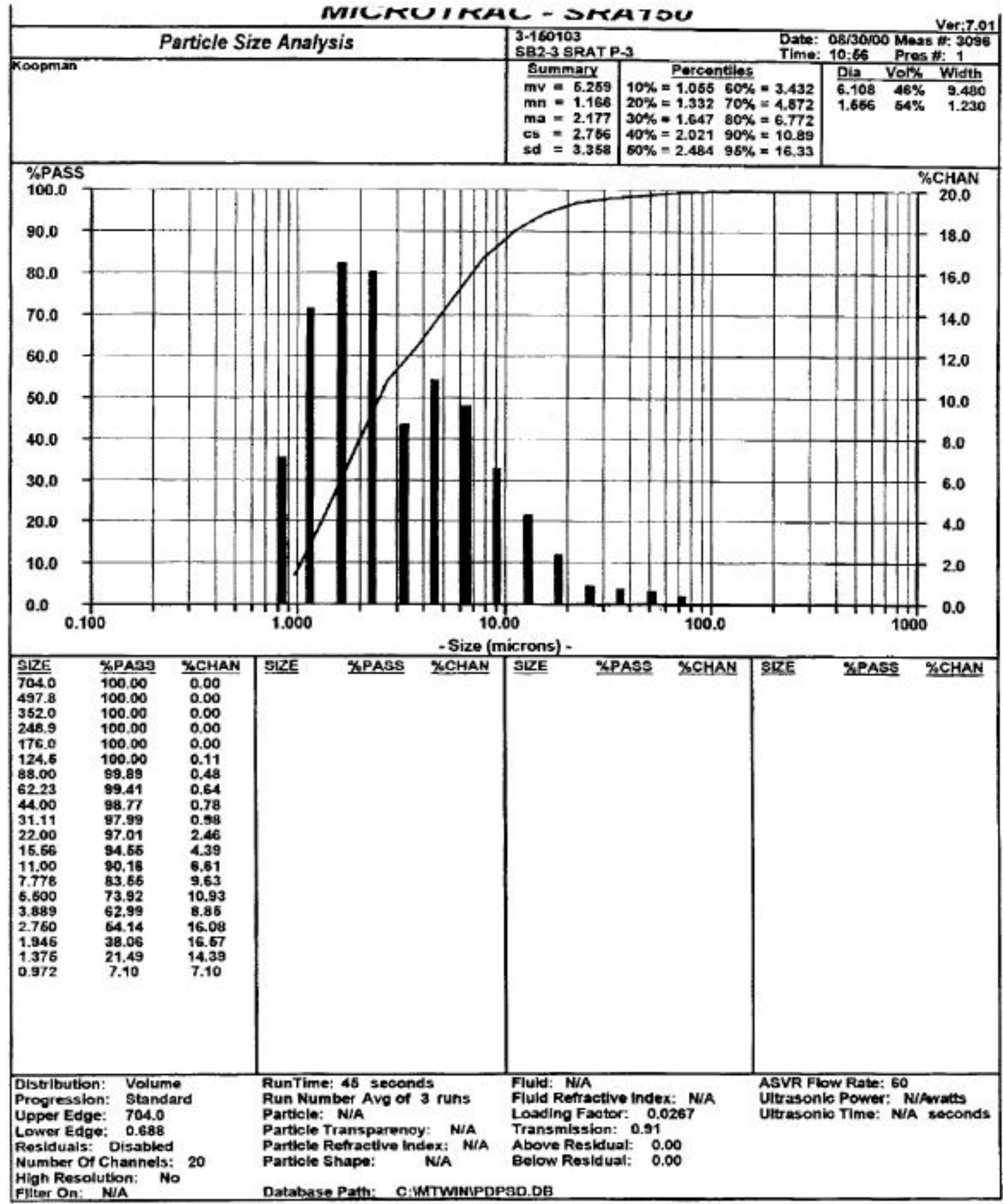


WSRC-TR-2001-00051

Page 47 of 53

Tank 8/40 Blend Run SB2-4 SRAT Product with $290 \%$ Acid Stoichiometry

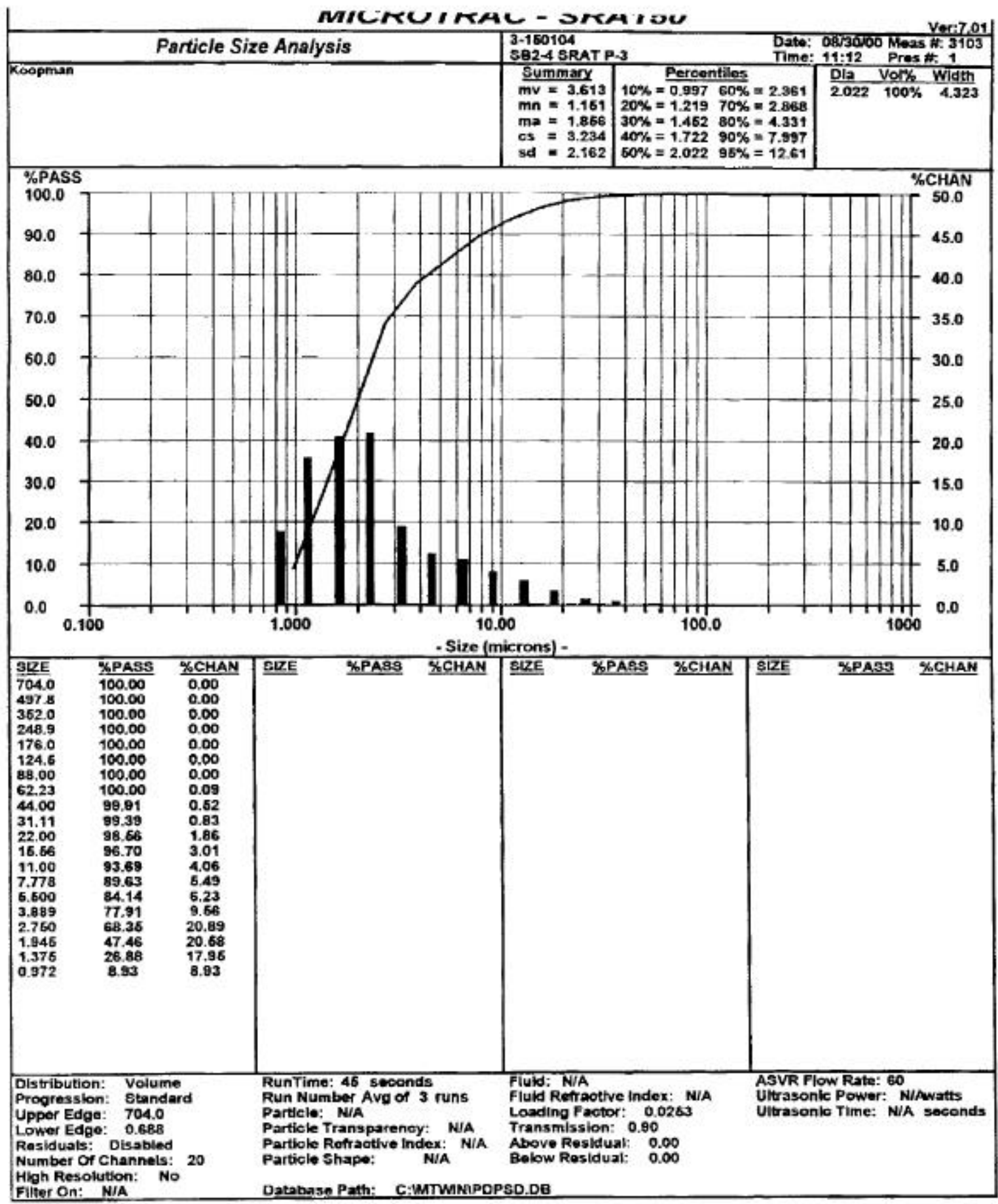


WSRC-TR-2001-00051

Page 48 of 53

Nominal Tank 8/40 Blend Sludge Simulant

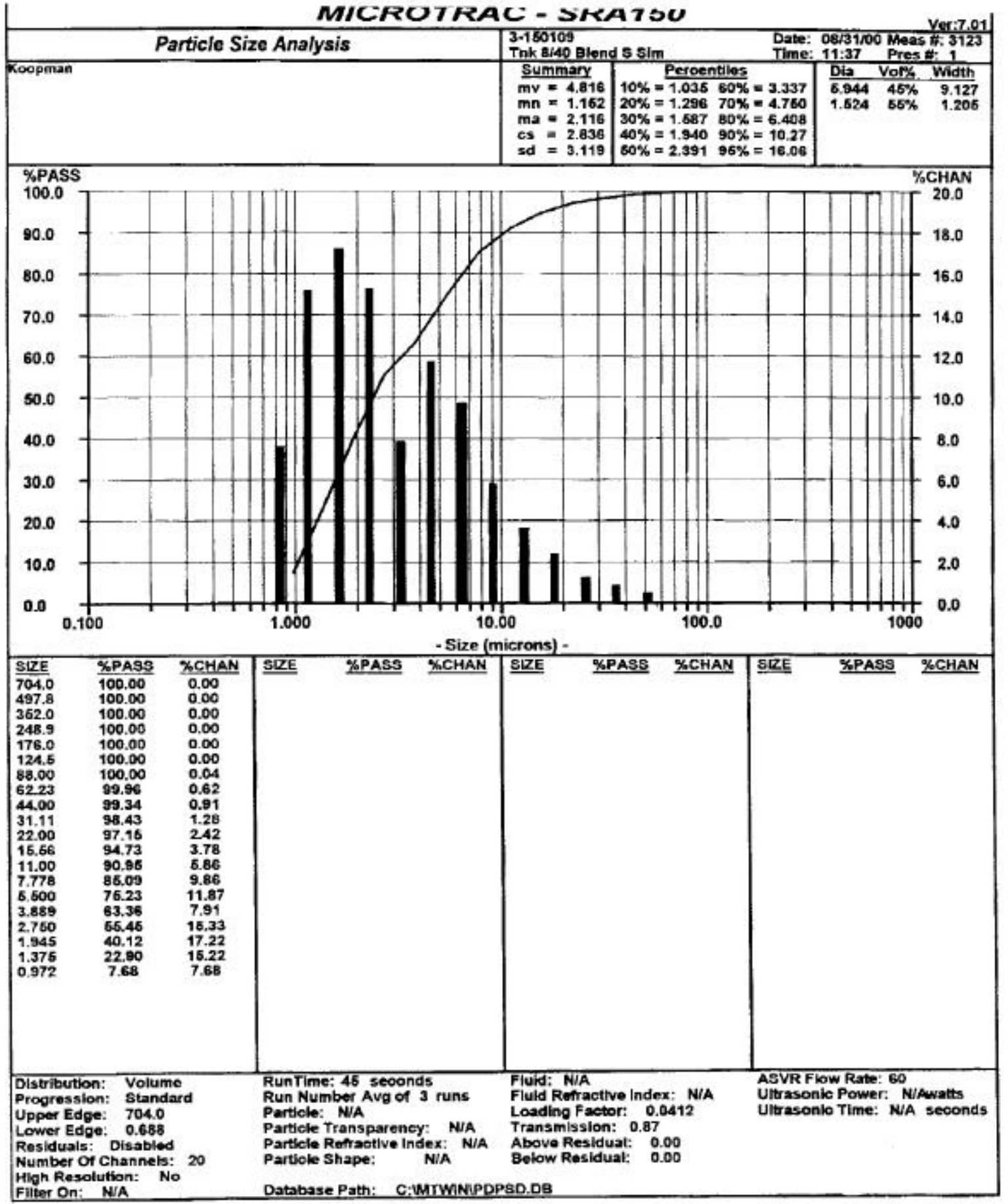


WSRC-TR-2001-00051

Page 49 of 53

Tank 40 Sludge Simulant after Nickel and Manganese Trim

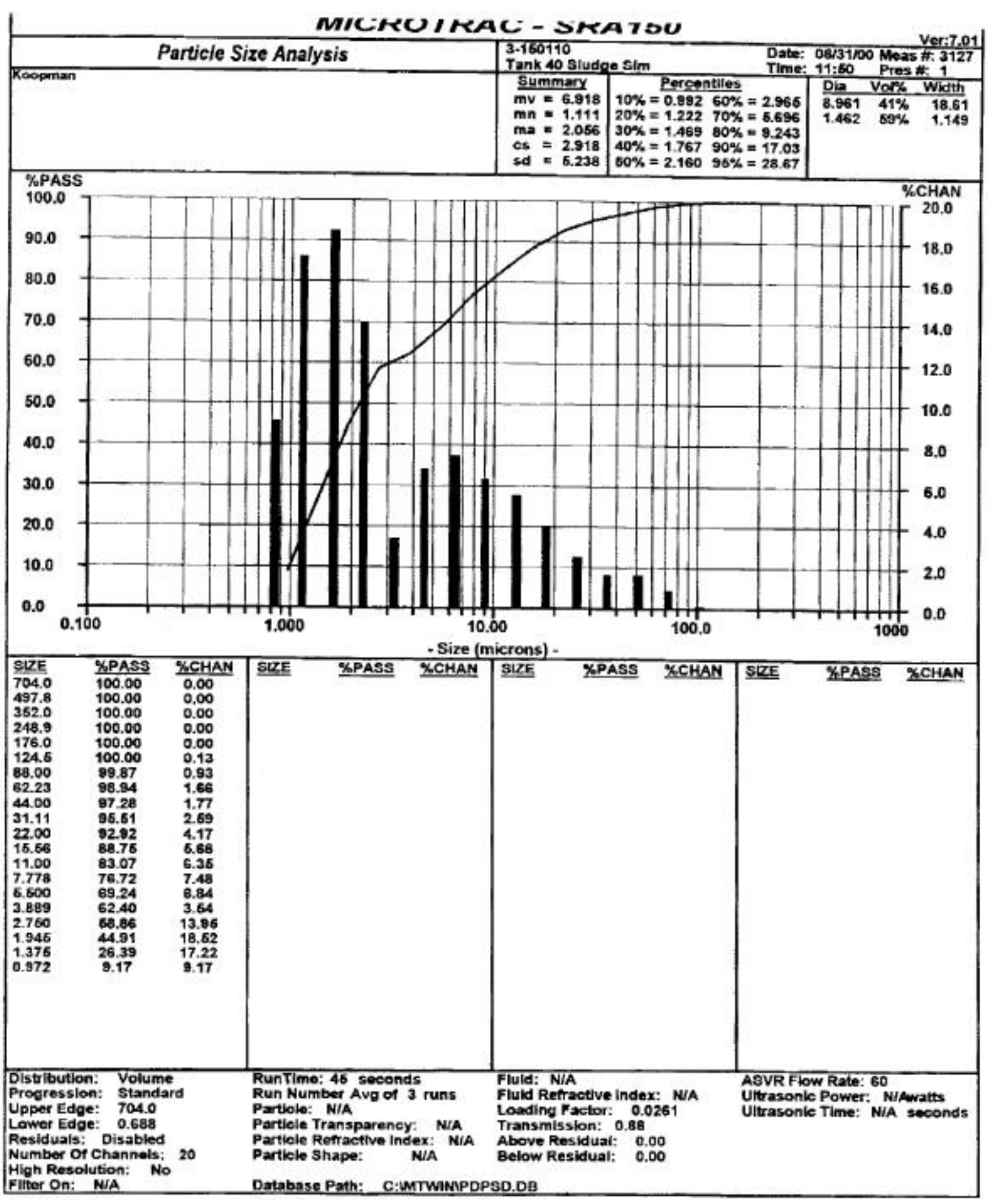


WSRC-TR-2001-00051

Page 50 of 53

Tank 40 Sludge Simulant before Nickel and Manganese Trim

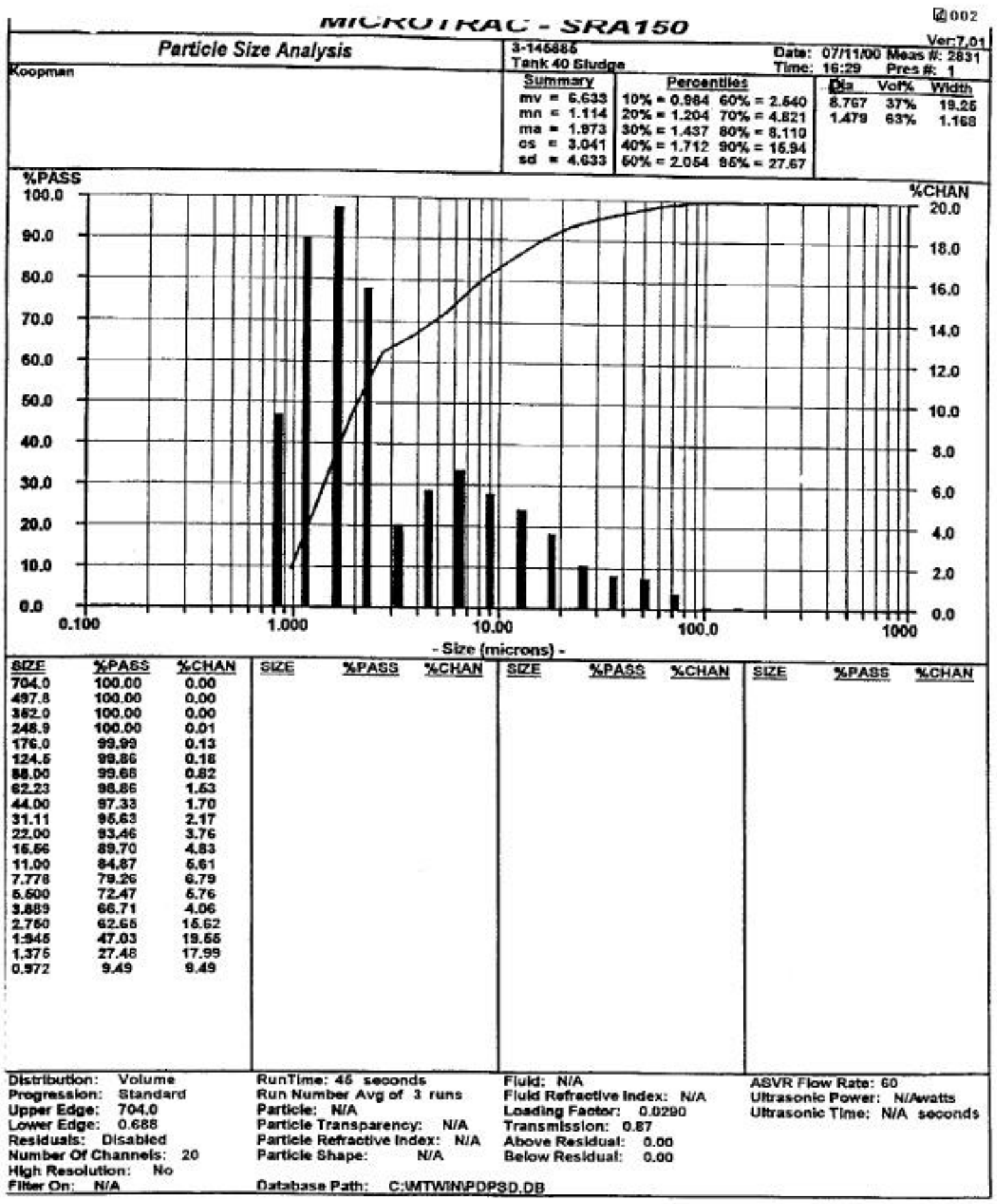


WSRC-TR-2001-00051

Page 51 of 53

The particle size distribution data provided some insight into what was happening during the SRAT/SME processing. Figure 27 shows the distribution for Tank 8/40 blend starting sludge plotted along with the distributions for SRAT products from the nominal run and the fairly similar run with HM levels of noble metals. Also plotted on this figure are a portion of the SME product scans for these two runs. An attempt has been made to mathematically subtract off the contribution of frit 200 to the SME product particle size distribution and then renormalize the sludge contribution to $100 \%$. Inaccuracies (small difference of large numbers) dominate in the two corrected SME product distributions from about 40 microns on up (marked with a dashed line in the figure).

Figure 27. Composite Tank 8/40 Blend Particle Size Distributions

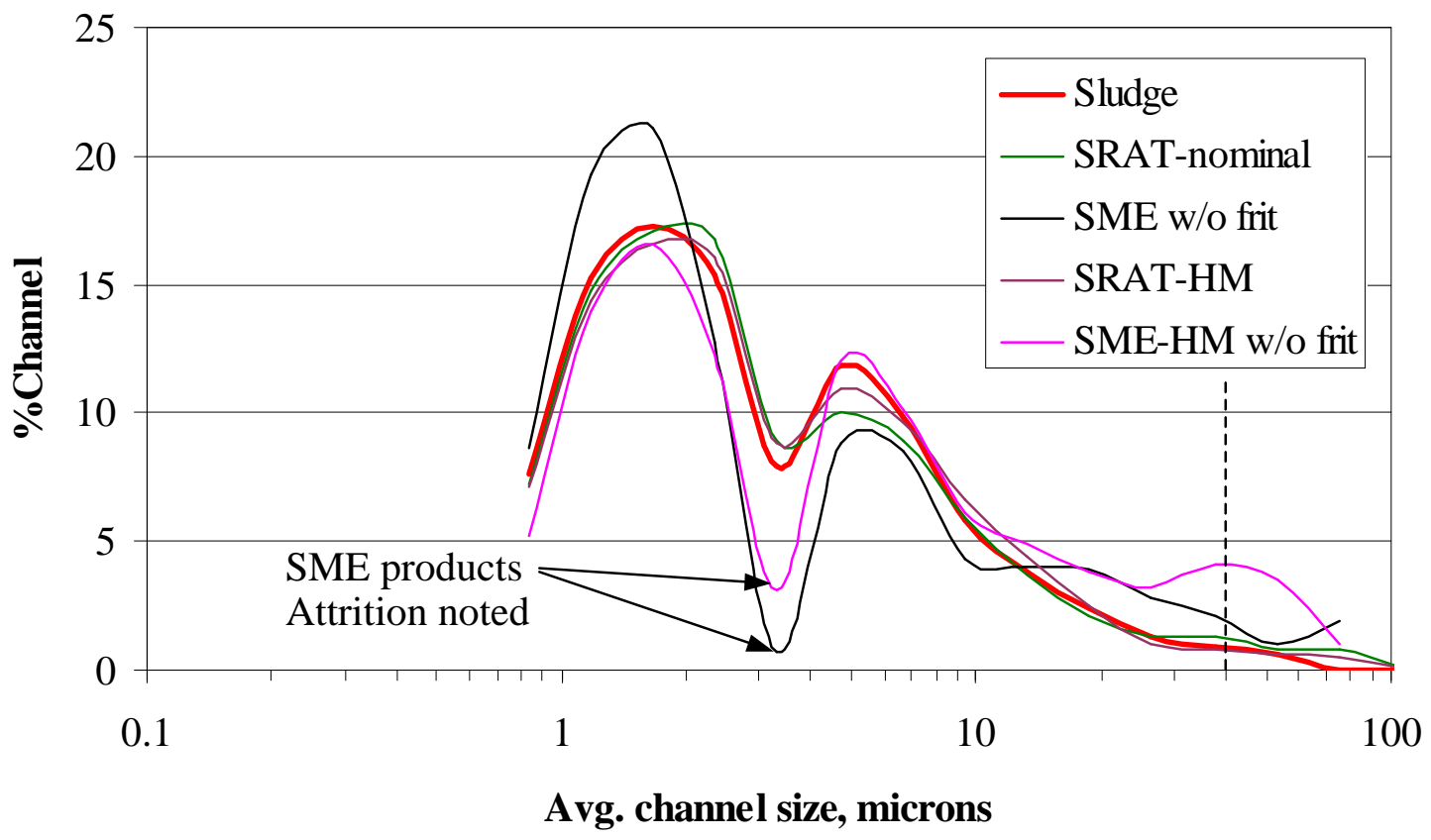

The SRAT product particle sizes appear to be very similar to the starting sludge. If there was a significant reduction in insoluble solids mass, then it must have been fairly uniformly distributed over the starting particles. There does appear to have been some attrition of particles in the 3-4 micron range in the SME products however. The run with worst case noble metals and $290 \%$ acid stoichiometry (SB2-4) shows considerably different behavior as seen below. 
WSRC-TR-2001-00051

Page 52 of 53

Figure 28. Worst Case Tank 8/40 Blend Particle Size Distributions

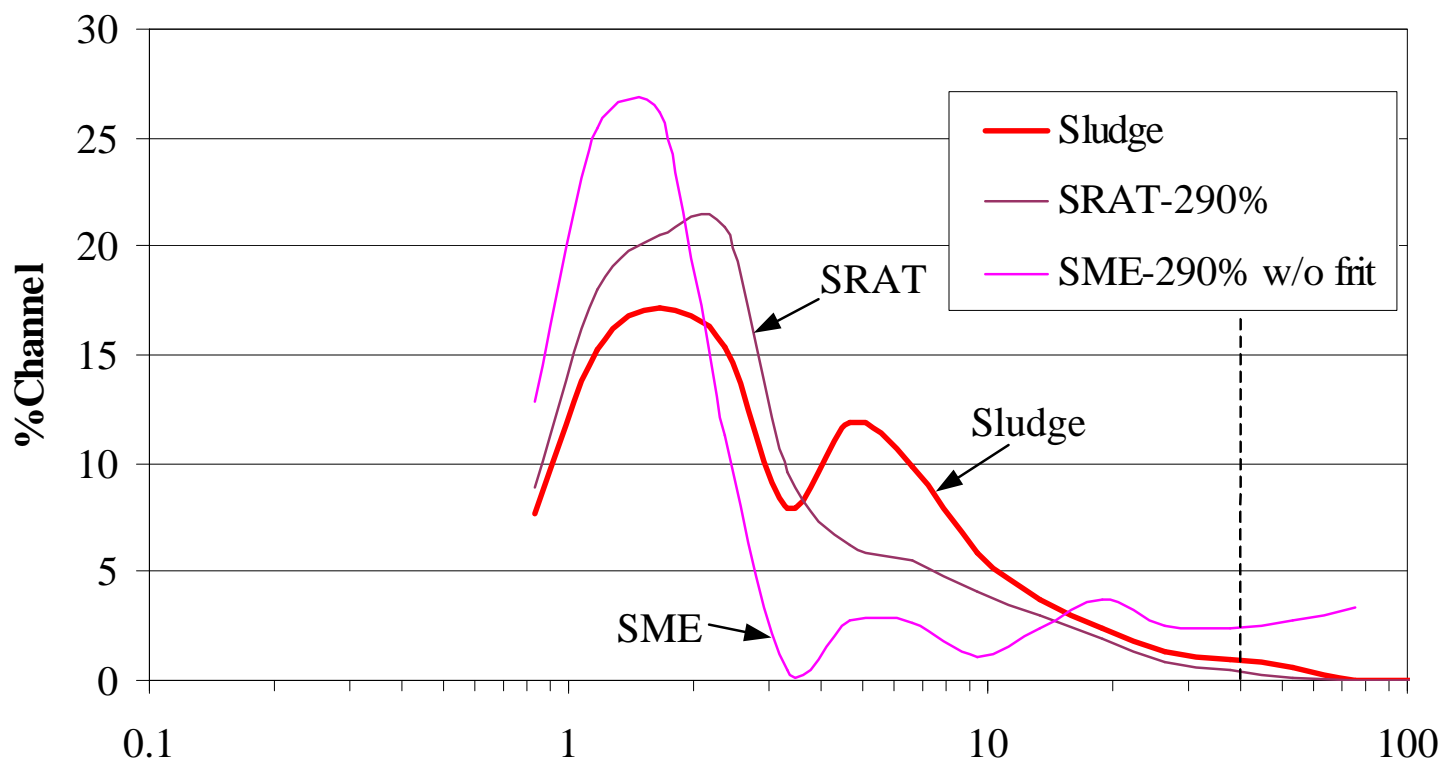

Avg. channel size, microns

The secondary peak in the sludge distribution at about 5 microns appears to have been attacked and perhaps 50-75\% destroyed (dissolved, broken up, etc.). The particles at about 3.5 microns, that were significantly attacked in the two $125 \%$ acid cases above, appear to have been nearly totally destroyed in the worst case (290\% acid). The increase in "\%Channel" between 1 and 3 microns (going from sludge to SRAT product to SME product) is probably due primarily to the fact that the 15 channels shown must sum to $100 \%$. Since another portion of the particle size distribution has been "lost", the remaining channel percentages are increased to represent a proportionately greater fraction of the $100 \%$. There was some confirmation of increased dissolution in the SB2-4 SRAT product data compared to SB2-1 based on the soluble solids determinations (6.5\% vs.5.2\%), but not in the SME product data. Overall, the available data does not justify excluding any of the hypotheses for explaining these particle size distribution shifts.

It would be interesting to be able to remove the internal normalization of the instrument. This would permit a calculation of the absolute number of particles per channel per unit mass of the starting slurry. Additional data beyond the particle size distribution would be needed, however, to legitimately renormalize the curves to an "absolute number of particles" basis. Nevertheless, this would be a prerequisite to concluding whether the mass of particles in the 1-3 micron range increased, decreased, or remained constant in number.

A high percentage of the starting sludge insoluble solids are apparently still present as insoluble solids at the end of the SME cycle. This constrains the degree to which a SRAT or SME product particle size distribution could be shifted upwards or downwards by a renormalization. My opinion is that any renormalization that changed the area under the particle size distribution curve between 0.7 and 40 microns by more than a factor of two relative to starting sludge would 
WSRC-TR-2001-00051

Page 53 of 53

be unreasonable (the distribution curve is on a volume basis, so this integral would be proportional to insoluble solids mass). It could be argued that even a change by a factor of 1.5 was extremely unlikely.

Consequently, it is much easier to identify SRAT and SME product size ranges that appear to have lost particles. An example is "SME-290\%" at 3.5 microns, where no feasible renormalization relative to the starting sludge could increase that channel by the two orders of magnitude needed to match the starting sludge.

Figure 29 shows data for the Tank 40 sludge trimmed with nickel and manganese along with the corresponding SRAT and SME product data.

Figure 29. Mn and Ni Trimmed Tank 40 Particle Size Distribution Data

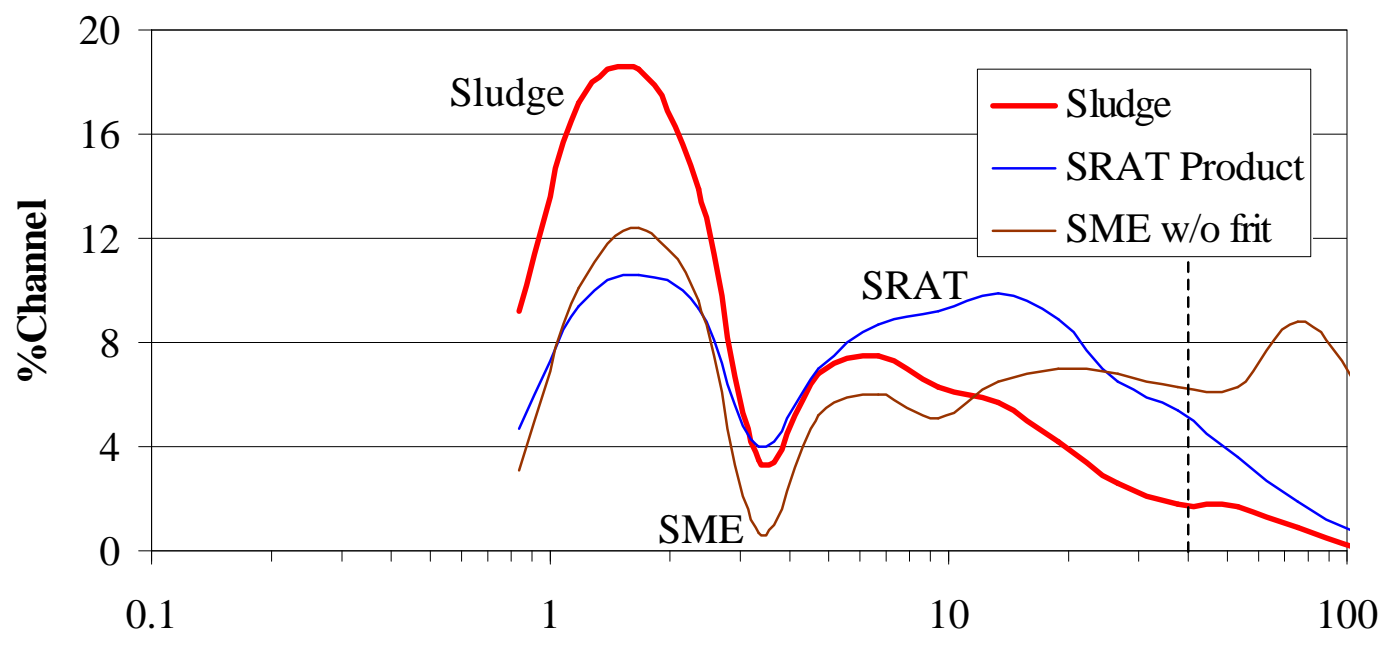

Avg. channel size, microns

The interpretation is difficult. The data may suggest that particles have agglomerated during SRAT processing. Thus, more particles are present in the 5-30 micron range and fewer particles are present in the 0.7-4 micron range of the SRAT product. The SME product appears to be similar to the SRAT product in this regard. It is possible that this shift was partly or totally responsible for the convergence of the viscosities of the Tank 8/40 blend and Tank 40 SRAT and SME products in spite of the initially large differences between the two starting sludges. The basis for this conclusion includes consideration of the fact that colloidal size particles (less than several microns in diameter) have a much greater impact on viscosity than larger particles. 
W. D. Kerley, 704-S

M. A. Rios-Armstrong, 704-27S

J. F. Ortaldo, 704-S

R. E. Edwards, 704-25S

J. E. Occhipinti, 704-27S

R. S. Beck, 704-28S

L. M. Papouchado, 773-A

E. W. Holtzscheiter, 773-A

R. H. Spires, 773-A

N. E. Bibler, 773-A

C. M. Jantzen, 773-A

S. L. Marra, 704-1T

C. T. Randall, 773-42A

D. A. Crowley, 773-43A

T. L. Fellinger, 773-A

D. P. Lambert, 704-1T

R. E. Eibling, 704-1T

E. K. Hansen, 704-1T

D. W. Blankenship, 773-41A

D. C. Koopman, 704-1T

STI, 703-43A (4) 